\title{
Predictors and prognostic value of blood pressure level and variation in acute stroke
}

Citation for published version (APA):

Boreas, A. M. H. P. (2001). Predictors and prognostic value of blood pressure level and variation in acute stroke. [Doctoral Thesis, Maastricht University]. Universiteit Maastricht. https://doi.org/10.26481/dis.20010531ab

Document status and date:

Published: 01/01/2001

DOI:

10.26481/dis.20010531ab

Document Version:

Publisher's PDF, also known as Version of record

\section{Please check the document version of this publication:}

- A submitted manuscript is the version of the article upon submission and before peer-review. There can be important differences between the submitted version and the official published version of record.

People interested in the research are advised to contact the author for the final version of the publication, or visit the DOI to the publisher's website.

- The final author version and the galley proof are versions of the publication after peer review.

- The final published version features the final layout of the paper including the volume, issue and page numbers.

Link to publication

\footnotetext{
General rights rights.

- You may freely distribute the URL identifying the publication in the public portal. please follow below link for the End User Agreement:

www.umlib.nl/taverne-license

Take down policy

If you believe that this document breaches copyright please contact us at:

repository@maastrichtuniversity.nl

providing details and we will investigate your claim.
}

Copyright and moral rights for the publications made accessible in the public portal are retained by the authors and/or other copyright owners and it is a condition of accessing publications that users recognise and abide by the legal requirements associated with these

- Users may download and print one copy of any publication from the public portal for the purpose of private study or research.

- You may not further distribute the material or use it for any profit-making activity or commercial gain

If the publication is distributed under the terms of Article $25 \mathrm{fa}$ of the Dutch Copyright Act, indicated by the "Taverne" license above, 
Predictors and prognostic value of blood pressure level and variation in acute stroke 
The publication of this thesis was financially supported by:

Boehringer Ingelheim BV, GlaxoSmithKline, Serono Benelux BV, Baxter BV.

Predictors and prognostic value of blood pressure level and variation in acute stroke. A.M.H.P. Boreas

Thesis Universiteit Maastricht

ISBN 90-9014779-9

O 2001, A.M.H.P. Boreas, Maastricht, The Netherlands

All rights are reserved, whether the whole or part of the material is concerned. No part of this publication may be reproduced, stored in a retrieval system, or transmitted in any form or by any means, electronic, mechanical, photocopying, recording or otherwise, without written permission from the copyright owner. 


\title{
Predictors and prognostic value of blood pressure level and variation in acute stroke
}

\author{
Proefschrift
}

ter verkrijging van de graad van doctor aan de Universiteit Maastricht, op gezag van de Rector Magnificus,

Prof. dr. A.C. Nieuwenhuijzen Kruseman volgens het besluit van het College van Decanen, in het openbaar te verdedigen op donderdag 31 mei 2001 om 14.00 uur

door

Anna Maria Hubertina Petronella Boreas 


\section{Promotores}

Prof. dr. J. Troost

Prof. dr. P.W. de Leeuw

\section{Co-promotor}

Dr. J. Lodder

\section{Beoordelingscommissie}

Prof. dr. J.L.H. Evers (voorzitter)

Prof. dr. P.M.W. Bath (University of Nottingham, UK)

Dr. A.H. van de Meiracker (Erasmus Universiteit Rotterdam)

Prof. dr. H.W.M. Steinbusch

Prof. dr. H.A.J. Struijker Boudier

This thesis was prepared at the Department of Neurology, University Hospital Maastricht, The Netherlands 
Knowledge is a process of piling up facts, wisdom lies in their simplification.

(Martin Fisher) 


\section{Contents}

General introduction

1. Introduction

2. Predictors of post-stroke blood pressure level and course

3. Prognostic value of blood pressure in acute stroke

4. Admission blood pressure in acute ischemic stroke: relationship with stroke subtype, and prognostic value

5. Continuous, automatic blood pressure monitoring within 24 hours after stroke: blood pressure levels and diurnal variations

6. Blood pressure level and diurnal variation do not predict stroke outcome

7. The insula has not a unique role in blood pressure control

8. General discussion

9. Summary

10. Samenvatting

Appendix

References

Dankwoord 


\section{General introduction}

Stroke is an important disease. In the Netherlands, there are approximately $30.000 \mathrm{new}$ strokes each year. ${ }^{1}$ Stroke ranks third at the list of death causes in Europe. ${ }^{1-6} \mathrm{It}$ is also one of the most prevalent causes of lasting disability, especially in the elderly. ..5 $^{-9.9}$ The cost of stroke is high: in the Netherlands the total yearly costs of stroke (medical and productivity losses) amount to 2500 million Dutch guilders. ${ }^{10}$ Furthermore, the social and psychological burden of stroke is enormous." ${ }^{12}$ With the expected relative and absolute increase of elderly people in Dutch society, the problem of stroke is likely to increase during the coming decades. Using a small number of simple assumptions, the current number of yearly strokes was rather reliably predicted almost ten years ago. ${ }^{13}$ The number of strokes increased despite the fact that various methods for primary or secondary stroke prevention following first stroke or TIA have been proven to be clinically effective, such as: treatment of hypertension, ${ }^{14}{ }^{15}$ anticoagulants in patients with atrial fibrillation, ${ }^{16-18}$ new anti-platelet drugs beside aspirin, ${ }^{19} 20$ such as dipyridamole ${ }^{21}$ and clopidogrel, ${ }^{22}$ and carotid endarterectomy in patients with high-grade internal carotid artery stenosis. ${ }^{23-25}$ New anti-platelet drug $5^{26} 27$ and statins ${ }^{28} 29$ are currently under clinical investigation to lower the chance of stroke, myocardial infarction, or vascular death following stroke. Besides secondary prevention, improvement of prognosis in stroke patients could come from acute stroke interventions. For the time being, however, this seems only a theoretical possibility, as none of the so-called neuroprotective drugs were proven to be successful in clinical trials. ${ }^{6}$ Another acute stroke intervention, which has gained clinical acceptance is thrombolysis, which lowers the risk of death or unfavourable functional outcome with approximately 30 $\%{ }^{30-33}$ However, for various reasons only a small minority of five to ten percent of all ischemic stroke patients will be eligible for this therapy. ${ }^{34}$ Concepts on early neuroprotective interventions which may ultimately be more successful, continue to be developed and tested further. Among these are lowering of body temperature, ${ }^{33}$ 35-37 optimising oxygen saturation,,$^{35}$ normalising blood sugar, ${ }^{33} 35$ inhibiting nitrogen monoxide (NO) production, ${ }^{39}$ and increasing central GABA activity. ${ }^{40}$

An additional possibility to improve prognosis following stroke may be achieved by manipulating the level of blood pressure (BP) in acute stroke. There may seem a pathophysiological rationale for this, but current data conditional for clinical testing of this possibility are thin. One of the problems on the approach of blood pressure manipulation is that BP level may largely vary among stroke patients, and may depend on various factors. Therefore, a pragmatically desirable approach of a simple, uniform blood pressure treatment modality in acute stroke may be elusive; it may be beneficial to increase BP in some patients, decrease it in others, and leave it as it is in possibly even most of them. What BP values should be treated, and what BP level to aim at in such treatment remains currently enigmatic. Besides, there is a real danger should BP be treated in a uniform manner, regardless its level or without accounting for other relevant conditions. This consideration relates to the concept of cerebral autoregulation, which implies that under normal conditions regional cerebral blood flow is kept constant over a certain range of systemic BP. ${ }^{42}$ In stroke, this mechanism is lost, 
and cerebral perfusion pressure becomes directly BP dependent. ${ }^{42-45}$ At high BP levels, the brain is no longer protected from the effects of extreme pressure in the capillary system. This may result in edema formation and local hemorrhages, which further threatens local blood supply with ultimately destruction of cerebral tissue. ${ }^{4346}{ }^{47}$ On the other end of the spectrum, low systemic BP can not be compensated for, and local perfusion pressure drops below the critical level to meet tissue demand of oxygen and glucose, which will eventually also compromise tissue viability. ${ }^{41}{ }^{42}{ }^{47.52}$ How much cerebral autoregulation is disarranged may depend on various factors, such as preexisting BP level, any antihypertension treatment, site and size of the infarct, and concommitant factors, especially diabetes mellitus as this is known to affect autoregulation. ${ }^{42}$

So far, little is known about what factors independently predict the level of BP in acute stroke or its decline, or what BP characteristics are independent predictors of stroke outcome. Before any clinical trial on BP treatment in acute stroke would be able to carefully manoeuvre between the Scylla of local cerebral hyperperfusion and Charibdys of hypoperfusion, more robust data on these issues are required. The present study was set out to explore (retrospectively) and investigate (prospectively) factors related to BP level and course in acute stroke, and various BP characteristics as independent predictors of stroke outcome at six months. 
1

\section{Introduction}

Adapted from:

Boreas AMHP, Lodder J. Bloeddruk-behandeling in de acute fase van het ischemisch CVA. Ned Tijdschr Neurol 2000;6:395-399. 


\section{Blood pressure course in the acute phase of ischemic stroke}

Blood pressure (BP) is elevated in 70 to $94 \%$ of acute stroke patients. ${ }^{53-58}$ The highest BP values after stroke are found in patients with primary intracerebral hemorrhage, patients of black ethnic origin or patients known with hypertension before stroke. ${ }^{4753545859}$ The initially elevated BP spontaneously goes down during the first week, ${ }^{545860}$ with the greatest decline during the first four days. ${ }^{54} 5861-63$ The magnitude of decline relates to the level of BP: the higher the initial BP, the greater the decline. ${ }^{4245546465} \mathrm{Up}$ to $64 \%$ of the patients have regained prior BP level on the second day following stroke. ${ }^{55} \mathrm{BP}$ then gradually further declines in the first week after stroke. ${ }^{55}$ In about $30 \%$ of the stroke patients BP remains elevated one week after stroke occurrence. ${ }^{41}{ }^{44} 53$ In patients known with hypertension before stroke, BP is higher than in patients without hypertension, ${ }^{66}$ whereas BP remains higher after the acute stroke phase. ${ }^{67}{ }^{68}$ Controls showed a similar BP course after hospital admission, but the BP level was lower than in stroke patients. ${ }^{54}$ Britton et al. stated this might represent pre-existing higher BP in stroke patients as compared with the controls. ${ }^{54}$ They thought it also probable that a specific physiological response to the brain damage in stroke added to the stress of acute illness and hospitalization as seen in all patients.

\section{Admission blood pressure and prognosis}

The mechanism of BP elevation in the acute phase of stroke is still unclear: acute BP elevation may be the cause of stroke in some cases, a result of the stroke, or an epiphenomenon associated with the stroke process. ${ }^{69}$ Ideas on how BP in acute stroke may influence stroke prognosis relate to the concept of the so-called penumbra: a certain tissue volume surrounding the necrotic core, where perfusion is too low to maintain normal neuronal function, but sufficient enough to keep the neurons alive for a short period of time. Under normal physiological circumstances, cerebral blood flow (CBF) is regulated according to the relationship between cerebral perfusion pressure (CPP) and cerebrovascular resistance (CVR): $\mathrm{CBF}=\mathrm{CPP}: \mathrm{CVR}$. CPP represents the difference between arterial pressure forcing blood into the cerebral circulation and venous pressure. Under normal conditions, venous pressure is negligible and CPP is equal to arterial BP. Under conditions of normal CPP, changes in $\mathrm{CBF}$ follow changes in CVR. Because of vasoparalysis in the acute phase of stroke, the mechanism of adapting CVR fails, and blood flow in the ischemic penumbra is directly pressure dependent. ${ }^{42-45}$ One could postulate that, initially, elevated BP may be beneficial in increasing blood flow in the ischemic penumbra, and could be regarded as a physiological compensatory mechanism for impaired cerebral perfusion pressure. ${ }^{475268}$ However, sustained elevation of BP may be harmful since it may lead to cerebral edema and trigger hemorrhagic transformation of the infarct, ${ }^{4346}$ which may lead to further tissue destruction. ${ }^{47}$ In the absence of autoregulatory mechanisms, low BP after stroke may directly lead to impaired local perfusion pressure with consequent further anoxic 
cerebral damage. ${ }^{4142} 47.52$ Based on these considerations it can be assumed that the BP level early after stroke may influence outcome, but that this may in turn depend on various conditions, such as size and time course of the penumbra, for example.

Data on prognostic significance of BP levels following acute stroke are conflicting: some studies showed no relationship between admission BP and outcome, ${ }^{46} 70.73$ others reported high ${ }^{42} 485074.76$ or low ${ }^{n}$ admission BP to be associated with poor outcome. Differences in study design may explain some of the conflicting findings: some reports only studied patients with cerebral hemorrhage ${ }^{50}$ or mixed series with hemorrhages and infarcts ${ }^{48}$ or even TIA's. ${ }^{46}$ Some included patients more than a week after the acute event, ${ }^{465} \mathrm{n}$ which is likely beyond the period of any impact of BP level on tissue salvage or further destruction. Finally, studies differ in the way BP was recorded. ${ }^{48}$ In studies which only used one admission BP value, the admission time after stroke onset varied widely. ${ }^{75}$ From the point of possible manipulation of early BP to improve outcome, studies that included patients within 3 or 6 hours following stroke may be most relevant. It may look ideal to study BP recorded by an automatic BP monitoring device, but one should realize that in real life admission BP is measured 'by hand' on hospital arrival in most cases. Pragmatically, therefore, studies that analyse admission BP measured 'by hand' should not be considered of little value, on the contrary. However, various other aspects may more reliably be measured by automatic monitoring devices, such as 24-hour BP course.

\section{4-hour blood pressure monitoring}

Automatic 24-hour BP monitoring (ABPM) reduces the measurement variability and observer bias compared to casually recorded BP, and provides additional information about day-night changes in BP. ${ }^{48} 59$ Lip et al. showed that the first casually recorded admission BP was similar to the first 24-hour measured ABPM value, whereas the first admission BP value was higher than the mean 24-hour ABPM value. ${ }^{59}$

It is well known that there is a diurnal pattern of BP change in normotensive persons, with morning values being higher than those recorded in the evening and with a further decrease during nighttime. ${ }^{78-83}$ This decrease in nighttime BP level is called 'dipping'. A number of definitions have been used to define dipping, including an arbitrarily chosen absolute fall of $10 \mathrm{mmHg}$ or more between day and night systolic or diastolic BP, or a decrease of $10 \%$ or more in systolic or diastolic BP between day and night. ${ }^{84-86}$ In hypertensive patients the nocturnal dip is reduced. ${ }^{87}{ }^{88}$ Patients who lose this diurnal variation ('nondippers') have an increased risk of hypertensive target organ damage. ${ }^{86}{ }^{89}$ Most patients with a stroke have elevated 24-hour BP levels, with a reduced nocturnal BP fall. ${ }^{59} 81869091$ Patients with an intracerebral hemorrhage sometimes even have higher BP values during the night than during the day ('reversedippers'). ${ }^{59}$

The degree of BP variation after ischemic stroke may be related to stroke subtype and lesion site. ${ }^{86}$ Some studies reported that especially lacunar infarcts were associated 
with diminished BP variation. ${ }^{88} 90$ Dawson et al. found that diurnal systolic BP change was significantly reduced in patients with cortical infarcts and primary intracerebral hemorrhages in contrast to patients with subcortical infarcts, whereas diurnal diastolic BP was significantly reduced in all three subgroups. ${ }^{86}$ Sander et al. observed a greater reduction in diurnal BP variation after thromboembolic infarction than after hemodynamic infarction and found that patients with insular infarction had a reduced or even abolished circadian BP variation. ${ }^{91}{ }^{92}$ Yamamoto et al. adressed the diminished nocturnal BP decline to lesion site: injury to the striatum, diencephalon, midbrain and pontine tegmentum and their connecting fibers led to a diminished BP fall at night. ${ }^{93}$ However, most of these studies used small patient groups, ${ }^{949}$ or included patients later than 24 hours after stroke onset. ${ }^{53} 929397$ Furthermore, for analyses all day- and nighttime hours were joined together, ${ }^{59} 698692-9498-100$ not leaving out the hours during which the BP transition between the nocturnal and diurnal period is assumed to occur. ${ }^{12}$ Including the BP transition values is likely to blunt any contrast between daytime and nighttime values and its possible prognostic, or any other significance. Therefore, to study the diurnal pattern of BP it may be better to include only patients with cerebral infarcts who started the 24-hour BP monitoring within 24 hours following stroke onset, and furthermore, to use as daytime values only those BP values measured between $9.00 \mathrm{~h}$ and $18.00 \mathrm{~h}$ and as nighttime values only those BP values measured between $24.00 \mathrm{~h}$ and $6.00 \mathrm{~h}$, leaving out the period in which the BP transition presumably occurs.

\section{4-hour blood pressure variation and prognosis}

There are few data on the prognostic significance of the degree of diurnal BP variation after ischemic stroke. Schrader et al. stated that nighttime hypertension resulted in worse outcome in stroke patients. ${ }^{52}$ Robinson et al. found that increased 24-hour BP levels and reduced nocturnal fall in BP were related to poor outcome, ${ }^{48}$ whereas Dawson et al. found that increased variation in diastolic and mean BP significantly related to poor outcome. ${ }^{53} \mathrm{~A}$ greater fall in mean BP level within the first days was associated with worse outcome. ${ }^{59}$ On the other hand Chamorro found that a fall of 20$30 \%$ in BP level on the second day after stroke was associated with a better outcome. ${ }^{64}$ Various studies focussed on the relationship between non-dipping and target organ damage. ${ }^{89} 98$ 101-103 ${ }^{2}$ eduction in diurnal BP variation and higher nocturnal BP values may lead to more silent brain damage and may increase the number of symptomatic infarcts. 93104105

Since few data on the prognostic significance of 24-hour BP levels after stroke are available, we studied the relationship between diurnal BP variation in the first 24 hours after stroke and outcome at six months. Furthermore, we examined whether a fall in BP between day 0 ( that is the first 24 hours) and day 4 was related to the outcome at six months. 


\section{Mechanisms of blood pressure elevation in the acute phase of stroke}

The exact cause of the BP elevation in acute stroke remains unknown. The BP elevation has been attributed to several pathophysiological mechanisms. Some authors state that the elevation is a 'white coat effect' due to hospital stress. ${ }^{46}{ }^{106-108}$ Carlberg et al. reported that casual BP levels on hospital admission had no time relationship to the stroke event during the first week, and suggested therefore that mental stress in the emergency room played a major role in the BP elevation. ${ }^{107}$ The observation that mean 24-hour BP values were lower than the first recorded admission BP value could endorse this theory..$^{59}$ Others hypothesized that injury to the central autonomic nervous system which resulted in pathologically increased sympathetic activity is a major cause of BP elevation. ${ }^{91}{ }^{109}$ Increased sympathetic activity was reflected by increased plasma catecholamine and corticosteroid levels, ${ }^{6190}{ }^{109}$ especially in nondippers, during nighttime hours. ${ }^{91}$ A diminished sensitivity of the baroreceptor arc has also been postulated. ${ }^{53} 9597$ Sander et al. provided arguments in favour of the theory that the insular cortex exerts a continous inhibiting effect on the autonomic, sympathetic nervous system; they found that patients with an infarct in especially the right-sided insular cortex had significantly higher noradrenaline levels. ${ }^{91}$ Patients with a rightsided insular infarct also exhibited diminished diurnal BP variations. ${ }^{96}$ A positive correlation between infarct size, the extent of insular damage, and plasma norepinephrine concentration was found. Britton et al. suggested that large lesions constituted a stimulus for reactive BP elevation, ${ }^{75}$ whereas Carlberg et al. did not find a relationship between lesion size and BP levels. ${ }^{107}$ Others stated that the BP elevation was a result of the Cushing reflex. ${ }^{46} 5059$ Considering the findings that BP elevation also occurs in acute lacunar stroke, ${ }^{6090}$ it is conceivable that lesion site or any cortical location does not play a major role in acute stroke BP elevation. Therefore, we hypothesized that lesion size nor site play a role, and we examined the relationship between infarct size and site and the initial level of BP and BP variation in the first 24 hours.

\section{Treatment of blood pressure in the acute phase of stroke}

The most important risk factor for a stroke event is high BP. ${ }^{252110111}$ The risk of stroke climbs with rising BP values in all age groups. Primary prevention studies show that a decrease of 5-6 mm Hg in diastolic $\mathrm{BP}^{112-115}$ and $10-12 \mathrm{mmHg}$ in systolic BP reduces the probability of stroke with about $40 \% .^{525785}$ In isolated systolic hypertension, antihypertensive therapy reduces the stroke frequency more than one third, especially in elderly people. ${ }^{528} 116117$ Considering antihypertensive treatment as secondary prevention in stroke, it is worth mentioning that a recent meta-analysis of 6752 stroke patients in 9 trials found that active treatment reduced the incidence of recurrent stroke by $28 \% .{ }^{118}$ Little is known about treatment of high BP in patients with acute stroke. ${ }^{57}$ Four small randomized controlled trials have investigated the effect of BP reduction in acute ischemic stroke, but these fail to provide evidence for a useful effect on outcome. ${ }^{4465}$ 
It is important to realize that none of these studies had as primary aim to study any effect of BP alteration in acute stroke on outcome. These were neuroprotection trials with drugs that besides potentially being neuroprotective, also appeared to have an effect on BP. Three of these randomized controlled trials studied calcium channel blockers (nimodipine or nicardipine) and found that these agents had a moderate effect on BP ${ }^{68} 119{ }^{120}$ One of these studies also found that nicardipine reduced cerebral blood flow. ${ }^{68}$ In contrast, perindopril, an angiotensin-converting-enzyme inhibitor, reduced BP without altering internal artery blood flow or middle cerebral artery blood velocity. ${ }^{114}$ No large studies of BP manipulation in acute stroke have been undertaken to date. ${ }^{65}$

In general it is recommended not to treat high BP in the acute phase of stroke because of the risk of reducing perfusion in the ischemic penumbra. ${ }^{33626768121}$ Some state that there is a theoretical advantage in delaying antihypertensive therapy after stroke in that it allows recovery of the damaged cerebral vessels, thereby restoring local autoregulation, whereas collateral circulation may also be improved. ${ }^{67}$ Others fear the theoretically detrimental effect of edema development and recommend treatment of

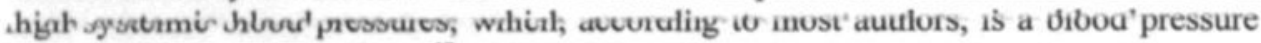
that exceeds $220 / 120 \mathrm{mmHg} .{ }^{57}$ Hachinski recommends treatment if the blood pressure is over $220 / 130 \mathrm{mmHg}$; ${ }^{122}$ Oppenheimer et al. recommend treatment if systolic BP is over $200 \mathrm{mmHg}$ or diastolic BP is over $120 \mathrm{mmHg}{ }^{123}$ and Lavin ${ }^{43}$ and Strandgaard et al. ${ }^{124}$ recommend treatment if diastolic BP exceeds $130 \mathrm{mmHg}$. The American Heart Association recommends treatment if mean arterial $\mathrm{BP}$ is higher than $130 \mathrm{mmHg}$, or if systolic BP exceeds $220 \mathrm{mmHg}$. ${ }^{125}$ When using antihypertensive therapy most authors agree not to lower the BP with more than $20 \%,{ }^{35}{ }^{56}$ with reduction of diastolic BP values to $100-110 \mathrm{mmHg}^{41}{ }^{434552}$ Antihypertensive treatment is recommended in the rare cases of malignant hypertension and hypertensive encephalopathy, or when vital organs as heart or kidney are compromized by the elevated BP.

In general, antihypertensive treatment should not be considered during the period in which BP declines spontaneously, i.e. in the first 10 days following stroke onset. ${ }^{126}$ Antihypertensive treatment should await the spontaneous decline in BP and only be initiated if BP remains elevated beyond the first 10 days after stroke. In patients already on antihypertensive treatment prior to stroke it may be prudent, if the used medication allows it, to withhold or reduce this antihypertensive medication for 7 to 10 days, but this issue is also still unsettled. ${ }^{57}$ The differences between these recommendations reflect the absence of any evidence on how and when to treat BP in acute stroke. Ideally, large clinical trials should settle the issue, whether BP manipulation is of value to preserve ischemic tissue and improve prognosis in acute stroke. However, BP level varies largely in acute stroke patients, ${ }^{41}$ and prognosis is likely the result of various factors. Therefore, more knowledge on factors that influence early BP characteristics in acute stroke, and on how BP variables independently predict stroke outcome is required, before any therapeutical experiment on BP manipulation in stroke patients can rationally be performed. The studies described in this thesis aim to provide such information. 
The contents of the various chapters are as follows:

Chapter 1: introduction on various aspects of $\mathrm{BP}$ in acute stroke.

Chapter 2: BP course and predictors of BP level following acute stroke; a retrospective evaluation.

Chapter 3: prognostic value of various BP variables in acute stroke; a retrospective exploration.

Chapter 4: prognostic value of the first BP measured after admission in acute stroke patients; a prospective exploration.

Chapter 5: prospective 24-hour BP monitoring after acute stroke: degree of diurnal BP variation and relationship of various factors with BP variation.

Chapter 6: prognostic value of various BP variables obtained prospectively by 24-hour BP monitoring after acute stroke.

Chapter 7: influence of ischemic lesion site and size on BP level in acute stroke.

Chapter 8: general discussion. 
2

Predictors of post-stroke blood pressure level and course

Accepted for publication in Journal of Stroke and Cerebrovascular Diseases.

Authors: Boreas AMHP, Lodder J, Kessels F, de Leeuw PW, Troost J. 


\section{Abstract}

\section{Background}

Blood pressure (BP) is often elevated in acute stroke. Predictors of BP level, and BP course during the first week following stroke remain unclear. Furthermore, most studies on BP course did not consider separate stroke subtypes. Knowledge of such factors may be of relevance when manipulation of early BP levels are considered as potentially therapeutic in acute stroke.

\section{Methods}

Blood pressures were collected by reviewing BP records of 817 patients with a first-ever infarct who were admitted to a stroke unit, between 1987 and 1992 . We only selected those patients who were admitted within 24 hours following stroke onset. We studied the first systolic and diastolic BP measured after admission to the stroke unit. Furthermore, we studied the mean daytime and nighttime systolic and diastolic BP, taken during the first seven days following stroke onset.

\section{Results}

Age and known hypertension before stroke were significantly associated with elevated post-stroke BP level, whereas ischemic heart disease was associated with a lower BP level. BP decline in the post-stroke period related to the degree of initial BP elevation. BP in hypertensive patients remained higher than in non-hypertensive patients during the first post-stroke week. We found no difference in initial BP level, nor the rate of BP decline from day 0 to 4 between patients with a lacunar infarct and those with an infarct involving the cortex.

\section{Conclusion}

Our findings indicate that BP increase post-stroke is not a general phenomenon, nor is BP decline in the first post-stroke week, whereas it does not depend on stroke subtype. Known hypertension is probably the strongest predictor of post-stroke BP increase. 


\section{Introduction}

Blood pressure (BP) is often elevated in acute stroke, but falls spontaneously during the following days. ${ }^{424858862}$ It is unclear whether this phenomenon represents a physiological response to maintain or enhance perfusion in reversibly damaged cerebral tissue, or is merely a marker of stroke severity. ${ }^{4247464}$ However, increased early BP is not related to the type of event, as its incidence is similar in patients with cerebral hemorrhage, infarction, and TIA. ${ }^{63} 75$ However, most studies on BP course in early stroke did not consider separate stroke subtypes, or included patients at an undefined moment varying from 24 hours to 7 days after stroke onset. ${ }^{54} 6375107$ Furthermore, circadian BP changes were rarely taken into account. ${ }^{546375107}$ So, factors that predict BP level following stroke, BP course and circadian influence on this course remain unclear. Knowledge of such factors may be of relevance when manipulation of early BP abnormalities is considered as a potentially therapeutic option in acute stroke. Therefore, in patients who were admitted with a first cerebral infarct and who had their first BP recordings within 24 hours following stroke onset, we analysed the impact of various aspects of BP in the first week. We also explored which variables determine the level of BP in the acute phase of stroke and early BP decline.

\section{Patients and Methods}

\section{Data collection}

Blood pressure values were collected by reviewing BP records of patients registered in an ongoing stroke registry at the University Hospital of Maastricht. The University Hospital is the only hospital in the region of Maastricht and has an adherent population of approximately 190,000 people. The stroke registry contains prospective data of patients who had been admitted to the neurological department or had visited the outpatient's clinic, with a first-ever cerebral infarct with symptoms lasting longer than 24 hours. Routine investigations included standard blood tests, electrocardiogram, chest X-ray, CT scan of the brain and noninvasive carotid artery studies. Echocardiography, 24-hour ECG monitoring and cerebral angiography were done in selected cases.

In this study, 430 patients with a first-ever infarct had been admitted within 24 hours following stroke onset. Patients admitted to hospital stayed on the stroke unit until they were neurologically stable, after which they were transferred to the general neurological ward. Blood pressure was recorded manually by experienced nursing staff with a mercury sphygmomanometer (blood pressure values at 1st and 5th Korotkoff sounds taken as systolic and diastolic, respectively). Measurement frequency depended on the individual patient's condition and no fixed schedule had been enforced. Therefore, the frequency of BP measurements per patient and per day varied. For analysis we used those BP-values that were measured within the first 24 hours after the patient was admitted to hospital and the next seven days after admittance. To adjust for the different number of $\mathrm{BP}$ recordings per patient per day, we took the average of three BP-values obtained be- 
tween $9.00 \mathrm{~h}$ and $18.00 \mathrm{~h}$ (recordings closest to $10.00 \mathrm{~h}, 15.00 \mathrm{~h}$ and $18.00 \mathrm{~h}$ ) as daytime $\mathrm{BP}$ values, and the average of three BP-values taken between $24.00 \mathrm{~h}$ and $6.00 \mathrm{~h}$ (closest to $24.00 \mathrm{~h}, 03.00 \mathrm{~h}$ and $06.00 \mathrm{~h}$ ) as nighttime BP values. BP values registered between $6.00 \mathrm{~h}$ and $9.00 \mathrm{~h}$ and between $18.00 \mathrm{~h}$ and $24.00 \mathrm{~h}$ were not included in the analyses, because in these periods the BP-switch between the nocturnal and diurnal period is assumed to occur. ${ }^{82}$

To evaluate the course of the BP during the first week after admittance, we also used BPvalues of a control-group for comparison. This control-group consisted of 134 patients known with hypertension, who had been admitted to the internal ward of our hospital to analyse their hypertension. These patients received no antihypertensive medication during hospital stay. Their BP was recorded every 2 hours between $07.00 \mathrm{~h}$ and $23.00 \mathrm{~h}$ by an automatic device. The average of the systolic and diastolic BP values was registered per day, from day 0 to day 7 after admission to hospital.

\section{Blood pressure variables}

For the stroke group, we used the following variables:

- first systolic BP and first diastolic BP measured after admission to the stroke unit.

- daytime systolic BP (DSBP) and diastolic BP (DDBP), as defined above.

- nighttime systolic BP and diastolic BP, as defined above.

\section{Definitions}

Hypertension (HT) was defined as known hypertension (blood pressure recordings of more than $160 \mathrm{mmHg}$ systolic and/or $90 \mathrm{mmHg}$ diastolic pressure on at least two different occasions) whether or not treated with antihypertensive medication before the stroke. Diabetes mellitus (DM) was defined as known diabetes treated with diet or medication, or either a fasting blood glucose higher than $7 \mathrm{mmol} / 1$ or a postprandial blood glucose higher than $11 \mathrm{mmol} / \mathrm{l}$ measured on at least two separate occasions before or at least one week after the stroke.

Ischemic heart disease (IHD) was defined as a history of angina pectoris, myocardial infarction or coronary bypass surgery.

A brain infarct was defined as the rapid onset of clinical signs of focal cerebral function disturbance, lasting longer than 24 hours or leading to death, with no apparent cause other than that of vascular origin with normal CT or CT showing an area of low attenuation compatible with the clinical signs and symptoms, or autopsy revealing an infarct compatible with the clinical signs and symptoms. When CT scan had not been performed (21 of the 430 cases), we used the Guy's Hospital Stroke Diagnostic Score (Allen score): an Allen score less than four indicated a probability of 90 per cent or more that the stroke was due to infarction. ${ }^{129} 130$ 
A lacunar infarct $(L A C I)$ was defined as an acute stroke syndrome with a CT lesion compatible with occlusion of a single perforating artery, i.e., a small, subcortical, sharply marginated hypodense lesion with a diameter smaller than $15 \mathrm{~mm}$ (small deep infarct), or as a specific lacunar syndrome (i.e., unilateral motor and/or sensory symptoms and signs that completely involved at least 2 of 3 body parts (face, arm, and leg) without disturbance of consiousness or language, visual field defect, or other signs of cortical dysfunction) when the CT scan showed no specific lesion. A potential cardioembolic stroke cause was not taken into account when assigning patients to this infarct subgroup. A territorial infarct was defined as an acute stroke syndrome with CT findings compatible with infarction involving the cortex, or when no specific lesion was visible on CT, as a clinically identified cortical syndrome consisting of unilateral motor and/or sensory symptoms and signs in combination with signs of cortical dysfunction with or without visual field defect, or as isolated monoparesis or as isolated cortical dysfunction (usually dysphasia). Patients with a large subcortical infarct were included in the territorial infaret group because of similar pathogenesis.

Territorial infarct patients with a potential cardioembolic stroke source were assigned to the cardioembolic stroke subgroup (CE). Such patients had at least one of the following cardiac features: chronic or intermittent ECG confirmed atrial fibrillation; left ventricular myocardial infarction within six weeks preceding stroke; left ventricular or atrial thrombus; left ventricular aneurysm; left ventricular akinetic segment; cardiomyopathy; mitral or aortic valve abnormalities (endocarditis, mitral stenosis, prosthetic aortic or mitral valves); and in young patients without any other specific stroke cause: atrial septal defect, ventricle septal defect. Patients with a non-cardioembolic symptomatic territorial infarct (presumably large vessel disease, i.e. atherothrombosis or artery-to-artery embolism whether or not confirmed by non-invasive carotid studies) were assigned to the atherothrombotic infarct subgroup $(A T)$. There were 21 patients with a 'rare' stroke cause, such as arterial dissection, vasculitis, fibromuscular dysplasia, hematological disorder, etc. Because of small numbers and heterogeneity in stroke cause, this group was not included in this study, leaving 409 patients for analysis.

The modified Rankin scale was used to describe the degree of functional handicap on admission (see appendix). ${ }^{131}$

\section{Statistical analysis}

To study the correlation between the different variables and BP we used a linear regression model containing the following independent variables: stroke type (LACI vs $\mathrm{CE}$ and vs AT), Rankin score on day 0 ( score $3-5$ vs 1,2 ) as a measure of stroke severity, age ( $<60$ vs $60-75$ and vs $>75$ years ), IHD, sex, DM, and hypertension before stroke (HT). As dependent variable we used the different BP variables. We used the one-way Anova-test to study the difference between initial BP values in the various stroke subtypes and to assess the difference between the course of BP during the first week in these stroke subtypes. 


\section{Results}

\section{Patients and BP measurements}

We used data of 409 consecutive registered patients who had been admitted within 24 hours (day 0) following stroke onset. In 403 patients at least one BP value was taken on day 0 . Of these 403 patients, 291 had BP measurements during daytime, whereas 284 had BP measurements during the night. The number of patients with at least one BP measurement per day during the daytime was 291 on day 0 declining to 112 on day 7 , whereas the number of patients with at least one BP measurement per day during the nighttime was 284 on day 0 declining to only 8 at day 7 .

Only 57 patients had consecutive daily BP measurements from day 0 upto and including day 7 , whereas only 7 patients had these consecutive measurements during nighttime hours. As mentioned earlier, BP measurement frequency per patient per day varied: the median number of BP values measured was 4 (range 1-19) on day 0,7 (range 1-24) on day one, 4 (range 1-23) on day two, 3 (range 1-24) on day three, 2 (range 1-22) on day four, 2 (range 1-15) on day five, 2 (range 1-20) on day six and 2 (range 1-20) on day seven. Of the 403 patients, 34 died during the first week following stroke onset.

\section{Patient characteristics and level of first BP readings}

Table 1 shows patient characteristics for all 403 patients and for the various stroke subgroups.

Table 1: Patient characteristics for stroke subgroups (for abbreviations see text)

\begin{tabular}{lllll}
\hline & $\begin{array}{l}\text { Total group } \\
\mathrm{N}=403) \\
\mathrm{N},(\%)\end{array}$ & $\begin{array}{l}\text { LACI } \\
(\mathrm{N}=106) \\
\mathrm{N},(\%)\end{array}$ & $\begin{array}{l}\mathrm{CE} \\
\mathrm{N}=126) \\
\mathrm{N},(\%)\end{array}$ & $\begin{array}{l}\mathrm{AT} \\
\mathrm{N}=171) \\
\mathrm{N},(\%)\end{array}$ \\
\hline Sex: male & $196(51)$ & $54(51)$ & $46(37)$ & $96(56)$ \\
$\quad$ female & $207(49)$ & $52(49)$ & $80(63)$ & $75(44)$ \\
Age: median (range) & $73(24-96)$ & $69(39-95)$ & $77(24-96)$ & $73(39-92)$ \\
IHD & $118(29)$ & $29(27)$ & $48(38)$ & $41(24)$ \\
DM & $74(18)$ & $15(14)$ & $30(24)$ & $29(17)$ \\
HT & $189(47)$ & $52(49)$ & $61(48)$ & $76(45)$ \\
Rankin at stroke & $161(40)$ & $71(67)$ & $35(28)$ & $55(32)$ \\
$\quad$ onset: $\leq 3$ & $242(60)$ & $35(33)$ & $91(72)$ & $116(68)$ \\
\hline
\end{tabular}


Linear regression analysis showed that the level of first BP measured after admission was significantly associated with $\mathrm{IHD}$, age and hypertension $(\mathrm{N}=403)$ : in patients known with IHD before stroke, the first systolic and diastolic BP values were 12 and $5 \mathrm{mmHg}$, respectively, lower than in those without IHD. In patients known with hypertension before stroke, the first systolic and diastolic BP values were 16 and $8 \mathrm{mmHg}$, respectively, higher than in those without. With every year of life, systolic BP increased by $0.4 \mathrm{mmHg}$. The remaining variables, including stroke subtype and Rankin score on day 0 , were not significantly associated with the first BP value (table 2).

Table 2: Association between several independent variables and level of first systolic and diastolic BP and the fall in daytime systolic BP (DSBP). Data are linear regression coefficient for the associations.

\begin{tabular}{|c|c|c|c|c|c|c|}
\hline Dependent variables & $\begin{array}{l}\text { Coefficient } \\
\text { systolic } \\
\text { BP }\end{array}$ & $\begin{array}{l}\text { P-value } \\
\text { systolic } \\
\text { BP }\end{array}$ & $\begin{array}{l}\text { Coefficient } \\
\text { diastolic } \\
\text { BP }\end{array}$ & $\begin{array}{l}\text { P-value } \\
\text { diastolic } \\
\text { BP }\end{array}$ & $\begin{array}{l}\text { Coefficient } \\
\text { fall } \\
\text { DSBP }\end{array}$ & $\begin{array}{l}\text { P-value } \\
\text { fall } \\
\text { DSBP }\end{array}$ \\
\hline Stroketype: Ce vs Laci & -6 & ns & -1 & ns & -4 & ns \\
\hline At vs Laci & -2 & ns & -3 & ns & -4 & ns \\
\hline IHD & -12 & $<0.0001$ & -5 & 0.002 & 1 & ns \\
\hline DM & 6 & ns & -0.06 & ns & 6 & ns \\
\hline Age & 0.4 & 0.007 & -0.04 & ns & 0.1 & ns \\
\hline Sex & -5 & ns & -2 & ns & 0.01 & ns \\
\hline HT & 16 & $<0.0001$ & 8 & $<0.0001$ & 8 & 0.04 \\
\hline \multicolumn{7}{|l|}{ Rankin at stroke onset } \\
\hline 3 vs 1,2 & -0.3 & ns & -1 & ns & 2 & ns \\
\hline 4 vs 1,2 & 3 & ns & -1 & ns & 4 & ns \\
\hline 5 vs 1,2 & -3 & ns & -3 & ns & 10 & ns \\
\hline
\end{tabular}

Relationship between patient characteristics and BP decline during the first few days

The extent to which nighttime systolic and diastolic BP fell between day 0 and day 4 was not significantly associated with any of the patient characteristics. The decline in daytime diastolic BP was also not significantly associated with these variables. The decline in daytime systolic BP between day 0 and day 4 showed only a significant association with priorly established hypertension: in patients with hypertension, the BP fall between day 0 and 4 was $8 \mathrm{mmHg}$ greater than in patients without (table 2).

Time course of blood pressure in the first week following stroke onset

Figures 1 and 2 illustrate the time course of daytime systolic and diastolic BP in the first week after stroke onset for stroke patients and after admittance to hospital for controls. For stroke patients the greatest decline in BP was observed during the first 3 days. The nighttime systolic and diastolic BP showed a similar course (not shown). 
The control group also showed a decline in BP during the first week, with a similar magnitude as in the stroke group.

Fig. I: course daytime systolic (DSBP) blood pressure
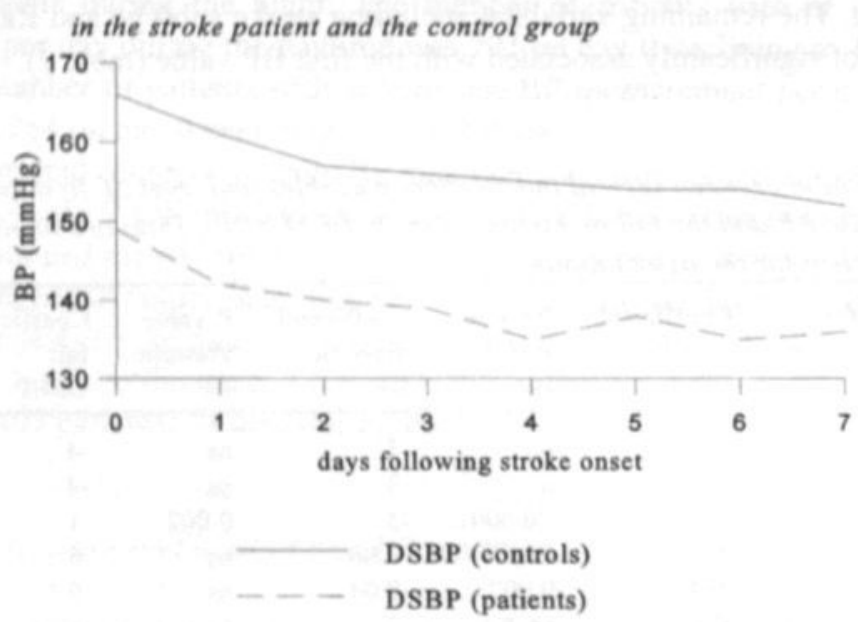

Fig. 2: course daytime diastolic (DDBP) blood pressure
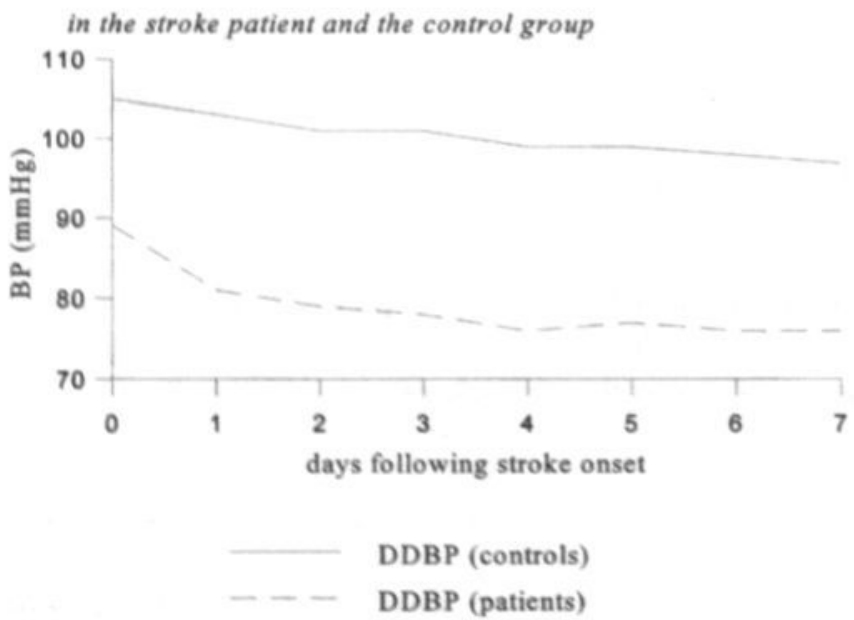
Figure 3 illustrates the daytime systolic and diastolic BP course of stroke patients with and without hypertension. 144 of the 291 patients with daytime BP registrations had hypertension before stroke; $76 \%(\mathrm{~N}=109)$ of them used antihypertensive medication on admission. This antihypertensive medication was stopped in 17 patients on day 1 .

147 of the 291 patients with daytime BP registrations were without hypertension before stroke; $32 \%(\mathrm{~N}=47)$ of these used blood pressure lowering medication at admission, mainly for cardiac failure. In 4 patients this medication was stopped at day 1. BP during the first week was higher in patients with hypertension than in those without hypertension. This difference in BP level was also evident when the nighttime systolic and diastolic BP values were analysed separately.
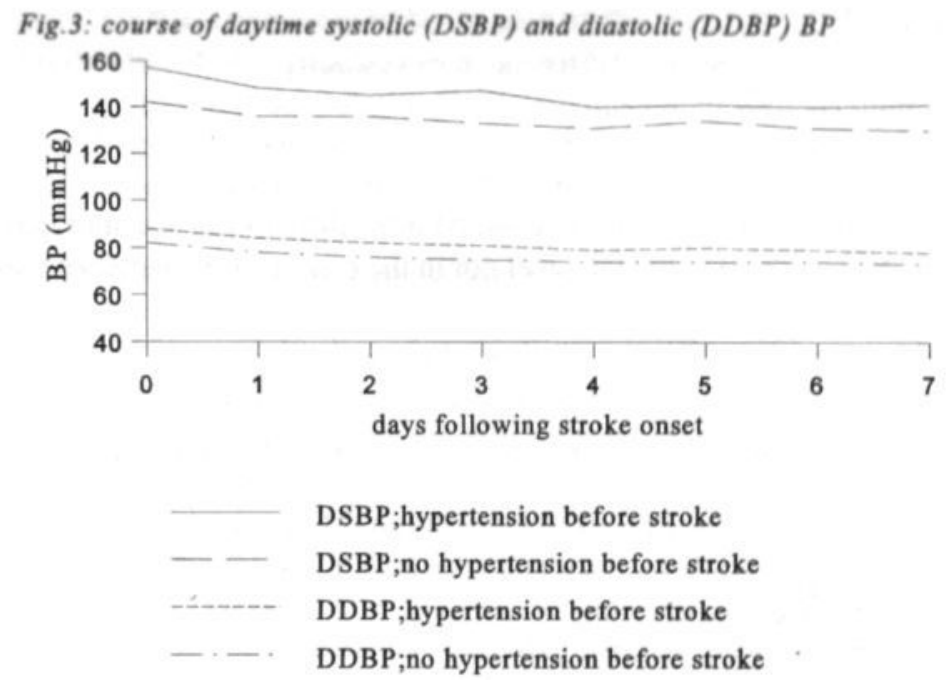

Figure 4 shows the time course of daytime systolic BP, when patients were divided into three equal parts ('tertiles') on the basis of their BP on day $0.65 \%$ of the patients in the upper tertile group were known with hypertension at stroke onset, $56 \%$ of them used antihypertensive medication at day $0 . \mathrm{BP}$ in this upper tertile group showed the greatest decline, but BP at the end of the week was still higher than in the other two groups. Daytime diastolic, nighttime systolic and diastolic BP values on day 0 divided in tertiles, showed a similar pattern. 
Fig.4: course daytime systolic blood pressure (DSBP)

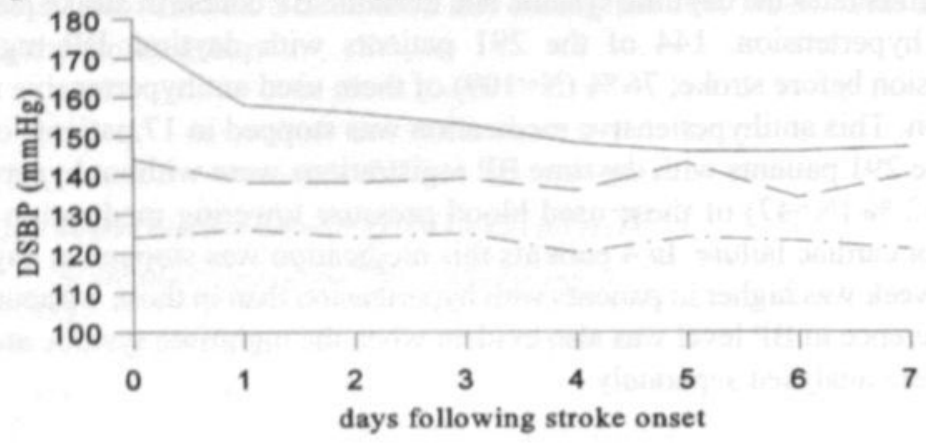

DSBP day $0>149 \mathrm{mmHg}$

DSBP day $0>130$ and $<150 \mathrm{mmHg}$

DSBP day $0<131 \mathrm{mmHg}$

Figure 5 shows the daytime systolic BP course for the different stroke subtypes. There was no significant difference in initial BP level nor in the course of BP between these different stroke subgroups.

Fig.5: course daytime systolic BP for the stroke subtypes

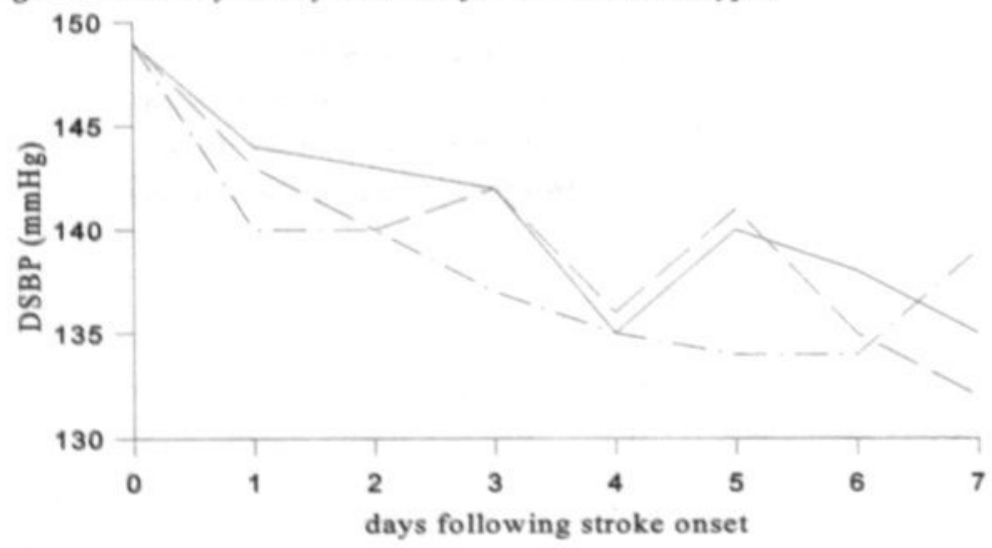

Laci $--\mathrm{Ce}-\cdots-\mathrm{At}$

\begin{tabular}{|c|c|c|c|c|c|c|c|}
\hline Laci $(\mathrm{N})$ & 74 & 53 & 51 & 43 & 40 & 39 & 39 \\
\hline $\mathrm{Ce}(\mathrm{N})$ & 89 & 74 & 68 & 62 & 60 & 55 & 54 \\
\hline At (N) & 128 & 108 & 90 & 62 & 79 & 78 & 70 \\
\hline
\end{tabular}




\section{Discussion}

Blood pressure (BP) is often elevated following hospital admission because of a stroke, but falls spontaneously during the following days. ${ }^{4285} 586267$ Such a decline in BP, however, also occurs in patients without a stroke. Some data suggest that high post-stroke BP is associated with unfavourable outcome. ${ }^{42} 467475$ If this is true, than modifiable factors which determine post-stroke BP elevation, may potentially be therapeutically useful. We explored such factors and found age and known hypertension to be predictors of an elevated post-stroke BP level, whereas ischemic heart disease was a determinant of a lower BP. BP lowering drugs given for ischemic heart disease may explain the latter finding, as one third of our patients used such drugs. Surprisingly, early post-stroke BP was elevated in patients with known hypertension, even though about three quarters of them used BP lowering drugs. In addition, BP remained higher than in non-hypertensive patients during the first post-stroke week. Post-stroke BP elevation may be caused by an increase in adrenal hormones, but this is unlikely to be the sole mechanism. ${ }^{47619096}{ }^{109}$ Impaired baroreceptor sensitivity after stroke could also play a role. ${ }^{95}{ }^{132}$ Hypertensive patients are also more sensitive to sympathetic stimulation, ${ }^{4491} 97$ and this could well account for BP elevation following stroke in such patients. Such elevation occurred despite antihypertensive drug treatment in our study. Our data further show that the BP decline in the post-stroke period is related to the initial BP elevation. Therefore, if an elevated post-stroke BP is to affect outcome unfavourably, in a therapeutic experiment only elevated BP should be lowered.

Some suggest that site and size of the lesion may be related to BP elevation following stroke. ${ }^{43636975}$ However, we found no difference in initial BP level, nor the magnitude of BP decline, between patients with lacunar infarcts and those with infarcts involving the cortex, regardless of whether the latter were caused by cardiac embolism or by large artery tromboembolism. This argues against an important role of certain cortical areas or the degree of cerebral tissue damage in causing post-stroke BP elevation. ${ }^{9192} 109$

An obvious limitation of our study is its retrospective character. Thus, the frequency with which BP measurements were obtained may have been dictated by the number of priorly measured abnormal BP values. This may have caused bias towards more frequent detection of higher BP values. Therefore, prospective BP measurements, using a rigid protocol, in a large stroke series are required to verify our data. For the time being, however, we may conclude that an increase in post-stroke BP is not a general phenomenon, nor is the decline in BP in the first week post-stroke. Known hypertension is probably the strongest predictor of a post-stroke BP increase. 
3

\section{Prognostic value of blood pressure in acute stroke}

Submitted.

Authors: Boreas AMHP, Lodder J, Kessels F, de Leeuw PW, Troost J. 


\section{Abstract}

\section{Background}

Manipulation of blood pressure (BP) in acute stroke may improve outcome. Despite various studies, data on the prognostic significance of early BP in stroke remain unclear. Therefore, we studied the relationship between various BP variables in the acute phase of stroke and functional outcome at three months.

\section{Methods}

$\mathrm{BP}$ values were collected by reviewing $\mathrm{BP}$ records of 817 patients who were admitted to our stroke unit. Besides the first systolic and diastolic admission BP (SBP and DBP), we also used the mean of the daytime as well as the mean of the nighttime systolic and diastolic BP values. Finally, we studied the relationship between the decrease in BP between day 0 and 4 and outcome. As dependent outcome variable we used the Rankin handicap score at three months dichotomized in a score $>3$ (poor outcome) versus a score $\leq 3$ (good outcome).

\section{Results}

409 patients were admitted within 24 hours following stroke onset. Only nighttime systolic BP $\geq 165 \mathrm{mmHg}$ (OR 2.8; 95\% CI 1.1-6.8), nighttime diastolic BP $\leq 60 \mathrm{mmHg}$ (OR 8.1; 95\% CI 1.1-58.3), and a decrease in daytime diastolic BP between day 0 and 4 of $210 \mathrm{mmHg}$ (OR 3.0; 95\% CI 1.1-7.9) showed a significant relationship with poor outcome. The rest of the BP variables did not show a significant relationship with functional outcome at three months.

\section{Conclusions}

Our findings suggest that admission BP values may not reliably reflect any impact of BP on stroke outcome. They also suggest a potential differential effect of BP manipulation: increasing or decreasing BP may be beneficial for patients with BP extremes in one direction, but detrimental for those with $\mathrm{BP}$ values in the opposite direction. 


\section{Introduction}

A transient increase in arterial blood pressure (BP) frequently occurs in patients with acute stroke. ${ }^{44} 48$ This could be a physiological response to maintain or enhance perfusion of reversibly damaged cerebral tissue, when normal autoregulatory mechanisms are impaired. ${ }^{67}$ However, the general benefit of such a response could be questioned, as high BP in the early phase has been linked to poor outcome, particularly in patients with impaired consciousness. ${ }^{4655}$ In a recent overview Bath reported that some studies failed to establish a relationship between admission BP and outcome, ${ }^{70} 7$ although low systolic pressure may be associated with poor outcome. ${ }^{4465}$ Most series so far included only single admission BP readings to study outcome. ${ }^{46} 7477133$ Moreover, BP was not always studied as an independent predictor. ${ }^{n}$ A single admission BP value may not reflect the extent to which BP changes over time may influence outcome, especially since the ischemic penumbra may be present for a prolonged period of time. Furthermore, variations in BP occur as a result of diurnal rhythm. Earlier studies reported that patients with a blunted fall in nighttime BP are more likely to suffer hypertensive target-organ damage, which would mean that BP during sleep is more closely related to target-organ damage than BP in the awake state. ${ }^{85} 86899299$ Therefore, in the present study, we analysed various BP characteristics (including daytime and nighttime BP values) as independent predictors of outcome at three months in patients admitted to a stroke unit within 24 hours following stroke onset. We also explored whether a drop in BP values during the first four days was related to outcome.

\section{Patients and Methods}

\section{Data collection}

Blood pressure values were collected by reviewing BP records of patients registered in an ongoing stroke registry at the University Hospital of Maastricht. The University Hospital is the only hospital in the region of Maastricht and has an adherent population of approximately 190,000 people. The stroke registry contains data of patients who had been admitted to the neurological department or had visited the outpatient's clinic, with a first-ever clinical cerebral infarct with symptoms lasting longer than 24 hours. Routine investigations included standard blood tests, electrocardiogram, chest X-ray, CT scan of the brain and noninvasive carotid artery studies. Echocardiography, 24-hour ECG monitoring and cerebral angiography were done in selected cases.

In this study, 430 patients with a first-ever infarct had been admitted within 24 hours following stroke onset. Patients admitted to hospital stayed on the stroke unit until they were neurologically stable, after which they were transferred to the general neurological ward. Blood pressure was recorded manually by experienced nursing staff with a mercury sphygmomanometer (blood pressure values at 1 st and 5 th Korotkoff sounds taken as systolic and diastolic, respectively). Measurement frequency depended on the individual patient's condition and no fixed schedule had been enforced. Therefore, 
the frequency of BP measurements per patient and per day varied. For this study we only used those BP values that were obtained during the first 24 hours after admission. To adjust for the different number of $\mathrm{BP}$ recordings per patient per day, we took the average of three BP-values recorded between $9.00 \mathrm{~h}$ and $18.00 \mathrm{~h}$ (recordings closest to $10.00 \mathrm{~h}$, $15.00 \mathrm{~h}$, and $18.00 \mathrm{~h}$ ) as daytime BP values, and the average of three BP-values taken between $24.00 \mathrm{~h}$ and $6.00 \mathrm{~h}$ (closest to $24.00 \mathrm{~h}, 3.00 \mathrm{~h}$ and $6.00 \mathrm{~h}$ ) as nighttime BP values. $B P$ values registered between $6.00 \mathrm{~h}$ and $9.00 \mathrm{~h}$ and between $18.00 \mathrm{~h}$ and $24.00 \mathrm{~h}$ were not included in the analyses, because in these periods it is assumed that the BP-switch between the nighttime and daytime period occurs. ${ }^{82}$ We also analysed the first blood pressure taken after admission to the stroke unit.

\section{Outcome measures}

All patients were studied as part of a long term follow-up study of stroke. For the present study the score on the Rankin handicap-scale at three months was used as outcome variable (see appendix). ${ }^{131}$ The score was dichotomized into a score $>3$ (poor outcome) versus a score $\leq 3$ (good outcome). ${ }^{134} 135$

\section{Blood pressure variables}

We explored the following variables:

- first systolic BP (first SBP) and first diastolic BP (first DBP) measured after admission to the stroke unit.

- daytime systolic BP (daytime SBP) and diastolic BP (daytime DBP), as defined above.

- nighttime systolic BP (nighttime SBP) and diastolic BP (nighttime DBP), as defined above.

\section{Definitions}

Hypertension (HT) was defined as known hypertension (blood pressure recordings of more than $160 \mathrm{mmHg}$ systolic and/or $90 \mathrm{mmHg}$ diastolic pressure on at least two different occasions) whether or not treated with antihypertensive medication before the stroke.

Diabetes mellitus $(D M)$ was defined as known diabetes treated with diet or medication, or either a fasting blood glucose higher than $7 \mathrm{mmol} / \mathrm{l}$ or a postprandial blood glucose higher than $11 \mathrm{mmol} / \mathrm{m}$ measured on at least two separate occasions before or at least one week after the stroke.

Ischemic heart disease (IHD) was defined as a history of angina pectoris, myocardial infarction or coronary bypass surgery.

A brain infarct was defined as the rapid onset of clinical signs of focal cerebral function disturbance, lasting longer than 24 hours or leading to death, with no apparent cause other 
than that of vascular origin with normal CT or CT showing an area of low attenuation compatible with the clinical signs and symptoms, or autopsy revealing an infaret compatible with the clinical signs and symptoms. When CT scan had not been performed (21 of the 430 cases), we used the Guy's Hospital Stroke Diagnostic Score (Allen score): an Allen score less than four indicated a probability of 90 per cent or more that the stroke was due to infarction. 129130

A lacunar infarct $(\mathrm{LACI})$ was defined as an acute stroke syndrome with a CT lesion compatible with occlusion of a single perforating artery, i.e., a small, subcortical, sharply marginated hypodense lesion with a diameter smaller than $15 \mathrm{~mm}$ (small deep infarct), or as a specific lacunar syndrome (i.e., unilateral motor and/or sensory symptoms and signs that completely involved at least 2 of 3 body parts (face, arm, and leg) without disturbance of consiousness or language, visual field defect, or other signs of cortical dysfunction) when the CT scan showed no specific lesion. A potential cardioembolic stroke cause was not taken into account when assigning patients to this infarct subgroup. A territorial infarct was defined as an acute stroke syndrome with CT findings compatible with infarction invoiving the cortex, or when no specinc iesion was visibie on C 1, as a clinically identified cortical syndrome consisting of unilateral motor and/or sensory symptoms and signs in combination with signs of cortical dysfunction with or without visual field defect, or as isolated monoparesis or as isolated cortical dysfunction (usually dysphasia). Patients with a large subcortical infarct were included in the territorial infarct group because of similar pathogenesis.

Territorial infarct patients with a potential cardioembolic stroke source were assigned to the cardioembolic stroke subgroup (CE). Such patients had at least one of the following cardiac features: chronic or intermittent ECG confirmed atrial fibrillation; left ventricular myocardial infarction within six weeks preceding stroke; left ventricular or atrial thrombus; left ventricular aneurysm; left ventricular akinetic segment; cardiomyopathy; mitral or aortic valve abnormalities (endocarditis, mitral stenosis, prosthetic aortic or mitral valves); and in young patients without any other specific stroke cause: atrial septal defect, ventricle septal defect. Patients with a non-cardioembolic symptomatic territorial infarct (presumably large vessel disease, i.e. atherothrombosis or artery-to-artery embolism whether or not confirmed by non-invasive carotid studies) were assigned to the atherothrombotic infarct subgroup (AT). There were 21 patients with a 'rare' stroke cause, such as arterial dissection, vasculitis, fibromuscular dysplasia, hematological disorder, etc. Because of small numbers and heterogeneity in stroke cause, this group was not included in this study, leaving 409 patients for analysis.

\section{Statistical analysis}

For analysis we used a logistic regression model containing the following independent variables: stroke type (LACI vs CE and vs AT), Rankin score on day 0 (score 3-5 vs $1,2)$ as a measure of stroke severity scale, age ( $<60$ vs $60-75$ and vs $>75$ years ), IHD, sex, $\mathrm{DM}$, hypertension before stroke (HT) and the various BP variables. As dependent 
outcome variable we used the Rankin handicap score at three months, dichotomized in a score $>3$ vs a score $\leq 3$.

To determine the cut-off points for the different BP values we used the following method:

1. The Rankin score at three months was dichotomized into a score $>3$ vs $\leq 3$.

2. The patients were sorted in ascending order by their blood pressure.

3. For patients with the same BP, the mean of the dichotomized Rankin score was calculated; this new mean Rankin value was subsequently assigned to all patients with this same BP.

4. The moving averages of the new mean Rankin scores were calculated, using a group size of 101 patients. ${ }^{136}$

5. As the calculated average could be interpreted as an estimate of the probability of an outcome with a Rankin score $>3$, the Odds of this average was calculated by dividing the average by one minus the average.

6. The logOdds was plotted against the value of the blood pressure of the 51th patient of the concerning average.

Based upon these plots, the BP data were divided into three parts: the cut-off points were established at $10 \mathrm{mmHg}$ below and $10 \mathrm{mmHg}$ above the BP-value that went together with the lowest logOdds. The BP data were put into the multivariate logistic regression model. By changing the cut-off points by adding or subtracting $5 \mathrm{mmHg}$, we tried to determine which cut-off points showed the most significant relationship with outcome.

\section{Results}

409 patients were admitted within 24 hours following stroke onset (designated as day 0 ). 403 patients had BP values registered during these first 24 hours. Only 291 patients had BP measurements during the daytime, whereas 284 had BP measurements during the nighttime on day 0 . Table 1 shows the distribution of the independent variables between the different stroke subtype groups.

Table 1: Patient characteristics in stroke subgroups (for abbreviations see text)

\begin{tabular}{|c|c|c|c|c|}
\hline & $\begin{array}{l}\text { Total group }(\mathrm{N}=403) \\
\mathrm{N},(\%)\end{array}$ & $\begin{array}{l}\mathrm{LACl}(\mathrm{N}=106) \\
\mathrm{N},(\%)\end{array}$ & $\begin{array}{l}\mathrm{CE}(\mathrm{N}=126) \\
\mathrm{N},(\%)\end{array}$ & $\begin{array}{l}\text { AT }(\mathrm{N}=171) \\
\mathrm{N},(\%)\end{array}$ \\
\hline \multirow{2}{*}{$\begin{array}{l}\text { Sex: male } \\
\text { female }\end{array}$} & $196(51)$ & $54(51)$ & $46(37)$ & $96(56)$ \\
\hline & 207 (49) & $52(49)$ & $80(63)$ & $75(44)$ \\
\hline Age: median (range) & 73 (24-96) & $69(39-95)$ & $77(24-96)$ & $73(39-92)$ \\
\hline IHD & $118(29)$ & $29(27)$ & $48(38)$ & $41(24)$ \\
\hline DM & 74 (18) & $15(14)$ & $30(24)$ & $29(17)$ \\
\hline HT & $189(47)$ & $52(49)$ & $61(48)$ & $76(45)$ \\
\hline \multicolumn{5}{|l|}{ Rankin at stroke } \\
\hline \multirow{2}{*}{ onset: $\begin{aligned} & \leq 3 \\
& >3\end{aligned}$} & $161(40)$ & $71(67)$ & $35(28)$ & $55(32)$ \\
\hline & $242(60)$ & $35(33)$ & $91(72)$ & $116(68)$ \\
\hline
\end{tabular}


Figure 1 and 2 display the relationship between the logOdds (Rankin at three months > 3 vs $\leq 3$ ) and the different first systolic and diastolic BP values. These plots suggest that both low and high BP values are associated with poor outcome (Rankin score $>3$ ).

According to the plot, cut-off SBP values that were used for further analysis were chosen as 130 and $150 \mathrm{mmHg}$. However, when fed into the logistic regression analysis, these values did not show a significant relationship with the outcome at three months. Shifting the cut-off points by adding or subtracting $5 \mathrm{mmHg}$ did not improve the relationship with outcome (table 2). Similarly, there was no significant relationship with the outcome for DBP values (table 2). By analysing the daytime and nighttime systolic and diastolic BP values in the same way, we found that a nighttime systolic $\mathrm{BP} \geq 165$ vs $131-164 \mathrm{mmHg}$ and a nighttime diastolic $\mathrm{BP} \leq 60 \mathrm{vs} 61-109 \mathrm{mmHg}$ reached statistical significance as an independent predictor of stroke outcome with an OR of respectively 2.8 and 8.1 (table 3 ).

Fig.1: The logOdds of the moving average of the dichotomized Rankin ( $>3$ vs $\leq 3$ ) plotted against the SBP

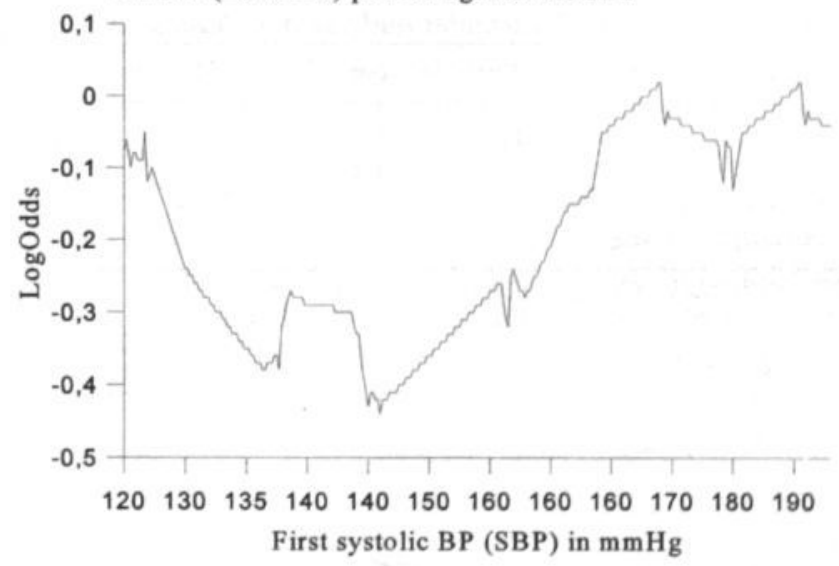


Fig.2: The logOdds of the moving average of the dichotomized Rankin ( $>3$ vs $\leq 3$ ) plotted against the DBP

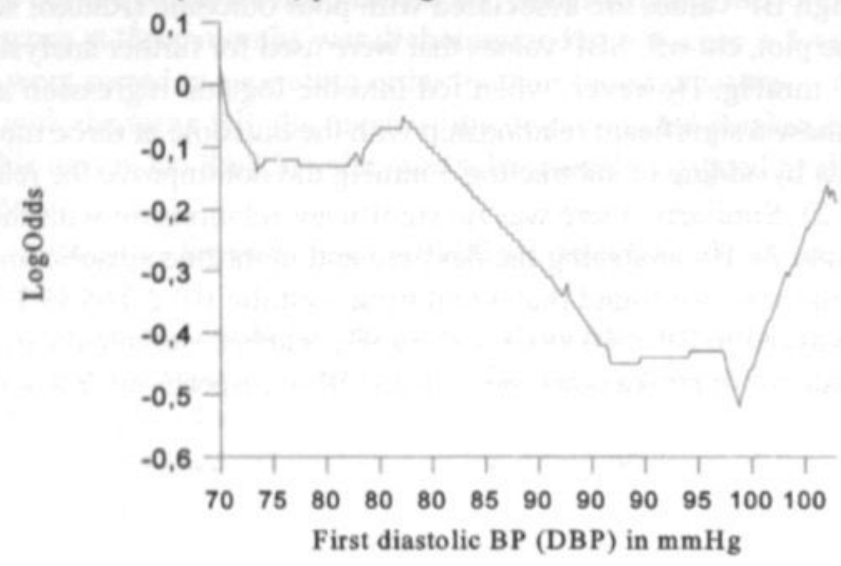

Table 2: Relationship between first BP variables and outcome:Rankin $>3$ vs $\leq 3$.

\begin{tabular}{lllll}
\hline first BP-values $(\mathrm{mmHg})$ & OR & $95 \% \mathrm{CI}$ & P-value \\
\hline \multirow{2}{*}{ first SBP } & $\leqslant 130(\mathrm{~N}=97)$ vs $131-149(\mathrm{~N}=74)$ & 1.1 & $0.4-2.8$ & $\mathrm{~ns}$ \\
& $2150(\mathrm{~N}=232)$ vs $131-149$ & 1.4 & $0.6-3.3$ & $\mathrm{~ns}$ \\
first DBP & $\leq 90(\mathrm{~N}=265)$ vs $91-109(\mathrm{~N}=92)$ & 1.1 & $0.5-2.4$ & $\mathrm{~ns}$ \\
& $\geq 110(\mathrm{~N}=46)$ vs $91-109$ & 2.1 & $0.7-6.3$ & $\mathrm{~ns}$ \\
\hline
\end{tabular}

Abbreviations: $O R=$ odds ratio, $C I=$ confidence interval

Table 3: Relationship between the daytime and nighttime BP variables and outcome: Rankin $>3$ vs $\leq 3$.

\begin{tabular}{lllll}
\hline BP- values (mmHg) & OR & $95 \% \mathrm{Cl}$ & P-value \\
\hline \multirow{2}{*}{ daytime SBP } & $\leq 145(\mathrm{~N}=157)$ vs 146-164 $(\mathrm{N}=57)$ & 0.7 & $0.3-1.9$ & ns \\
& $\geq 165(\mathrm{~N}=77)$ vs $146-164$ & 1.1 & $0.4-3.3$ & ns \\
daytime DBP & $\leq 100(\mathrm{~N}=262)$ vs $101-119(\mathrm{~N}=24)$ & 1.0 & $0.3-3.5$ & ns \\
& $\geq 120(\mathrm{~N}=5)$ vs $101-119$ & 0.1 & $0.01-2.4$ & ns \\
nighttime SBP & $\leq 130(\mathrm{~N}=85)$ vs $131-164(\mathrm{~N}=129)$ & 1.3 & $0.6-3.1$ & ns \\
& $\geq 165(\mathrm{~N}=70)$ vs $131-164$ & 2.8 & $1.1-6.8$ & 0.03 \\
nighttime DBP & $\leq 60(\mathrm{~N}=12)$ vs $61-109(\mathrm{~N}=264)$ & 8.1 & $1.1-58.3$ & 0.03 \\
& $\geq 110(\mathrm{~N}=8)$ vs $61-109$ & 1.5 & $0.2-12.7$ & $\mathrm{~ns}$ \\
\hline
\end{tabular}

Abbreviations: $O R=$ odds ratio, $C I=$ confidence interval. 
By testing the relationship between the decrease in BP values between day 0 and 4 , and stroke outcome at three months, only a decrease in daytime diastolic BP of $210 \mathrm{~mm} \mathrm{Hg}$ showed a significant relationship with outcome: OR 3.0 (table 4).

Table 4: Relationship between the decrease in BP variables and outcome: Rankin >3 vs 53.

\begin{tabular}{lllll}
\hline decrease in BP variables $(\mathrm{mmHg})$ & OR & $95 \% \mathrm{Cl}$ & P-value \\
\hline \multirow{2}{*}{ DSBP } & $\leq 0(\mathrm{~N}=53)$ vs $1-19(\mathrm{~N}=53)$ & 1.4 & $0.5-4.1$ & $\mathrm{~ns}$ \\
& $220(\mathrm{~N}=74)$ vs $1-19$ & 2.2 & $0.8-6.0$ & $\mathrm{~ns}$ \\
DDBP & $\leq-5(\mathrm{~N}=34)$ vs $-4-9(\mathrm{~N}=53)$ & 3.4 & $1.0-11.9$ & $\mathrm{~ns}$ \\
& $210(\mathrm{~N}=93)$ vs $-4-9$ & 3.0 & $1.1-7.9$ & 0.03 \\
NSBP & $\leq 5(\mathrm{~N}=28)$ vs $6-24(\mathrm{~N}=16)$ & 1.8 & $0.3-11.2$ & $\mathrm{~ns}$ \\
& $225(\mathrm{~N}=12)$ vs $6-24$ & 1.2 & $0.1-9.2$ & $\mathrm{~ns}$ \\
NDBP & $\leq 0(\mathrm{~N}=24)$ vs $1-19(\mathrm{~N}=20)$ & 3.2 & $0.5-20.6$ & $\mathrm{~ns}$ \\
& $220(\mathrm{~N}=12)$ vs $1-19$ & 0.8 & $0.1-7.3$ & $\mathrm{~ns}$ \\
\hline
\end{tabular}

Abbreviations: $O R=$ odds ratio, $C I=$ confidence interval

\section{Discussion}

Our data on the first post-stroke BP measurements suggest that high systolic and low diastolic values are associated with unfavourable outcome. Other studies also found that extreme BP values towards the lower ${ }^{5865}$ and higher ${ }^{42467475}$ end may be related with poor stroke outcome. However, after we adjusted for other prognostic variables, first measured BP levels could not be identified as independent predictors of outcome. These findings warn against unadjusted analyses of first post-stroke BP as outcome predictor.

Nighttime BP values may have a stronger predictive value for end-organ damage than daytime values. ${ }^{828586899299105137}$ A differential effect might also exist in relation to stroke outcome. Moreover, instead of analysing a single measurement such as the first one poststroke, using several BP measurements may more reliably reflect any impact of BP level on brain tissue damage or salvage. ${ }^{4898588}$ Therefore, we studied a number of daytime and nighttime BP values in separate analyses. Especially high nighttime systolic and low nighttime diastolic values were identified as independent predictors of stroke outcome.These data suggest that sustained nighttime BP values that are either extremely low or high are prognostically unfavourable.

If high BP values relate to poor outcome, it seems logical to improve prognosis by lowering blood pressure. However, our data suggest that a spontaneous BP decrease in the first five days may be independently related to poor outcome. Others also found BP decreases to be related to an unfavourable prognosis. ${ }^{6465}$ These findings warn against a too rigorous lowering of early post-stroke BP in future clinical trials.

Bias may come from our study's retrospective character: the number of $\mathrm{BP}$ measurements may relate to the measured BP level: extremely high and low values may dictate the number of the subsequent BP measurements. This could have created bias 
towards an increased chance of detecting extreme values, overestimating the strength of association between these values and outcome. Therefore, we analysed the significance of admission BP separately.

We analysed early post-stroke BP values from the perspective of a potentially salvageable penumbra during this period, as any BP-related adverse effects on the brain may be amenable by early intervention. ${ }^{42}$. 0 our data do not contradict the idea of therapeutic manipulation of post-stroke blood pressure. Indeed, lowering a very high BP may be beneficial, provided it is not lowered too drastically, while conversely increasing a low BP may confer benefit as well. ${ }^{65}$ Nevertheless, therapeutic BP manipulations should only cautiously be explored, on an individual patient basis. Furthermore, a single, first post-stroke BP measurement is probably not sufficient to rely on for such clinical trials. Multiple measurements may more reliably guide any BP manipulation, but as this takes time, it may preclude the advent of any therapeutic effect. 
4

Admission blood pressure in acute ischemic stroke: relationship with stroke subtype, and prognostic value 


\begin{abstract}
Background

Manipulation of blood pressure (BP) in acute stroke may improve outcome. Data on the prognostic significance of early BP in acute stroke remain unclear. We explored predictors of BP rise in acute ischemic stroke, and studied the level of admission BP as an independent predictor of stroke outcome.
\end{abstract}

\title{
Methods
}

BP values were collected prospectively in 271 patients admitted to our stroke unit within 24 hours following stroke onset. BP values were measured manually directly after arrival at the first aid ward. As outcome measure we used the score on the Rankin handicap scale at six months ( Rankin $>3$ as poor outcome versus Rankin $\leq 3$ as good outcome).

\section{Results}

Linear regression analysis showed that patients known with hypertension before stroke, males, and patients known with asymptomatic lacunar infarcts on CT had significantly higher first BP values, whereas patients known with ischemic heart disease had significantly lower first BP values. Univariate analysis suggested that low and high BP values were related to poor outcome, but logistic regression analysis showed no significant relationship between BP measured in acute stroke and outcome.

\section{Conclusion}

Hypertension is a strong predictor of raised $\mathrm{BP}$ in the acute phase of stroke. BP elevation is not related to stroke severity or stroke subtype. Furthermore, our data do not favour BP manipulation to serve as a potential therapy for acute stroke in general. 


\section{Introduction}

Blood pressure (BP) is elevated in 70-90\% of acute stroke patients. ${ }^{53-58}$ Elevation of admission BP has been related to stroke deterioration, mortality, or the combined endpoint 'death or severely disabled'. ${ }^{4248} 5074.76$ Others, however, did not find a relationship between admission BP level and stroke outcome. ${ }^{460-73}$ Differences between study results may relate to differences in selection of stroke subtypes, definition of end-points, method of BP measurement, and whether early BP level was studied as an independent outcome predictor. If elevated admission BP could predict prognosis, it would be rational to study whether early BP lowering would improve prognosis. The Blood Pressure in Acute Stroke Collaboration (BASC) tries to find evidence on any therapeutic effect of early BP manipulation from acute stroke trials that used vasoactive drugs. ${ }^{126}$ Both such evidence and the certainty that early elevated BP act as an independent stroke outcome predictor is required before an intervention study can be rationally planned. For various reasons, it would be desirable to restrict an intervention trial to those patients who would most likely benefit from the intervention. Considering neuroprotection in acute stroke, some have suggested to exclude patients with a lacunar infarct from trials, as it is unlikely that a significant salvageable penumbra volume exists in such patients. ${ }^{138}$ In ischemic stroke, early BP rise was related to large infarcts involving the insular cortex and even more strongly when these are located in the right hemisphere. ${ }^{91}{ }^{96}$ Therefore, patients with a lacunar infarct may differ from those with a cortical infarct with respect to early BP increase and its relevance for stroke outcome. However, lacunar stroke has rarely been studied as a separate entity in this respect.

The aim of our study was to explore predictors of BP rise in acute ischemic stroke, with special reference to lacunar stroke, and to study the level of admission BP as an independent predictor of stroke outcome.

\section{Patients and Methods}

\section{Data collection}

Between 1 January 1996 and 1 March 2000, data of patients with a stroke who were admitted to our hospital or visited the outpatient's clinic, were prospectively collected in an ongoing stroke registry at the University Hospital of Maastricht. The University Hospital is the only hospital in the Maastricht region and has an adherent population of approximately 200,000 people. Routine investigations included standard blood tests, electrocardiogram, chest X-ray, brain CT scan and carotid artery ultrasound studies. Echocardiography, 24-hour ECG monitoring and cerebral angiography were done in selected cases.

In this prospective study, 676 patients with a symptomatic ischemic stroke were admitted to our stroke unit within 24 hours following stroke onset. 516 patients of this group had a first brain infarct, whereas 160 patients had a recurrent infarct. In 271 of these 676 patients we collected 24-hour BP values prospectively. The fact that of the 676 patients 
only $271(40 \%)$ entered the study was mainly due to the availability of only two automatic monitoring devices. However, patient characteristics of the study group and of patients not included were rather similar (see table 1). Besides 24-hour BP values, we collected the first BP measured after arrival on the first aid ward: this BP was recorded manually by experienced nursing staff with a mercury sphygmomanometer (blood pressure values at 1st and 5th Korotkoff sounds taken as sytolic and diastolic, respectively). As outcome measure we used the score on the Rankin handicap-scale at six months (see appendix). ${ }^{131}$ The score was dichotomized into a score $>3$ (poor outcome) versus a score $\leq 3$ (good outcome). ${ }^{134} 135$

Table 1: Patient characteristics of patients included in the study $(N=271)$ and those who were not $(\mathrm{N}=405)$. (for abbreviations see text)

\begin{tabular}{|c|c|c|}
\hline & $\begin{array}{l}\text { Studucomun }(\mathrm{N}=271) \\
\mathrm{N},(\%)\end{array}$ & $\begin{array}{l}\text { Remainina natients }(\mathrm{N}=405) \\
\mathrm{N},(\%)\end{array}$ \\
\hline Age median (range) & 74 (35-98) & 74 (18-97) \\
\hline Gender: male & $146(54)$ & $200(49)$ \\
\hline female & $125(46)$ & $205(51)$ \\
\hline $\mathrm{HT}+$ & $141(52)$ & $182(45)$ \\
\hline $\mathrm{IHD}+$ & $91(33)$ & $125(31)$ \\
\hline Stroketype: LACI & $66(24)$ & $106(26)$ \\
\hline $\mathrm{CE}$ & $57(21)$ & $88(22)$ \\
\hline AT & $148(55)$ & $211(52)$ \\
\hline $\mathrm{DM}+$ & $47(17)$ & $72(18)$ \\
\hline \multicolumn{3}{|l|}{ CNS at admission: } \\
\hline$\leq 2$ & $25(9)$ & $37(9)$ \\
\hline$>2$ and $\leq 4$ & $34(13)$ & $62(15)$ \\
\hline$>4$ and $\leq 6$ & $46(17)$ & $56(14)$ \\
\hline$>6$ and $\leq 8$ & $87(32)$ & $110(27)$ \\
\hline$>8$ and $\leq 10$ & 79 (29) & $140(35)$ \\
\hline
\end{tabular}

Blood pressure variables

We explored the following variables:

- the first systolic (first SBP) and diastolic (first DBP) BP.

\section{Definitions}

Hypertension (HT) was defined as known hypertension (blood pressure recordings of more than $140 \mathrm{mmHg}$ systolic and/or $90 \mathrm{mmHg}$ diastolic pressure on at least two different occasions) whether or not treated with antihypertensive medication before the stroke. ${ }^{127128}$ Patients without known BP values, were considered hypertensive when treated with antihypertensive drugs. 
Diabetes mellitus (DM) was defined as known diabetes treated with diet or medication, or either a fasting blood glucose higher than $7 \mathrm{mmol} / \mathrm{l}$ or a postprandial blood glucose higher than $11 \mathrm{mmol} /$, measured on at least two separate occasions before or at least one week after the stroke.

Ischemic heart disease (IHD) was defined as a history of angina pectoris, myocardial infarction or coronary bypass surgery.

A brain infarct was defined as the rapid onset of clinical signs of focal cerebral function disturbance, lasting longer than 24 hours or leading to death, with no apparent cause other than that of vascular origin with normal CT or CT showing an area of low attenuation compatible with the clinical signs and symptoms, or autopsy revealing an infarct compatible with the clinical signs and symptoms.

A lacunar infarct (LACI) was defined as an acute stroke syndrome with a CT lesion compatible with the occlusion of a single perforating artery, i.e., a small, subcortical, sharnly marginated hypodense lesion with a diameter emaller than $15 \mathrm{~mm}$ (emall doep infarct), or as a specific lacunar syndrome (i.e., unilateral motor and/or sensory symptoms and signs that completely involved at least 2 of 3 body parts (face, arm, and leg) without disturbance of consiousness or language, visual field defect, or other signs of cortical dysfunction) when the CT scan showed no specific lesion. A potential cardioembolic stroke cause was not taken into account when assigning patients to this infarct subgroup. A territorial infarct was defined as an acute stroke syndrome with CT findings compatible with infarction involving the cortex, or when no specific lesion was visible on CT, as a clinically identified cortical syndrome consisting of unilateral motor and/or sensory symptoms and signs in combination with signs of cortical dysfunction with or without visual field defect, or as isolated monoparesis or as isolated cortical dysfunction (usually dysphasia). Patients with a large subcortical infarct or a (non-lacunar) brainstem infarct were included in the territorial infarct group because of similar pathogenesis.

Territorial infarct patients with a potential cardioembolic stroke source were assigned to the cardioembolic stroke subgroup (CE). Such patients had at least one of the following cardiac features: chronic or intermittent ECG confirmed atrial fibrillation; left ventricular myocardial infarction within six weeks preceding stroke; left ventricular or atrial thrombus; left ventricular aneurysm; left ventricular akinetic segment; cardiomyopathy; mitral or aortic valve abnormalities (endocarditis, mitral stenosis, prosthetic aortic or mitral valves); and in young patients without any other specific stroke cause: atrial septal defect, ventricle septal defect. Patients with a non-cardioembolic symptomatic territorial infarct (presumably large vessel disease, i.e. atherothrombosis or artery-to-artery embolism whether or not confirmed by non-invasive carotid studies) were assigned to the atherothrombotic infarct subgroup (AT). Patients with a 'rare' stroke cause, such as arterial dissection, vasculitis, fibromuscular dysplasia, hematological disorder, etc. were not included in the study because of small numbers and heterogeneity in stroke cause.

An infarct was considered asymptomatic if located in an area that could not account for the neurological signs and symptoms, whereas the radiologically estimated age was not consistent with the time of clinical symptoms of the index stroke (old lesions being more hypodense, more sharply delineated, or showing signs of retraction of brain structures 
towards the lesion site on CT).

Leukoaraiosis (LA) on CT was defined as focal or diffuse hypodensities in the periventricular or deep white matter, not involving the cortex, and with ill-defined margins to distinguish them from infarction. ${ }^{139}$ Stroke severity on admission was scored using the Canadian Neurological Scale (CNS) (see appendix). ${ }^{140}$

\section{Statistical analysis}

To analyse the relationship between the various BP variables and the outcome at six months we used a logistic regression model containing various combinations of the following independent variables: stroke type (as described above), CNS (as described above) or Rankin score at admission (Rankin 3, 4 or 5 vs 1 and 2), age (similar as above), IHD, gender, DM, hypertension before stroke and the various BP values as independent variables.

As dependent outcome variable we used the Rankin handicap score at six months, dichotomized in a score $>3$ vs a score $\leq 3$.

To determine the cut-off points for the different BP values we used the following method:

1. The Rankin score at six months was dichotomized as mentioned above.

2. The patients were sorted in ascending order by their blood pressure.

3. For patients with the same BP, the mean of the dichotomized Rankin score was calculated; this new mean Rankin value was subsequently assigned to all patients with this same BP.

4. The moving averages of the new mean Rankin scores were calculated, using a group size of 101 patients. ${ }^{136}$

5. As the calculated average could be interpreted as an estimate of the probability of an outcome with a Rankin score $>3$, the Odds of this average was calculated by dividing the average by one minus the average.

6. The logOdds was plotted against the value of the blood pressure of the 51st patient of the concerning average.

Based upon these plots, the BP data were divided into three parts with cut-off points at $10 \mathrm{mmHg}$ below and $10 \mathrm{mmHg}$ above the BP-value that went together with the lowest logOdds. The BP data were put into the multivariate logistic regression model. By changing the cut-off points by adding or subtracting $5 \mathrm{mmHg}$, we explored which cut-off points showed the most significant relationship with outcome.

\section{Results}

Of the 271 patients, 209 had a first-ever infarct, and 62 patients had a recurrent infarct. First of all we performed a linear regression analysis in which we entered age, gender and stroke type (first-ever infarct versus recurrent infarct) as independent variables and the 
first BP as dependent variable. This analysis showed no significant association between the two stroke types and the level of admission BP. For this reason, we used the first and recurrent infarcts together for the remaining analyses.

Table 2 shows associations between several independent variables and the level of the different BP variables. For every year of life, the SBP rose $0.7 \mathrm{mmHg}$. BP was significantly higher in males than in females. Patients with IHD had significantly lower first BP. Patients known with hypertension had a significantly higher SBP than patients without. Patients with asymptomatic lacunar infarcts on CT had higher first BP. Stroke type (LACI vs CE and vs AT) had no significant relationship with the level of first BP.

Table 2: Association between several independent variables and the level of the BP measured within the first 24 hours after admittance $(N=271)$. Data are linear regression coefficient for the associations.

\begin{tabular}{lllll}
\hline & SBP & P-value & DBP & P-value \\
\hline Age (years) & 0.7 & 0.0001 & - & ns \\
Gender: male & 11.2 & 0.03 & 7.0 & 0.003 \\
IHD & -10.3 & 0.02 & -5.5 & 0.02 \\
HT & 9.5 & 0.03 & - & ns \\
Asymptomatic lacunar & & & & \\
$\quad$ infarcts on CT & 10.2 & 0.04 & 9.2 & 0.003 \\
\hline
\end{tabular}

Figure 1 illustrates the relationship between the logOdds (Rankin at six months $>3$ vs $\leq$ 3 ) and the first systolic BP. According to the plot, cut-off SBP values that were used for further analyses were chosen as 135 and $155 \mathrm{mmHg}$. When fed into the logistic regression analyses, these values did not show a significant relationship with the outcome at six months. Shifting the cut-off points by adding or subtracting $5 \mathrm{mmHg}$ did not reveal any significant relationship with outcome either (table 3). Similar analyses for DBP showed no significant relationship with outcome. 
Fig.1: The logOdds of the moving average of the dichotomized Rankin ( $>3$ vs $\leq 3)$ plotted against the SBP

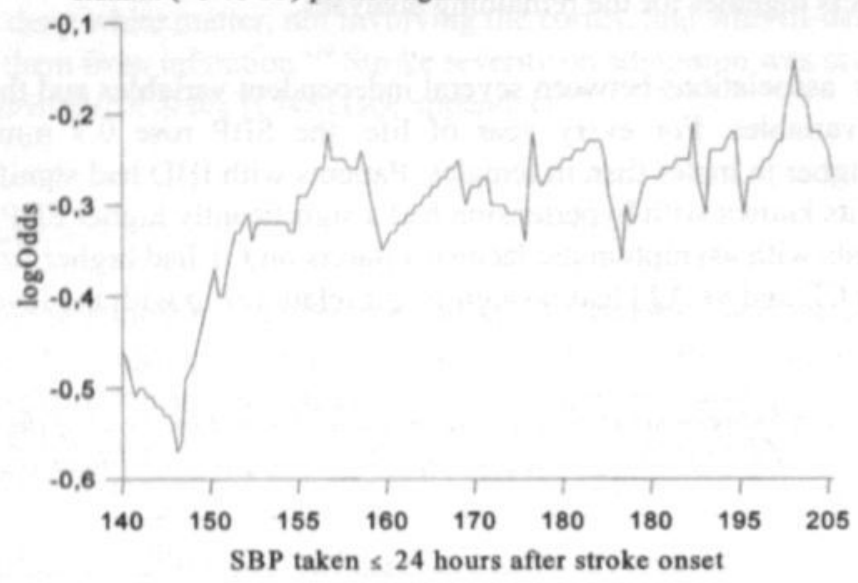

Table 3: Relationship between first BP variables registered within 24 hours following stroke onset and outcome at 6 months: Rankin $>3$ vs $\leq 3$.

\begin{tabular}{lllll}
\hline First BP-values $(\mathrm{mmHg})$ & OR & $95 \% \mathrm{Cl}$ & P-value \\
\hline \multirow{2}{*}{ SBP } & $\leq 135(\mathrm{~N}=32)$ vs $136-154(\mathrm{~N}=59)$ & 0.4 & $0.1-1.4$ & $\mathrm{~ns}$ \\
& $2155(\mathrm{~N}=180)$ vs $136-154$ & 0.7 & $0.3-1.6$ & ns \\
DBP $\leq 80(\mathrm{~N}=72)$ vs $81-99(\mathrm{~N}=85)$ & 2.0 & $0.9-4.4$ & ns \\
& $2100(\mathrm{~N}=114)$ vs $81-99$ & 1.5 & $0.7-3.1$ & ns \\
\hline
\end{tabular}

Abbreviations: $O R=$ odds ratio, $C I=$ confidence interval

Figure 2 illustrates the relationship between the logOdds and the first systolic BP for a subgroup of patients who were admitted to the hospital within 3 hours after stroke onset $(\mathrm{N}=138)$. This plot suggests that particularly high SBP values are associated with poor outcome (Rankin score $>3$ ). However when fed into the multivariate logistic regression analyses, these values did not show a significant relationship with outcome at 6 months (see table 4). Similarly, there was no significant relationship with outcome for first DBP values measured within 3 hours after stroke onset. 
Fig.2: The logOdds of the moving average of the dichotomized

Rankin ( $>3$ vs $\leq 3)$ plotted against the SBP

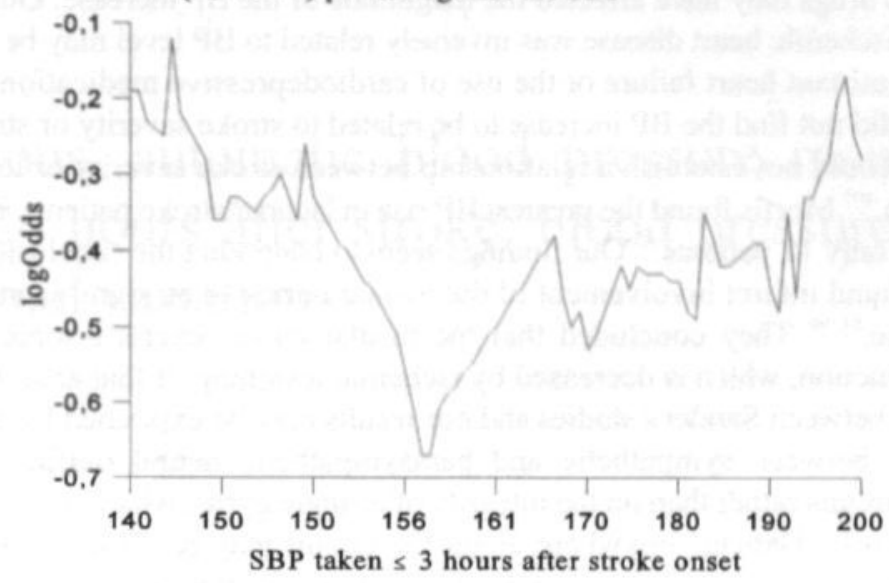

Table 4: Relationship between first BP variables registered within 3 hours following stroke onset and outcome at 6 months: Rankin $>3 v s \leq 3$.

\begin{tabular}{lllll}
\hline First BP-values $(\mathrm{mmHg})$ & OR & $95 \% \mathrm{CI}$ & P-value \\
\hline \multirow{2}{*}{ SBP } & $\leq 150(\mathrm{~N}=53)$ vs $151-169(\mathrm{~N}=19)$ & 1.8 & $0.5-6.7$ & $\mathrm{~ns}$ \\
& $\geq 170(\mathrm{~N}=66)$ vs $151-169$ & 1.6 & $0.4-6.3$ & $\mathrm{~ns}$ \\
DBP & $\leq 90(\mathrm{~N}=75)$ vs $91-109(\mathrm{~N}=39)$ & 1.7 & $0.7-4.3$ & $\mathrm{~ns}$ \\
& $\geq 110(\mathrm{~N}=24)$ vs $91-109$ & 1.5 & $0.4-5.3$ & $\mathrm{~ns}$ \\
\hline
\end{tabular}

Abbreviations: $\mathrm{OR}=$ odds ratio, $\mathrm{CI}=$ confidence interval

\section{Discussion}

We studied factors related to admission BP level within 24 hours following ischemic stroke, and whether or not the level of BP is an independent predictor of outcome at six months. We found known hypertension and silent lacunar infarcts to be independently associated with BP level. Others also found known hypertension as a strong predictor of raised post-stroke BP ${ }^{5354}$ Various factors may contribute to the BP rise, such as 'mental stress', ${ }^{46} 106-108$ elevated cortisol levels, ${ }^{61} 90109$ impaired cardiac baroreceptor sensitivity, ${ }^{539597}$ and sympathetic-parasympathetic imbalance. ${ }^{91}$ Patients with hypertension may be more prone to act with sympathetic overshoot, or be more liable to increased sympathetic activity. ${ }^{96}$ There may be a sex difference in this respect, as we found BP level to be associated with male gender. Antihypertensive treatment does not seem to alter the 
increased response of BP, as such treatment was not related to admission BP level in our patients. However, we cannot exclude the possibility that depending on their mode of action, some drugs may have affected the magnitude of the BP increase. Our finding that a history of ischemic heart disease was inversely related to BP level may be explained by latent concomittant heart failure or the use of cardiodepressive medication.

We did not find the BP increase to be related to stroke severity or stroke subtype. Others also could not establish a relationship between stroke severity or lesion size and BP elevation. ${ }^{107}$ Morfis found the greatest BP rise in lacunar stroke patients, but this group consisted of only 18 patients. ${ }^{60}$ Our findings seem to contradict the conclusions of Sander et al. who found infarct involvement of the insular cortex to be significantly associated with BP rise. ${ }^{91} 96$ They concluded that the insular cortex exerts a tonic sympathetic inhibitory function, which is decreased by ischemic lesioning of that area. However, the discrepancy between Sander's studies and our results may be explained by assuming that the balance between sympathetic and parasympathetic neural outflow depends on regulatory circuits rather than on the integrity of a single gyrus, which may, however, play a dominant role. Damage anywhere along the circuit may result in a disbalance. Our finding that leukoaraiosis and especially 'silent' lacunar infarcts were associated with a higher BP may support this contention. A more detailed clinico-anatomical correlation study may provide further evidence in this respect (see chapter 7).

Various studies have related admission BP to outcome. ${ }^{42} 46485070-77$ Few also analysed BP as an independent predictor, accounting for differences in other important prognostic variables. ${ }^{46} 48727677$ Some studies looked at short term stroke deterioration, which may not necessarily predict eventual functional outcome. ${ }^{46} 75$ Chamorro, in a series of 481 ischemic stroke patients, found higher mean BP at baseline to be independently related to good functional outcome at one week. ${ }^{64}$ On the contrary, Robinson found a worse 30-day functional outcome in 136 patients with elevated admission BP. ${ }^{48}$ In our 271 ischemic stroke patients, we found no significant association between the admission $\mathrm{BP}$ and outcome at six months when data were adjusted for possible confounders. When we restricted the analysis to patients admitted within 3 hours, the moving average plot suggested a $U$ shape relation between $\mathrm{BP}$ and outcome, but multivariate regression analysis did not show a relationship between this BP and functional outcome at six months. Theoretically, low BP may, in the presence of impaired autoregulation, lead to hypoperfusion in a threatened penumbra, ${ }^{414247.52}$ whereas elevated BP may lead to edema formation and hemorrhagic transformation, thereby increasing tissue destruction. ${ }^{43} 4647$ Our data do not support the idea of a simple, general treatment modality for all stroke patients. According to our U-shaped moving average plots, they rather suggest that elevation of low BP and lowering of high BP should be tested separately. BP values in the intermediate range may not be amenable for therapeutic intervention. A limitation of our study is its relative small size, especially when testing three separate groups based on BP level and therefore our results have to be confirmed or refuted by larger series. Results from the BASC initiative will be most important in this respect. ${ }^{126}$ 
5

Continuous, automatic blood pressure monitoring within 24 hours after stroke: blood pressure levels and diurnal variations 


\section{Abstract}

\section{Background}

Diurnal blood pressure (BP) variation changes after acute stroke. There are indications that nighttime BP dipping is absent in acute stroke, but it is not clear how often this occurs or what its significance is. It is also not clear whether or not absence of dipping depends on stroke severity or stroke subtype. Therefore, we performed 24-hour BP monitoring to study diurnal BP variation in acute stroke. We also studied various factors potentially related to the degree of BP variation in acute stroke.

\section{Methods}

Twenty-four hour BP values were collected prospectively in 271 patients, admitted within 24 hours following stroke onset. We explored the following variables: the first measured systolic and diastolic BP values of the 24-hour BP measurements, mean 24-hour systolic (24-hour SBP) and diastolic BP, daytime and nighttime systolic and diastolic BP, and absolute and percentage variation in systolic and diastolic BP.

\section{Results}

Mean 24-hour BP profiles were similar for all stroke subgroups. Lacunar infarct patients had significantly higher 24-hour and daytime systolic and diastolic BP than cardioembolic infarct patients. Furthermore, they had significantly higher absolute and percentage systolic and diastolic BP variation than cardioembolic and atherothrombotic infarct patients. Diurnal BP variation was decreased in most acute stroke patients. Lacunar infarct patients showed significantly more often a 'dipping' pattern in diastolic BP than the other two stroke subgroups. Patients with asymptomatic lacunar infarcts on CT showed a significant higher diurnal BP variation, and patients with a Rankin score 5 at admission showed a significant lower diurnal BP variation.

\section{Conclusion}

Although diurnal BP variation is decreased in most acute stroke patients, differences in diurnal BP variation exist between infarct subgroups. Especially lacunar stroke and the presence of one or more asymptomatic lacunar lesions on CT are associated with larger diurnal BP variation. We hypothesize that lacunar stroke may not be causally related to hypertension. Aggressive treatment of hypertension as a secondary preventive measure may cause, rather than prevent, ischemic lesion progression in the brain of especially lacunar stroke patients. 


\section{Introduction}

Blood pressure (BP) levels are elevated within the first 24 hours following stroke onset in over $70 \%$ of acute stroke patients. ${ }^{53-58}$ This high BP tends to decrease spontaneously during the first 10 days following stroke onset. ${ }^{55}$ Diurnal BP variation can be studied by automatic 24-hour BP monitoring. ${ }^{489} \mathrm{It}$ is well known that there is a diurnal pattern of $\mathrm{BP}$ change, with morning values being higher than those recorded in the evening, and a decrease (dip) during nighttime. ${ }^{78-82}$ Several definitions have been used to define this 'dipping', including an absolute $10 \mathrm{mmHg}$ day minus night systolic or diastolic BP fall, or a $10 \%$ systolic or diastolic BP decrease. ${ }^{34}{ }^{85}$ However, it should be realized that the magnitude of diurnal BP variation that is called 'dipping' is chosen rather arbitrarily. Patients with lesser falls in nocturnal BP, are called 'nondippers'.53 878 Stroke patients, for instance, often display reduced diurnal BP variation in the acute phase of stroke. ${ }^{5981} 8691$ However, most studies on diurnal BP rhythm after stroke used small patient numbers, ${ }^{9-97}$ or included patients later than 24 hours following stroke onset. ${ }^{53929397}$ Furthermore, in most studies BP measurements during the transition hours between daytime and nighttime levels were included in the analyses, which artificially blunts the degree of BP fall during nighttime. ${ }^{59} 698692-9498-100$ Therefore, although there are some indications that diurnal BP variation is decreased in acute stroke, it is far from clear how often this occurs or what its prognostic significance is. It is also not clear whether the degree of diurnal BP variation in acute stroke depends on stroke severity or stroke type.

Answers to these questions may give more insight into early BP regulation in acute stroke and its possible effect on cerebral perfusion and eventual stroke outcome. Therefore, in 192 patients with acute ischemic stroke, we performed 24-hour BP monitoring to study diurnal BP variation. We also studied various factors potentially related to the degree of diurnal BP variation in acute stroke.

\section{Patients and Methods}

\section{Data collection}

Between 1 January 1996 and 1 March 2000, data of patients with a stroke who were admitted to our hospital or visited the outpatient's clinic, were prospectively collected in an ongoing stroke registry at the University Hospital of Maastricht. The University Hospital is the only hospital in the Maastricht region and has an adherent population of approximately 200,000 people. Routine investigations included standard blood tests, electrocardiogram, chest X-ray, brain CT scan and carotid artery ultrasound studies. Echocardiography, 24-hour ECG monitoring and cerebral angiography were done in selected cases.

In this prospective study, 676 patients with ischemic stroke were admitted to our stroke unit within 24 hours following stroke onset. 516 patients of this group had a first brain infarct, whereas 160 patients had a recurrent infarct. In 271 of these 676 patients we prospectively collected 24 -hour BP values. This 24 -hour BP monitoring was started 
within the first 24 hours following stroke onset. We used an oscillometric HP M1205 Omnicare CMS monitor. The monitor was programmed to record at 30-minute intervals. The fact that of the 676 patients only $271(40 \%)$ entered the study was mainly due to the availability of only two automatic BP monitoring devices. To compare daytime with nighttime BP level, and to prevent any influence from BP changes during the transition hours, we took those BP measurements that were recorded between $9.00 \mathrm{~h}$ and $18.00 \mathrm{~h}$ as daytime BP values and BP measurements that were recorded between $24.00 \mathrm{~h}$ and $06.00 \mathrm{~h}$ as nighttime BP values. Furthermore, we only used those patients in whom over $80 \%$ data capture had been achieved, leaving 192 patients for our study.

\section{Blood pressure variables}

We explored the following variables:

- the first systolic (first SBP) and diastolic (first DBP) BP measured with the BP monitor. - the mean 24-hour systolic (24-hour SBP) and diastolic (24-hour DBP) BP: the sum of all systolic or diastolic BP values divided by the total number of BP measurements during the first 24 hours.

- mean daytime systolic (daytime $S B P$ ) and diastolic (daytime $D B P$ ) $\mathrm{BP}$ as described above.

- mean nighttime systolic (nighttime SBP) and diastolic (nighttime DBP) BP as described above.

- absolute variation in diurnal systolic BP (abs $S B P$ ): the difference between the mean daytime systolic and mean nighttime systolic BP.

- absolute variation in diurnal diastolic BP (abs DBP): the difference between the mean daytime diastolic and mean nighttime diastolic BP.

- percentage variation in diurnal systolic BP (perc SBP): the difference between the mean daytime systolic and mean nighttime systolic BP divided by the mean daytime systolic BP multiplied by $100 \%$.

- percentage variation in diurnal diastolic BP (perc DBP): the difference between the mean daytime diastolic and mean nighttime diastolic BP divided by the mean daytime diastolic BP multiplied by $100 \%$.

\section{Definitions}

Hypertension (HT) was defined as known hypertension (blood pressure recordings of more than $140 \mathrm{mmHg}$ systolic and/or $90 \mathrm{mmHg}$ diastolic pressure on at least two different occasions) whether or not treated with antihypertensive medication before the stroke. ${ }^{127}{ }^{128}$ Patients without known BP values, were considered hypertensive when treated with antihypertensive drugs.

Diabetes mellitus ( $D M$ ) was defined as known diabetes treated with diet or medication, or either a fasting blood glucose higher than $7 \mathrm{mmol} / \mathrm{l}$ or a postprandial blood glucose 
higher than $11 \mathrm{mmol} /$, measured on at least two separate occasions before or at least one week after the stroke.

Ischemic heart disease (IHD) was defined as a history of angina pectoris, myocardial infarction or coronary bypass surgery.

A brain infarct was defined as the rapid onset of clinical signs of focal cerebral function disturbance, lasting longer than 24 hours or leading to death, with no apparent cause other than that of vascular origin, with normal CT or CT showing an area of low attenuation compatible with the clinical signs and symptoms, or autopsy revealing an infarct compatible with the clinical signs and symptoms.

A lacunar infarct $(\mathrm{LACl})$ was defined as an acute stroke syndrome with a CT lesion compatible with occlusion of a single perforating artery, i.e., a small, subcortical, sharply marginated hypodense lesion with a diameter smaller than $15 \mathrm{~mm}$ (small deep infaret), or as a specific lacunar syndrome (i.e., unilateral motor and/or sensory symptoms and signs that completely involved at least 2 of 3 body parts (face, arm, and leg) without disturbance of consiousness or language, visual field defect, or other signs of cortical dysfunction) when the CT scan showed no specific lesion. A potential cardioembolic stroke cause was not taken into account when assigning patients to this infarct subgroup. A territorial infarct was defined as an acute stroke syndrome with CT findings compatible with infarction involving the cortex, or when no specific lesion was visible on CT, as a clinically identified cortical syndrome consisting of unilateral motor and/or sensory symptoms and signs in combination with signs of cortical dysfunction with or without visual field defect, or as isolated monoparesis or as isolated cortical dysfunction (usually dysphasia). Patients with a large subcortical infarct or (non-lacunar) brainstem infarct were included in the territorial infarct group because of similar pathogenesis.

Territorial infarct patients with a potential cardioembolic stroke source were assigned to the cardioembolic stroke subgroup (CE). Such patients had at least one of the following cardiac features: chronic or intermittent ECG confirmed atrial fibrillation; left ventricular myocardial infarction within six weeks preceding stroke; left ventricular or atrial thrombus; left ventricular aneurysm; left ventricular akinetic segment; cardiomyopathy; mitral or aortic valve abnormalities (endocarditis, mitral stenosis, prosthetic aortic or mitral valves); and in young patients without any other specific stroke cause: atrial septal defect, ventricle septal defect. Patients with a non-cardioembolic symptomatic territorial infarct (presumably large vessel disease, i.e. atherothrombosis or artery-to-artery embolism whether or not confirmed by non-invasive carotid studies) were assigned to the atherothrombotic infarct subgroup (AT). Patients with a 'rare' stroke cause, such as arterial dissection, vasculitis, fibromuscular dysplasia, hematological disorder, etc. were not included in the study because of small numbers and heterogeneity in stroke cause.

An infarct was considered asymptomatic if located in an area that could not account for the neurological signs and symptoms, whereas the radiologically estimated age was not consistent with the time of clinical symptoms of the index stroke (old lesions being more hypodense, more sharply delineated, or showing signs of retraction of brain structures towards the lesion site on CT).

Leukoaraiosis (LA) on CT was defined as focal or diffuse hypodensities in the 
Figure 2 shows the mean 24-hour systolic BP profiles, for the first 24 hours following stroke onset for the different stroke subgroups. The BP profiles were quite similar in all three groups, again with lowest BP values during the nighttime hours and resting hours during the daytime (around $14.00 \mathrm{~h}$ ). The diastolic BP showed similar mean 24-hour BP profiles for the three subgroups (figure 3 ).

Fig. 2: SBP during the first 24 hours following stroke

for the different stroke subgroups

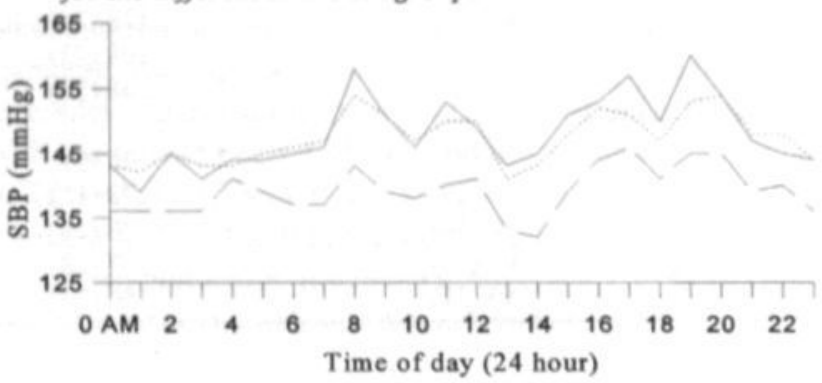

LACI $(\mathrm{N}=45)$

$\mathrm{CE}(\mathrm{N}=37)$

AT $(\mathrm{N}=110)$

Fig.3: DBP during the first 24 hours following stroke

for the different stroke subgroups

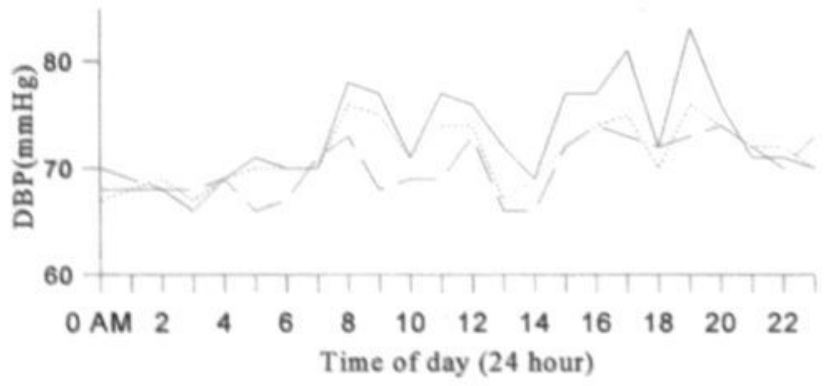

$$
\begin{aligned}
& \text { LACI }(\mathrm{N}=45) \\
& \text { CE }(\mathrm{N}=37) \\
& \text { AT }(\mathrm{N}=110)
\end{aligned}
$$


Table 2 shows the different BP values for the total stroke group and the different stroke subgroups, and absolute and percentage systolic and diastolic diurnal BP variation. The first measured BP values were significantly higher than the mean of the 24-hour BP values (paired samples,T-test). Lacunar infarct patients had significantly higher 24-hour and daytime systolic and diastolic BP than cardioembolic infarct patients. Furthermore, lacunar infarct patients had significantly higher absolute and percentage systolic and diastolic BP variation than cardioembolic and atherothrombotic infarct patients (independent samples T-test).

Table 2: Baseline blood pressure characteristics for all patients and the different stroke subgroups.

\begin{tabular}{lllll}
\hline & $\begin{array}{l}\text { Total group } \\
(\mathrm{N}=192)\end{array}$ & $\begin{array}{l}\text { Laci } \\
(\mathrm{N}=45)\end{array}$ & $\begin{array}{l}\mathrm{Ce} \\
(\mathrm{N}=37)\end{array}$ & $\begin{array}{l}\text { At } \\
(\mathrm{N}=110)\end{array}$ \\
\hline SBP (mmHg) & & & & \\
First SBP & $158 \pm 32(72-243)$ & $163 \pm 30$ & $153 \pm 36$ & $159 \pm 31$ \\
24-hour SBP & $146 \pm 22(98-216)$ & $149 \pm 22$ & $140 \pm 19$ & $147 \pm 23$ \\
Daytime SBP & $147 \pm 22(99-211)$ & $151 \pm 21$ & $140 \pm 20$ & $147 \pm 23$ \\
Nighttime SBP & $142 \pm 25(94-210)$ & $143 \pm 26$ & $137 \pm 21$ & $144 \pm 25$ \\
& & & & \\
DBP (mmHg) & & & $79 \pm 21$ & $78 \pm 18$ \\
First DBP & $78 \pm 18(39-157)$ & $78 \pm 13$ & $70 \pm 12$ & $71 \pm 11$ \\
24-hour DBP & $71 \pm 11(42-115)$ & $73 \pm 12$ & $72 \pm 12$ \\
Daytime DBP & $73 \pm 12(43-121)$ & $76 \pm 12$ & $70 \pm 13$ & $72 \pm 12$ \\
Nighttime DBP & $68 \pm 13(40-100)$ & $68 \pm 14$ & $68 \pm 13$ & $69 \pm 17$ \\
& & & & $3 \pm 15$ \\
abs SBP & $4 \pm 16(-50-+58)$ & $9 \pm 15$ & $3 \pm 11$ \\
perc SBP & $3 \pm 11(-37-+31)$ & $6 \pm 10$ & $2 \pm 10$ & $2 \pm 11$ \\
abs DBP & $4 \pm 10(-18-+37)$ & $8 \pm 9$ & $2 \pm 10$ & $4 \pm 9$ \\
perc DBP & $5 \pm 13(-32-+37)$ & $10 \pm 11$ & $2 \pm 15$ & $4 \pm 13$ \\
\hline
\end{tabular}

Results are mean $\pm S D$ (range)

Table 3 shows the systolic and diastolic diurnal variation for all patients and the different stroke subgroups, separately for those with known hypertension before stroke and those without. Patients with known hypertension before stroke did not show a statistically significant difference in systolic or diastolic diurnal variation compared to patients who were not known with hypertension before stroke (independent samples T-test). The absolute systolic and diastolic diurnal BP variation of lacunar infarct patients known with hypertension was significantly higher than atherothrombotic patients known with hypertension. Furthermore, the percentage diastolic diurnal BP variation of lacunar infarct patients known with hypertension was significantly higher than atherothrombotic or cardioembolic infarct patients, known with hypertension (independent samples T-test). This shows that the greatest degree of diurnal variation was found in patients with lacunar stroke, especially those patients known with hypertension before stroke. 
Table 3: Systolic and diastolic diurnal variation for patients known with hypertension before stroke and patients not known with hypertension before stroke.

\begin{tabular}{|c|c|c|c|c|}
\hline & $\begin{array}{l}\text { Total group } \\
(\mathrm{N}=192)\end{array}$ & $\begin{array}{l}\text { Laci } \\
(\mathrm{N}=45)\end{array}$ & $\begin{array}{l}\mathrm{Ce} \\
(\mathrm{N}=37)\end{array}$ & $\begin{array}{l}\text { At } \\
(\mathrm{N}=110)\end{array}$ \\
\hline abs SBP, HT+ & $4 \pm 17(-42-+42)$ & $10 \pm 19$ & $0 \pm 17$ & $2 \pm 16$ \\
\hline pere SBP, HT+ & $2 \pm 11(-37-+25)$ & $7 \pm 12$ & $0 \pm 11$ & $1 \pm 11$ \\
\hline abs SBP, HT- & $5 \pm 16(-50-+58)$ & $7 \pm 12$ & $4 \pm 14$ & $4 \pm 18$ \\
\hline perc SBP, HT- & $3 \pm 10(-35-+31)$ & $5 \pm 8$ & $2 \pm 10$ & $2 \pm 11$ \\
\hline abs DBP, HT + & $4 \pm 11(-17-+37)$ & $9 \pm 12$ & $1 \pm 12$ & $3 \pm 9$ \\
\hline pere DBP, HT + & $5 \pm 14(-30-+37)$ & $12 \pm 14$ & $-1 \pm 18$ & $4 \pm 13$ \\
\hline abs DBP, HT- & $5 \pm 9(-18-+24)$ & $7 \pm 7$ & $3 \pm 9$ & $4 \pm 10$ \\
\hline pere DBP, HT- & $6 \pm 13(-32-+31)$ & $9 \pm 9$ & $3 \pm 13$ & $5 \pm 14$ \\
\hline
\end{tabular}

Results are mean $\pm S D$ (range)

Table 4 shows the number of patients per stroke subgroup when the different diurnal BP variations are divided according to the definitions of 'dipping'. Univariate logistic regression analyses showed that patients with a lacunar infarct were significantly stronger related to an absolute diastolic BP variation $\geq 10 \mathrm{mmHg}$ than patients with a territorial infarct : OR 2.7; $95 \% \mathrm{CI} 1.3-5.4$. This was also the case regarding a percentage diastolic BP variation $\geq 10 \%$ : OR 3.1; $95 \% \mathrm{CI} 1.6-6.2$.

Table 4: Number of patients with 'dipping' and 'non-dipping' per stroke subgroup.

\begin{tabular}{|c|c|c|c|c|}
\hline & & $\begin{array}{l}\text { Laci }(\mathrm{N}=45) \\
\mathrm{N}(\%)\end{array}$ & $\begin{array}{l}\mathrm{Ce}(\mathrm{N}=37) \\
\mathrm{N}(\%)\end{array}$ & $\begin{array}{l}\text { At }(\mathrm{N}=110) \\
\mathrm{N}(\%)\end{array}$ \\
\hline \multirow[t]{2}{*}{ abs SBP } & $<10 \mathrm{mmHg}$ & $26(58)$ & $22(59)$ & $76(69)$ \\
\hline & $\geq 10 \mathrm{mmHg}$ & $19(42)$ & $15(41)$ & $34(31)$ \\
\hline \multirow[t]{2}{*}{ pere SBP } & $<10 \%$ & $32(71)$ & $32(86)$ & $88(80)$ \\
\hline & $\geq 10 \%$ & $13(29)$ & $5(14)$ & $22(20)$ \\
\hline \multirow[t]{2}{*}{ abs DBP } & $<10 \mathrm{mmHg}$ & $24(53)$ & $29(78)$ & $82(75)$ \\
\hline & 之 $10 \mathrm{mmHg}$ & $21(47)$ & $8(22)$ & $28(25)$ \\
\hline \multirow[t]{2}{*}{ pere DBP } & $<10 \%$ & $19(42)$ & $25(68)$ & $77(70)$ \\
\hline & $z 10 \%$ & $26(58)$ & $12(32)$ & $33(30)$ \\
\hline
\end{tabular}


Table 5 shows the association between several independent variables and the absolute variation in diurnal systolic and diastolic BP. Per one year ageing, the absolute variation in systolic BP significantly declined with $0.25 \mathrm{mmHg}$. Lacunar infarct was independently associated with a higher diurnal variation compared to the remaining infarets. A Rankin score of 5 at stroke onset was independently associated with a smaller diurnal BP variation; in accordance with this, a CNS score higher than 8 compared to a score $\leq 2$ was independently associated with a larger diurnal BP variation. Furthermore, the presence of one or more asymptomatic lacunar infarcts on CT was independently associated with higher diurnal BP variation.

Table 5: Association between several independent variables and absolute diurnal variation of systolic and diastolic BP. Data are linear regression coefficient for the associations.

\begin{tabular}{rllll}
\hline Dependent variables & $\begin{array}{l}\text { Coefficient } \\
\text { abs SBP }\end{array}$ & $\begin{array}{l}\text { P-value } \\
\text { abs SBP }\end{array}$ & $\begin{array}{l}\text { Coefficient } \\
\text { abs DBP }\end{array}$ & $\begin{array}{l}\text { P-value } \\
\text { abs DBP }\end{array}$ \\
\hline Stroketype: Ce vs Laci & -2.9 & ns & -2.2 & ns \\
At vs Laci & -1.6 & ns & -0.7 & ns \\
Ce + At vs Laci & -5.2 & ns & -4.0 & 0.02 \\
IHD & -1.7 & ns & 0.2 & ns \\
DM & -0.9 & ns & -0.5 & ns \\
Age & -0.25 & 0.04 & -0.8 & ns \\
Sex & 0.5 & ns & -0.5 & ns \\
HT & 0.6 & ns & 0.7 & ns \\
asympt. Laci's on CT & 7.1 & 0.03 & 4.7 & 0.02 \\
Rankin at stroke onset: & & & & \\
$\quad 3$ vs 1,2 & 2.0 & ns & 3.7 & ns \\
$\quad 4$ vs 1,2 & -3.2 & ns & -1.5 & ns \\
5 vs 1,2 & -4.6 & 0.045 & -3.1 & 0.01 \\
CNS at admission: & & & & \\
$>2$ and $\leq 4$ vs $\leq 2$ & 0.8 & ns & -0.3 & ns \\
$>4$ and $\leq 6$ vs $\leq 2$ & -3.7 & ns & -2.6 & ns \\
$>6$ and $\leq 8$ vs $\leq 2$ & -0.7 & ns & 0.4 & ns \\
$>8$ and $\leq 10$ vs $\leq 2$ & 5.6 & 0.03 & 3.4 & 0.02 \\
\hline
\end{tabular}

\section{Discussion}

The present study analysed various BP variables and diurnal BP variation in 192 ischemic stroke patients, admitted within 24 hours following stroke onset. Automatic BP recording devices were used for continuous 24-hour BP registration. We found that the first measured BP values were higher than the mean of the 24-hour BP values. This finding was similar in the three stroke subgroups. Lip et al. ${ }^{59}$ also found higher initial values compared 
to mean 24-hour BP values. One could postulate that reliance on a single, first BP value with respect to prognosis, for example, may overestimate the impact of such first BP value. Similar reasoning applies when acute BP treatment is considered, in which case it may be better to stay conservative and monitor BP carefully, awaiting spontaneous BP decline. With respect to prognosis, it is currently unclear whether or how elevated BP in acute stroke should be treated to improve prognosis. However, considering that the time window for therapeutic measures is likely to be limited, prognosis might still best be studied in relation to the first measured BP value from a pragmatical point of view.

A second finding was that BP dipping, defined as an absolute or percentage nocturnal BP drop of $10 \mathrm{mmHg}$ or $10 \%$, respectively, significantly more often occurred in the lacunar stroke group. This may relate to our finding that stroke severity was associated with a lower degree of diurnal BP variation. Indeed, lacunar strokes are on average less severe than cardioembolic or atherothrombotic strokes. Stroke severity and a higher age may decrease circadian BP variation. Fujishima et al. investigated the diurnal variation in lacunar stroke patients. ${ }^{90}$ They found a non-dipping pattern in the acute phase of lacunar stroke and speculated that this could be caused by either increased secretion of epinephrine and cortisol in the acute stroke phase, or by some compensatory mechanism that may raise $\mathrm{BP}$ in order to protect the brain from ischemia. Their study group, however, was very small: only 7 patients. Others found reduced BP variation to be associated with more advanced cerebrovascular damage, as expressed by the presence of asymptomatic (silent) lacunar infarcts on CT. ${ }^{88} 89104$ These studies, however, focussed on the consequenses of a diminished nocturnal $\mathrm{BP}$ fall and associated these lacunar infarcts with hypertensive end-organ damage. In contrast, we found silent lacunar infarcts on CT to be related to a larger diurnal BP variation. This finding concurs with the tendency of a higher degree of diurnal BP variation in the hypertensive lacunar stroke patient group. These findings are puzzling, because in general, end-organ damage is associated with diminished BP dipping, and especially lacunar infarcts with one or more concomittant silent small deep lesions are strongly related to hypertension. So, the finding of an association between lacunar stroke, and specially those with silent lesions and large diurnal BP variation is quite opposite to what one would expect. One could hypothesize that lacunar stroke and silent lacunes, although both are independently related to hypertension, are not, or at least not completely, caused by the hypertension itself. Instead, hypertension and cerebral small vessel disease, notably small vessel arteriolosclerosis, may have a common cause. Our earlier findings are in line with this idea, since asymptomatic lacunar infarcts, but also leukoaraiosis progress over time despite measures of secondary stroke prevention, such as treatment of hypertension. ${ }^{141}$ If hypertension and small vessel arteriolosclerosis have one or more causal factors in common, this may imply that certain determinants of hypertension may also explain the nature of cerebral small vessel arteriolosclerosis. A comparative study on the degree of diurnal BP variation, especially the frequency of nocturnal BP dipping in various subgroups of patients with hypertension, and relation to the presence of leukoaraiosis or silent ischemic lesions, may clarify this point. 
Watanabe et al. postulated that hypertension treatment in dippers may lower nighttime BP values below the limit where sufficient cerebral perfusion pressure can be maintained, and that this could lead to ischemic lesions. ${ }^{103}$ If so, diligent treatment of hypertension may enhance, rather than prevent, the development of small deep lesions and leukoaraiosis in patients with cerebral small vessel arteriolosclerosis. However, another possibility to explain the larger diurnal BP variation in the lacunar infarct group is that these patients may have had a more physiological sleeping pattern, as opposed to patients with more extended cerebral damage, in whom sleep can be severely disturbed. ${ }^{142-144} \mathrm{~A}$ third possibility may be that territorial stroke has a stronger impact on diminishing diurnal BP variation than lacunar stroke. As we have no information of prior stroke diurnal variation in our patients, we cannot refute the possibility that the eventual territorial stroke patients had even larger variation, or had more dippers among them than those who ultimate sustained lacunar stroke.

Our study has further limitations. First of all, we were able to investigate only $40 \%$ of our eligible population. This was mainly due to the limited availability of the automatic $\mathrm{BP}$ recording devices. However, comparison of patient characteristics of those included and those who were not showed that the groups were rather similar, although the study group included somewhat more males and patients with known hypertension. This may have biased our study towards the inclusion of more patients with higher BP values after stroke, as we found both male gender and known hypertension to be related to higher initial BP levels following stroke. However, overall the groups were quite similar, so that major bias is unlikely. Another point that could be critisized is the inclusion of patients with recurrent stroke. Although BP values were somewhat higher in patients with recurrent stroke than in those with first stroke, 24-hours BP patterns were similar between these groups. Furthermore, recurrent stroke was not independently related to diurnal BP variation. Therefore, the inclusion of recurrent strokes in our series is unlikely to have created bias towards the detection of a larger diurnal BP variation. Lago et al. also found no difference between the diurnal patterns of first and recurrent stroke. ${ }^{81}$

The main conclusion from our study is that, although most patients showed a reduced diurnal BP variation, the degree of diurnal BP variation was the highest in lacunar stroke patients. As also silent lesions on CT were related to higher diurnal BP variation, we hypothesize that hypertension and cerebral small vessel disease, especially small vessel arteriolosclerosis, are not directly causally related. Instead, both may have a common underlying cause. In general, the absence of BP dipping is associated with an increased risk of hypertensive end- organ damage. ${ }^{89} 98101103$ Whether the absence of dipping in the acute phase of stroke has any independent prognostic value, or whether it is merely an integral part of the acute stroke syndrome, is unclear. Therefore, this question will be addressed in the next chapter. 
6

Blood pressure level and diurnal variation do not predict stroke outcome 


\begin{abstract}
Background

Manipulation of blood pressure (BP) in acute stroke may improve outcome. Data on the prognostic significance of early BP, or 24-hour BP values and diurnal BP variation after acute stroke, remain unclear. We explored whether various BP variables, including diurnal BP variation, are independent predictors of stroke outcome.
\end{abstract}

\title{
Methods
}

24-hour BP values were collected prospectively with an automatic monitoring device in 271 patients admitted to our stroke unit within 24 hours following ischemic stroke onset. We studied the first measured systolic and diastolic BP of the 24-hour registration, the mean daytime and nighttime systolic and diastolic BP, the absolute and percentage diurnal variation in systolic and diastolic BP and finally, the fall in systolic and diastolic $\mathrm{BP}$ in the first four days following stroke onset. As dependent outcome variable we used the Rankin handicap score at six months, dichotomized in a Rankin $>3$ as poor and a Rankin $\leq 3$ as good outcome.

\section{Results}

We only found a first diastolic BP $\leq 70 \mathrm{mmHg}$ to be significantly related to poor functional outcome at six months (OR 2.3; $95 \%$ CI 1.0-5.5). The other BP variables, including diurnal BP variation and the fall in BP during the first four days following stroke onset, did not show a significant relationship with outcome.

\section{Conclusion}

Our findings suggest that in the vast majority of ischemic stroke patients, BP values are in a range that does not jeopardize penumbral tissue. When testing any acute stroke trial on early BP manipulation, it should only be done in pre-defined subgroups, existing out of patients with very high or very low BP values. 


\section{Introduction}

Blood pressure (BP) is often elevated in acute stroke. ${ }^{53-58}$ The mechanism of this BP elevation in stroke is still unclear: acute BP elevation may be the cause of stroke in some cases, a result of the stroke, or an epiphenomenon associated with the stroke process. ${ }^{69}$ It is also still unclear whether BP in the acute phase of stroke is related to stroke outcome. Ideas on how BP in acute stroke may influence stroke prognosis relate to the concept of the penumbra: because of cerebral vasoparalysis in the acute phase of stroke, blood flow in the ischemic penumbra is directly pressure dependent. ${ }^{42-45}$ One could postulate that, initially an elevated BP may serve to increase blood flow in the ischemic penumbra, thereby compensating for the impaired cerebral perfusion pressure. ${ }^{47268}$ However, a sustained high BP could be harmful, since it could lead to cerebral edema formation or trigger hemorrhagic transformation of the infarct. ${ }^{436}$ On the other hand, a low BP could lead to impaired perfusion with further anoxic cerebral damage as a result. ${ }^{414247.52}$ Studies that reported on the impact of BP in acute stroke and stroke outcome differed in their conclusions: some studies found no relationship between admission BP and outcome, ${ }^{46} 70-73$ others found high ${ }^{42} 485074-76$ or low ${ }^{77}$ BP values to be related with a poor outcome. Differences in study design probably explain some of these conflicting findings. Some studies included patients more than a week after the acute event, far beyond the period of any significant impact of BP on the penumbra. ${ }^{46} 7577$ Furthermore, studies differed in the way BP was recorded ${ }^{48} 75$ Only few studies investigated the prognostic value of 24-hour BP and its variation. ${ }^{485} 53$ Results of these studies are also conflicting. However, one could wonder if, apart from the early phase, these 24-hour BP values still have any impact on the salvage or destruction of cerebral tissue, as the penumbra turns into necrosis over time. ${ }^{145146}$

To investigate whether early 24-hour BP values and 24-hour BP variation are independent prognostic variables for stroke outcome, we studied 192 patients, admitted within 24 hours following stroke onset, with 24-hour BP monitoring. We evaluated whether there was a relationship between the outcome at six months following stroke and the first measured BP of the 24-hour registration, the day-and nighttime BP values, and the diurnal variation in BP. Furthermore, we studied the relationship between the fall of BP over the first 4 days and the outcome at six months.

\section{Patients and Methods}

\section{Data collection}

Between 1 January 1996 and 1 March 2000, data of patients with a stroke who were admitted to our hospital or visited the outpatient's clinic, were prospectively collected in an ongoing stroke registry at the University Hospital of Maastricht. The University Hospital is the only hospital in the Maastricht region and has an adherent population of approximately 200,000 people. Routine investigations included standard blood tests, electrocardiogram, chest X-ray, brain CT scan and carotid artery ultrasound studies. 
Echocardiography, 24-hour ECG monitoring and cerebral angiography were done in selected cases.

In this prospective study, 676 patients with a symptomatic ischemic stroke were admitted to our stroke unit within 24 hours following stroke onset. 516 patients of this group had a first brain infarct, whereas 160 patients had a recurrent infarct. In 271 of these 676 patients we prospectively collected 24-hour BP values. This 24-hour BP monitoring was started within the first 24 hours after stroke onset. We used an oscillometric HP M1205 Omnicare CMS monitor. The monitor was programmed to record at 30-minute intervals. In addition, the first BP measured after arrival on the first aid ward was noted. This BP was recorded manually by experienced nursing staff with a mercury sphygmomanometer (blood pressure values at 1st and 5th Korotkoff sounds taken as systolic and diastolic, respectively) (analysis is reported in chapter 4). In comparison with the total group of 676 patients, the studied group of 271 patients was relativeny' smal!: this was decause we dad' omy two BP' momitors at our disposal. T'o compare daytime with nighttime BP level, and to prevent any influence from BP changes during the transition hours, we took those $\mathrm{BP}$ measurements that were recorded between $9.00 \mathrm{~h}$ and $18.00 \mathrm{~h}$ as daytime BP values and BP measurements that were recorded between $24.00 \mathrm{~h}$ and $6.00 \mathrm{~h}$ as nighttime BP values. Furthermore, we only analysed those patients in whom over $80 \%$ data capture had been achieved, leaving 192 patients for our study. Finally, for each patient we collected a BP value that was taken at day four after stroke onset. On day 4, BP was taken only once during the daytime hours, by experienced nursing staff, with a mercury sphygmomanometer as described above.

As outcome measure we used the score on the Rankin handicap-scale at six months (see appendix). ${ }^{131}$ The score was dichotomized into a score $>3$ (poor outcome) versus a score $\leq 3$ (good outcome). ${ }^{134} 135$

\section{Blood pressure variables}

We explored the following variables:

- the first systolic (first SBP) and diastolic (first DBP) BP measured with the BP monitor.

- mean daytime systolic (daytime $S B P$ ) and diastolic (daytime DBP) $\mathrm{BP}$ as described above.

- mean nighttime systolic (nighttime SBP) and diastolic (nighttime DBP) BP as described above.

- absolute variation in diurnal systolic BP ( $a b s S B P$ ) and diastolic BP (abs DBP): the difference between the mean daytime systolic and mean nighttime systolic BP resp.the mean daytime diastolic and mean nighttime diastolic BP.

- percentage variation in diurnal systolic BP (perc SBP) and diastolic BP (perc DBP): the difference between the mean daytime systolic and mean nighttime systolic BP divided by the mean daytime systolic BP multiplied by $100 \%$ resp. the difference between the mean daytime diastolic and mean nighttime diastolic BP divided by the mean daytime diastolic BP multiplied by $100 \%$ 
- The fall in systolic (fall in $S B P$ ) resp. diastolic (fall in DBP) BP: the decline in BP between the systolic BP value measured after arrival on the first aid ward and the systolic BP value measured at day 4 resp. the decline in BP between the diastolic BP value measured after arrival on the first aid ward and the diastolic BP value measured at day 4 .

\section{Definitions}

Hypertension (HT) was defined as known hypertension (blood pressure recordings of more than $140 \mathrm{mmHg}$ systolic and/or $90 \mathrm{mmHg}$ diastolic pressure on at least two different occasions) whether or not treated with antihypertensive medication before the stroke. ${ }^{127}{ }^{128}$ Patients without known BP values, were considered hypertensive when treated with antihypertensive drugs.

Diabetes mellitus (DM) was defined as known diabetes treated with diet or medication, or either a fasting blood glucose higher than $7 \mathrm{mmol} / \mathrm{l}$ or a postprandial blood glucose higher than $11 \mathrm{mmol} / \mathrm{l}$, measured on at least two separate occasions before or at least one week after the stroke.

Ischemic heart disease (IHD) was defined as a history of angina pectoris, myocardial infarction or coronary bypass surgery.

A brain infarct was defined as the rapid onset of clinical signs of focal cerebral function disturbance, lasting longer than 24 hours or leading to death, with no apparent cause other than that of vascular origin with normal CT or CT showing an area of low attenuation compatible with the clinical signs and symptoms, or autopsy revealing an infarct compatible with the clinical signs and symptoms.

A lacunar infarct $(L A C I)$ was defined as an acute stroke syndrome with a CT lesion compatible with the occlusion of a single perforating artery, i.e., a small, subcortical, sharply marginated hypodense lesion with a diameter smaller than $15 \mathrm{~mm}$ (small deep infarct), or as a specific lacunar syndrome (i.e., unilateral motor and/or sensory symptoms and signs that completely involved at least 2 of 3 body parts (face, arm, and leg) without disturbance of consiousness or language, visual field defect, or other signs of cortical dysfunction) when the CT scan showed no specific lesion. A potential cardioembolic stroke cause was not taken into account when assigning patients to this infarct subgroup. A territorial infarct was defined as an acute stroke syndrome with CT findings compatible with infarction involving the cortex, or when no specific lesion was visible on CT, as a clinically identified cortical syndrome consisting of unilateral motor and/or sensory symptoms and signs in combination with signs of cortical dysfunction with or without visual field defect, or as isolated monoparesis or as isolated cortical dysfunction (usually dysphasia). Patients with a large subcortical infarct or a (non-lacunar) brainstem infarct were included in the territorial infarct group because of similar pathogenesis.

Territorial infarct patients with a potential cardioembolic stroke source were assigned to the cardioembolic stroke subgroup (CE). Such patients had at least one of the following cardiac features: chronic or intermittent ECG confirmed atrial fibrillation; left ventricular 
myocardial infarction within six weeks preceding stroke; left ventricular or atrial thrombus; left ventricular aneurysm; left ventricular akinetic segment; cardiomyopathy; mitral or aortic valve abnormalities (endocarditis, mitral stenosis, prosthetic aortic or mitral valves); and in young patients without any other specific stroke cause: atrial septal defect, ventricle septal defect. Patients with a non-cardioembolic symptomatic territorial infarct (presumably large vessel disease, i.e. atherothrombosis or artery-to-artery embolism whether or not confirmed by non-invasive carotid studies) were assigned to the atherothrombotic infarct subgroup (AT). Patients with a 'rare' stroke cause, such as arterial dissection, vasculitis, fibromuscular dysplasia, hematological disorder, etc. were not included in the study because of small numbers and heterogeneity in stroke cause.

An infarct was considered asymptomatic if located in an area that could not account for the neurological signs and symptoms, whereas the radiologically estimated age was not consistent with the time of clinical symptoms of the index stroke (old lesions being more hypodense, more sharply delineated, or showing signs of retraction of brain structures towards the lesion site on CT).

Leukoaraiosis (LA) on CT was defined as focal or diffuse hypodensities in the periventricular or deep white matter, not involving the cortex, and with ill-defined margins to distinguish them from infarction. ${ }^{139}$

Stroke severity on admission was scored using the Canadian Neurological Scale (CNS) (see appendix). ${ }^{140}$

\section{Statistical analysis}

To analyse the relationship between the various BP variables and the outcome at six months we used a logistic regression model containing various combinations of the following independent variables: stroke type (as described above), CNS (as described above) or Rankin score at admission (Rankin 3, 4 or 5 vs 1 and 2), age (similar as above), $\mathrm{IHD}$, gender, DM, hypertension before stroke and the various BP values as independent variables.

As dependent outcome variable we used the Rankin handicap score at six months, dichotomized in a score $>3$ vs a score $\leq 3$.

To determine the cut-off points for the different BP values we used the following method:

1. The Rankin score at six months was dichotomized as mentioned above.

2. The patients were sorted in ascending order by their blood pressure.

3. For patients with the same BP, the mean of the dichotomized Rankin score was calculated; this new mean Rankin value was subsequently assigned to all patients with this same BP.

4. The moving averages of the new mean Rankin scores were calculated, using a group size of 101 patients. ${ }^{136}$

5. As the calculated average could be interpreted as an estimate of the probability of an outcome with a Rankin score $>3$, the Odds of this average was calculated by dividing the average by one minus the average. 
6. The logOdds was plotted against the value of the blood pressure of the 51st patient of the concerning average.

Based upon these plots, the BP data were divided into three parts with cut-off points at $10 \mathrm{mmHg}$ below and $10 \mathrm{mmHg}$ above the BP-value that went together with the lowest logOdds. The BP data were put into the multivariate logistic regression model. By changing the cut-off points by adding or subtracting $5 \mathrm{mmHg}$, we explored which cut-off points showed the most significant relationship with outcome.

\section{Results}

In 271 patients, BP values were registered prospectively with use of an automatic monitoring device. In 192 patients over $80 \%$ data capture had been achieved. Table 1 shows the characteristics of the study group (192 patients) and the non-included patients $(676-192=484$ patients).

Table 1: Patient characteristics for the studied group $(N=192)$ and the remaining patients $(N=484)$ (for abbreviations see text)

\begin{tabular}{|c|c|c|}
\hline & $\begin{array}{l}\text { Studied group } \\
\mathrm{N},(\%)\end{array}$ & $\begin{array}{l}\text { Remaining patients } \\
\mathrm{N},(\%)\end{array}$ \\
\hline Sex: male & $108(56)$ & $238(49)$ \\
\hline female & $84(44)$ & $246(51)$ \\
\hline Age: median (range) & $74(35-91)$ & 74 (18-98) \\
\hline IHD & $61(32)$ & $155(32)$ \\
\hline DM & $30(16)$ & $89(18)$ \\
\hline HT & $96(50)$ & $228(47)$ \\
\hline Stroketype: LACI & $45(23)$ & $128(26)$ \\
\hline CE & 37 (19) & $108(22)$ \\
\hline AT & $110(57)$ & $248(51)$ \\
\hline \multicolumn{3}{|l|}{ CNS at admission: } \\
\hline$\leq 2$ & $16(8)$ & $46(9)$ \\
\hline$>2$ and $\leq 4$ & $24(13)$ & $72(15)$ \\
\hline$>4$ and $\leq 6$ & $32(16)$ & $70(15)$ \\
\hline$>6$ and $\leq 8$ & $61(32)$ & $137(28)$ \\
\hline$>8$ and $\leq 10$ & $59(31)$ & $159(33)$ \\
\hline
\end{tabular}

The study group contained slightly more males (56 vs $49 \%$ ). The remaining characteristics were distributed rather similar between the groups. 
Figure 1 shows the moving average relationship between the first systolic $\mathrm{BP}$ and the $\log$ Odds (Rankin $>3$ vs $\leq 3$ ). According to the plot, a BP value of $143 \mathrm{mmHg}$ shows the best relationship with a good outcome (Rankin $\leq 3$ at six months). When testing this relationship in the multivariate logistic regression analysis, we used as cut-off points 135 and $155 \mathrm{mmHg}$. This analyis showed no significant relationship between these BP-values and the outcome. Also, shifting the cut-off points as described earlier, no significant relationship was found with the outcome.

Fig.1: The logOdds of the moving average of the dichotomized

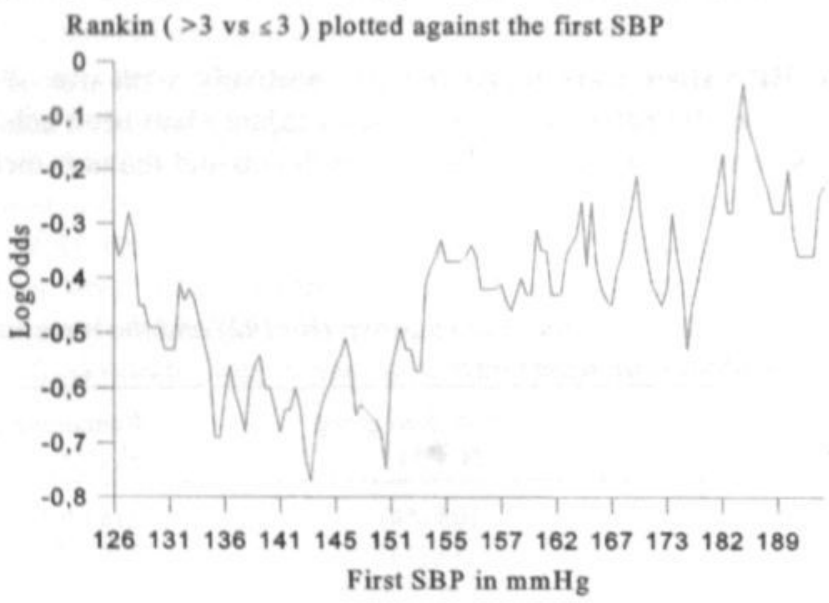

According to their specific plots, we analysed the relationship between the first diastolic $\mathrm{BP}$, the daytime systolic and diastolic BP and nighttime systolic and diastolic BP and the outcome in a similar way. The results are shown in table 2 . A first DBP $\leq 70 \mathrm{mmHg}$ was significantly related with a poor outcome, when the Rankin score at day 0 was put into the logistic regression model; when this Rankin score was replaced by the CNS scale at admission, the relationship with the outcome was not statistically significant anymore. 
Table 2: Relationship between several BP variables and outcome at six months: Rankin $>3$ vs $\leq 3$.

\begin{tabular}{|c|c|c|c|c|}
\hline \multicolumn{2}{|c|}{ BP-values $(\mathrm{mmHg})$} & \multirow{2}{*}{$\frac{\text { OR }}{2.3}$} & \multirow{2}{*}{$\frac{95 \% \mathrm{Cl}}{0.8-6.8}$} & \multirow{2}{*}{$\begin{array}{c}\text { P-value } \\
\text { ns }\end{array}$} \\
\hline First SBP & s $135(\mathrm{~N}=47)$ vs $136-154(\mathrm{~N}=43)$ & & & \\
\hline & $\geq 155(\mathrm{~N}=102)$ vs $136-154$ & 1.4 & $0.6-3.6$ & ns \\
\hline \multirow[t]{2}{*}{ First DBP } & $\leq 70(\mathrm{~N}=64)$ vs $71-99(\mathrm{~N}=110)$ & 2.3 & $1.0-5.5$ & 0.047 \\
\hline & 2 $100(\mathrm{~N}=18)$ vs $71-99$ & 0.5 & $0.1-1.7$ & ns \\
\hline \multirow[t]{2}{*}{ Daytime SBP } & $\leq 120(\mathrm{~N}=25)$ vs $121-139(\mathrm{~N}=52)$ & 0.8 & $0.3-1.8$ & ns \\
\hline & $\geq 140(\mathrm{~N}=115)$ vs $121-139$ & 1.7 & $0.5-5.9$ & ns \\
\hline \multirow[t]{2}{*}{ Daytime DBP } & $\leq 65(\mathrm{~N}=52)$ vs $66-84(\mathrm{~N}=108)$ & 0.5 & $0.2-1.3$ & ns \\
\hline & $285(\mathrm{~N}=32)$ vs $66-84$ & 0.9 & $0.3-2.8$ & ns \\
\hline \multirow[t]{2}{*}{ Nighttime SBP } & $\leq 115(\mathrm{~N}=30)$ vs $116-134(\mathrm{~N}=46)$ & 0.6 & $0.2-1.6$ & ns \\
\hline & $\geq 135(\mathrm{~N}=115)$ vs $116-134$ & 0.9 & $0.3-2.6$ & ns \\
\hline \multirow[t]{2}{*}{ Nighttime DBP } & $\leq 55(\mathrm{~N}=31)$ vs $56-74(\mathrm{~N}=106)$ & 1.9 & $0.8-4.3$ & ns \\
\hline & $\geq 75(\mathrm{~N}=55)$ vs $56-74$ & 1.3 & $0.4-4.3$ & ns \\
\hline
\end{tabular}

Figure 2 shows the moving average relationship between the fall in systolic BP and the logOdds (Rankin $>$ vs $\leq 3$ ).

The curve of this plot shows no apparent relationship between the fall in BP and outcome. When testing this relationship in the multivariate logistic regression analysis, we could not find a statistically significant relationship between the fall in systolic BP and the outcome at six months either. A similar analysis for the fall in diastolic BP also showed no significant association between the fall in DBP and the outcome at six months.

Fig.2: The logOdds of the moving average of the dichotomized Rankin ( $>3$ vs $\leq 3)$ plotted against the fall in SBP

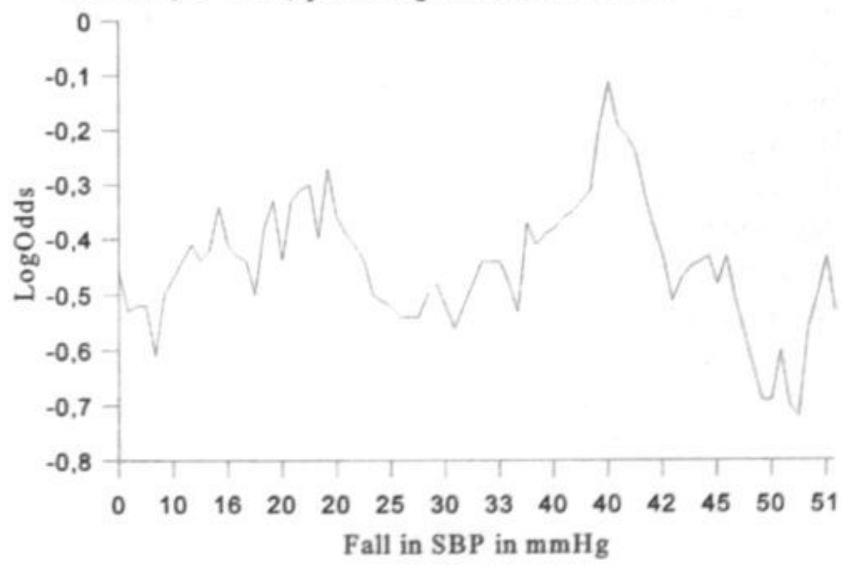


Figure 3 shows the moving average relationship between the absolute diurnal variation in systolic BP and the logOdds (Rankin $>3$ vs $\leq 3$ ). Testing this relationship in the multivariate logistic regression analysis, the absolute diurnal variation in systolic BP was not significantly related to outcome. Tested in a similar way, the absolute diurnal variation in diastolic BP and the percentage diurnal variation in systolic and diastolic BP also showed no significant relationship with outcome at six months following stroke onset.

Fig. 3: The logOdds of the moving average of the dichotomized

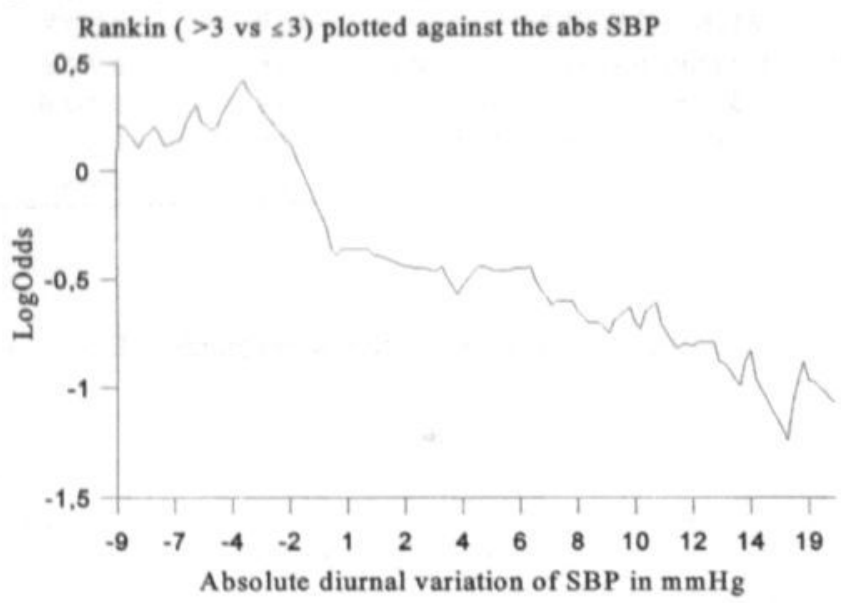

\section{Discussion}

We studied 24-hour BP values in patients who were admitted within 24 hours after stroke onset. Univariate analyses of the first measured BP value of the 24-hour registration showed a tendency for high and low BP values to be related to poor functional outcome at six months. However, after adjusting for other prognostic variables, we only found low first diastolic BP values to be significantly associated with poor outcome. When analysing mean 24-hour day- and nighttime BP values, we did not find a relationship between these $\mathrm{BP}$ values and outcome. We also found no relationship between BP variation or the fall in BP during the first four days, and functional outcome.

The relationship between BP in the acute phase of stroke and functional outcome has been studied by several other investigators. Some found no relationship between BP and outcome, ${ }^{46-73}$ whereas others found high ${ }^{42485074-76}$ or low ${ }^{77}$ BP values to be related with poor outcome. These conflicting data may be the result of differences in study design: some studies only included patients with cerebral hemorrhage ${ }^{50}$ while others mixed hemorrhages with infarcts ${ }^{48}$ or even TIA's. ${ }^{46}$ Some included patients more than a week 
after the acute event, ${ }^{46} 7577$ which is likely beyond the period of any impact of BP level on tissue salvage or further destruction. Conflicting data also exist on the prognostic significance of BP variation in ischemic stroke. Some studies found that decreased diurnal BP variation resulted in worse stroke outcome, ${ }^{48}$ whereas others found increased diurnal variation to be related to poor outcome. ${ }^{53}$ Some investigators stated that a significant fall in BP level within the first days was associated with poor outcome," whereas others found the opposite. ${ }^{64}$

We studied patients who were admitted within 24 hours after stroke onset. Since the exact time window of the existence of the penumbra is unknown, ${ }^{145}$ we not only studied the prognostic value of several 24-hour BP characteristics, but also the first measured BP value of the 24-hour BP monitoring. The fact that we found no relationship between several BP characteristics of the 24-hour registration and the outcome at six months, could mean that the period during which BP was being monitored surpassed the time of an amenable penumbra. On the other hand, when we restricted the analyses to BP measurements taken within 3 hours following stroke onset, we also found no statistically significant relationship with outcome ( see chapter 4).

A limitation of this study might be that not all eligible patients could be included in the study. However, we found no significant differences between the patients included and those who were not. Consequently, there is little reason to suspect that we have introduced major selection bias. Although from a pathophysiological perspective both

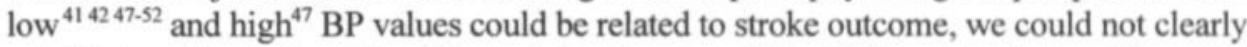
establish such relationships. The point estimates of the Odds ratios derived from the multivariate analyses nevertheless, suggested some relationship between BP extremes and outcome. It is possible that our study population was too small to detect significant relationships. However, any effect of BP extremes on stroke outcome would then likely be rather small. Thus, it is more likely that in the vast majority of ischemic stroke patients, BP values are in a range that does not jeopardize penumbral tissue. Similar reasoning may apply with respect to stroke trials aiming at early BP manipulation. Our data do not offer a hopeful perspective for early BP manipulation as a means to improve stroke outcome. Therefore, efforts to improve prognosis following stroke may better be directed towards alternative goals. 
7

The insula has not a unique role in blood pressure control 


\begin{abstract}
Background

The exact cause of blood pressure (BP) elevation in acute stroke remains unknown. Some investigators suggested a specific role of especially the right-sided insular cortex in the $\mathrm{BP}$ response in acute stroke, whereas others did not. Therefore, we investigated a possible independent relationship between infarct size and site, and the level of BP and circadian BP variation in the first 24 hours following acute ischemic stroke, with special reference to the insular cortex.
\end{abstract}

\title{
Methods
}

We collected BP values prospectively, including 24-hour BP registrations with an automatic monitoring device, in 271 acute ischemic stroke patients. We used the following BP variables: the first systolic and diastolic BP measured after arrival at the first aid ward, and the absolute and percentage diurnal variation in systolic and diastolic BP. We determined infarct size and site, by using T2-weighted and flair MRI images, that were performed within two weeks after stroke onset.

\section{Results}

The number of patients with elevated first BP was significantly higher in patients with a lacunar stroke compared to patients with a cortical stroke. We could not establish a relationship between early BP elevation and insular cortex involvement, cortical infarct size, or hemispheric side. We also found no relationship between insular involvement and diurnal BP variation.

\section{Conclusion}

Our findings indicate that the insular region has no specific role in autonomic function control, at least not as far as early BP rise and decrease of diurnal BP variation in acute stroke is concerned. Damage anywhere along the cerebral neuronal circuitry that regulates BP may elicit these phenomena. 


\section{Introduction}

Blood pressure (BP) is often elevated in the acute phase of stroke. ${ }^{53-58}$ The exact cause of this elevation remains unknown, but several pathophysiological mechanisms may be involved. One of the theories is that injury to the central autonomic nervous system results in pathological increased sympathetic activity. ${ }^{619196} 109$ Some investigators found a relationship between lesion site or size and BP level. Britton et al. stated that large lesions constituted a stimulus for reactive BP elevation. ${ }^{75}$ Sander et al. found that patients with insular infarcts, especially right-sided infarcts, exhibited diminished diurnal BP variation. They found a positive correlation between the extent of insular damage and plasma norepinephrine concentration. ${ }^{9196}$ Other studies, however, also found early BP increase and diminished diurnal BP variation in subcortical infarcts, or brainstem infarcts, challenging the idea of a single site control of autonomic function. ${ }^{889093}$ Studies that correlated specific infarct site with BP rise, or decrease in circadian BP variation were small, and did not account for other potentially related variables. For this reason, we investigated a possible independent relationship between infarct size and site, and the level of BP and circadian BP variation in the first 24 hours following acute stroke. Our main hypothesis was that right-sided insular damage is independently associated with early BP elevation and diminished diurnal BP variation in acute ischemic stroke. To be as accurate as possible in lesion localization, we restricted the study to patients who had undergone MRI.

\section{Patients and Methods}

\section{Data collection}

Between 1 January 1996 and 1 March 2000, data of patients with a stroke who were admitted to our hospital or visited the outpatient's clinic, were prospectively collected in an ongoing stroke registry at the University Hospital of Maastricht. The University Hospital is the only hospital in the Maastricht region and has an adherent population of approximately 200,000 people. Routine investigations included standard blood tests, electrocardiogram, chest X-ray, brain CT scan and carotid artery ultrasound studies. Echocardiography, 24-hour ECG monitoring and cerebral angiography were done in selected cases.

In this prospective study, 676 patients with ischemic stroke were admitted to our stroke unit within 24 hours following stroke onset. In 271 of these 676 patients we collected 24-hour BP values prospectively. First, we collected the first BP measured after arrival on the first aid ward: this BP was recorded manually by experienced nursing staff with a mercury sphygmomanometer ( blood pressure values at 1st and 5th Korotkoff sounds taken as systolic and diastolic respectively). Furthermore, we collected 24-hour BP values: this 24-hour BP monitoring was started within the first 24 hours following stroke onset and was performed using an oscillometric HP M1205 Omnicare CMS 
monitor. The monitor was programmed to record at 30-minute intervals. In comparison with the total group of 676 patients, the studied group of 271 patients was relatively small: this was because we had only two BP monitors at our disposal. To compare daytime with nighttime BP level, and to prevent any difference from blunting by intermediate BP values during BP transition hours, we took those BP measurements that were recorded between $9.00 \mathrm{~h}$ and $18.00 \mathrm{~h}$ as daytime BP values and BP measurements that were recorded between $24.00 \mathrm{~h}$ and $6.00 \mathrm{~h}$ as nighttime BP values. Furthermore, we only used those patients in whom over $80 \%$ data capture had been achieved, leaving 192 patients for our study. A brain MRI scan could be performed in 106 patients.

\section{Blood pressure variables}

We used the following variables:

- the first systolic and diastolic BP measured after arrival at the first aid ward.

- absolute variation in diurnal systolic and diastolic BP: the difference between the mean daytime systolic and mean nighttime systolic BP resp. the mean daytime diastolic and mean nighttime diastolic BP.

\section{Definitions}

Hypertension (HT) was defined as known hypertension (blood pressure recordings of more than $140 \mathrm{mmHg}$ systolic and/or $90 \mathrm{mmHg}$ diastolic pressure on at least two different occasions) whether or not treated with antihypertensive medication before the stroke. ${ }^{127}{ }^{128}$ Patients without known BP values, were considered hypertensive when treated with antihypertensive drugs.

Diabetes mellitus (DM) was defined as known diabetes treated with diet or medication, or either a fasting blood glucose higher than $7 \mathrm{mmol} / \mathrm{l}$ or a postprandial blood glucose higher than $11 \mathrm{mmol} /$, measured on at least two separate occasions before or at least one week after the stroke.

Ischemic heart disease (IHD) was defined as a history of angina pectoris, myocardial infarction or coronary bypass surgery.

A brain infarct was defined as the rapid onset of clinical signs of focal cerebral function disturbance, lasting longer than 24 hours or leading to death, with no apparent cause other than that of vascular origin, with normal CT or CT showing an area of low attenuation, or with a hyperintens lesion on T2-weighted or flair MRI image, compatible with the clinical signs and symptoms.

A lacunar infarct $(\mathrm{LACl})$ was defined as an acute stroke syndrome with a CT or MRI lesion compatible with occlusion of a single perforating artery, i.e., a small, subcortical, sharply marginated hypodense/hypertintens lesion with a diameter smaller than $15 \mathrm{~mm}$ (small deep infarct), or as a specific lacunar syndrome (i.e., unilateral motor and/or sensory symptoms and signs that completely involved at least 2 of 3 body parts (face, 
arm, leg), without disturbance of consiousness or language, visual field defect, or other signs of cortical dysfunction) in the absence of a specific lesion on neuro-imaging. A potential cardioembolic stroke cause was not taken into account when assigning patients to this infarct subgroup.

A territorial infarct was defined as an acute stroke syndrome with CT or MRI findings compatible with an infarct involving the cortex, or in the absence of a specific lesion, as a clinically identified cortical syndrome consisting of unilateral motor and/or sensory symptoms and signs in combination with signs of cortical dysfunction with or without visual field defect, as isolated monoparesis, or as isolated cortical dysfunction (usually dysphasia). Patients with a large subcortical infarct or a (non-lacunar) brainstem infaret were included in the territorial infarct group because of similar pathogenesis.

Territorial infarct patients with a potential cardioembolic stroke source were assigned to the cardioembolic stroke subgroup (CE). Such patients had at least one of the following cardiac features: chronic or intermittent ECG confirmed atrial fibrillation; left ventricular myocardial infarction within six weeks preceding stroke; left ventricular or atrial thrombus; left ventricular aneurysm; left ventricular akinetic segment; cardiomyopathy; mitral or aortic valve abnormalities (endocarditis, mitral stenosis, prosthetic aortic or mitral valves); and in young patients without any other specific stroke cause: atrial septal defect, ventricle septal defect. Patients with a non-cardioembolic symptomatic territorial infarct (presumably large vessel disease, i.e. atherothrombosis or artery-to-artery embolism whether or not confirmed by non-invasive carotid studies) were assigned to the atherothrombotic infarct subgroup (AT). Patients with a 'rare' stroke cause, such as arterial dissection, vasculitis, fibromuscular dysplasia, hematological disorder, etc. were not included in the study because of small numbers and heterogeneity in stroke cause.

An infarct was considered asymptomatic if located in an area that could not account for the neurological signs and symptoms, whereas the radiologically estimated age was not consistent with the time of clinical symptoms of the index stroke (old lesions being more hypodense on CT, more sharply delineated, or showing signs of retraction of brain structures towards the lesion site on CT or MRI).

With regard to infarct size, we distinguished between large territorial infarcts that involved the entire area supplied by the anterior or posterior cerebral artery (ACA or PCA), or the complete or larger part of the middle cerebral artery (MCA), and territorial infarcts that were smaller, involving only a medium size branch or a small branch area. In addition, the affected gyri of all territorial lesions (both the symptomatic and silent or old lesions) were identified according to Bories' method allowing a detailed topographical description of cortically affected areas in different gyri. ${ }^{147}$ Three groups of gyri were distinguished that largely comply with the areas compatible with the anterior, posterior and middle cerebral artery supply areas. The site and location of the infarcts was scored using the T2-weighted and flair MRI images.

Stroke severity on admission was scored using the Canadian Neurological Scale (CNS) (see appendix). ${ }^{140}$

Elevated $B P$ after stroke onset was defined as a systolic $\mathrm{BP}$ value $>140 \mathrm{mmHg}$, and/or a diastolic BP value $>90 \mathrm{mmHg}$, as measured directly after arrival on the first aid ward. ${ }^{127128}$ 


\section{Statistical analysis}

For analysis we used a logistic regression model containing the following independent variables: age ( $<70$ vs $>70$ years), sex, infarct size (large vs medium and small sized infarcts), infarct side, hypertension before stroke and involved gyrus (insular cortex or precentral gyrus or post-central gyrus or pre- and post-central gyrus together). As dependent variable we used the systolic ( $~>140 \mathrm{vs}<140 \mathrm{mmHg}$ ) and diastolic BP $(<90$ vs $<90 \mathrm{mmHg}$ ) at admission or the absolute diurnal systolic ( $22 \mathrm{vs}<2 \mathrm{mmHg}$ ) or diastolic BP ( $z 3,5 \mathrm{vs}<3,5 \mathrm{mmHg}$ ) variation (the cut-off points for the absolute diurnal systolic and diastolic BP variation were established by dividing the diurnal BP variation in two equal parts).

\section{Results}

The characteristics of the patients included in the study $(\mathrm{N}=106)$ and the patients who were not $(\mathrm{N}=676-106=570)$ are shown in table 1 . Patients in the study group had a slightly better CNS score at admission than the remaining patients. Furthermore, there were fewer patients with known diabetes mellitus before stroke onset in the study group (table 1). The remaining characteristics were rather similar between the groups. Patients in whom MRI was not performed were probably those with more severe deficit.

Table 1: Patient characteristics of the study group $(N=106)$ and the remaining patients $(N=570)$ (for abbreviations see text)

\begin{tabular}{|c|c|c|}
\hline & $\begin{array}{l}\text { Study group } \\
\mathrm{N},(\%)\end{array}$ & $\begin{array}{l}\text { Remaining patients } \\
\mathrm{N},(\%)\end{array}$ \\
\hline Sex: male & $55(52)$ & $292(51)$ \\
\hline female & $51(48)$ & 279 (49) \\
\hline Age: median (range) & $70(35-87)$ & 74 (18-98) \\
\hline IHD & $31(29)$ & $182(32)$ \\
\hline DM & $13(12)$ & $106(18)$ \\
\hline HT & $49(46)$ & $275(48)$ \\
\hline Stroketype: LACI & $25(23)$ & $146(26)$ \\
\hline $\mathrm{CE}$ & $23(22)$ & $122(21)$ \\
\hline AT & $58(55)$ & $302(53)$ \\
\hline \multicolumn{3}{|l|}{ CNS at admission: } \\
\hline$\leq 2$ & $5(5)$ & $57(10)$ \\
\hline$>2$ and $s 4$ & $8(7)$ & $87(15)$ \\
\hline$>4$ and $\leq 6$ & $19(18)$ & $83(15)$ \\
\hline$>6$ and $s 8$ & $35(33)$ & $163(28)$ \\
\hline$>8$ and $\leq 10$ & 39 (37) & $180(32)$ \\
\hline
\end{tabular}


Relationship of the first measured BP at the first aid ward with site and size of the infarct.

Forty-nine of the 81 patients with a territorial stroketype had a symptomatic cortical infarct on MRI. Eighteen of the 81 patients had a subcortical, non-lacunar infarct on MRI. Twelve had a (non-lacunar) brainstem infaret on MRI; these were not further analysed. The remaining two of the 81 patients did not show an infarct on the MRI. Twenty-two of the 25 patients with a lacunar stroketype showed a symptomatic lacunar infarct on MRI, whereas the remaining 3 patients did not show such infarct on MRI (table 2).

Table 2: Proportion of patients with elevated first $B P$ values $(B P t)$, related to infarct type, hemispheric $(H)$ side, or insular cortex involvement.

\begin{tabular}{llll}
\hline & All & Right H & Left H \\
& $\mathrm{N}, \mathrm{BP}^{\dagger}(\%)$ & $\mathrm{N}, \mathrm{BP} \mathrm{PP}^{\dagger}(\%)$ & $\mathrm{N}, \mathrm{BP}^{\dagger}(\%)$ \\
\hline Cortical infarct & $49,34(69)$ & $25,16(64)$ & $24,18(75)$ \\
INS + & $29,18(62)$ & $17,10(59)$ & $12,8(67)$ \\
INS - & $20,16(80)$ & $8,6(75)$ & $12,10(83)$ \\
LACI & $22,20(91)$ & $10,8(80)$ & $12,12(100)$ \\
Subcortical & $18,14(78)$ & $12,10(83)$ & $6,4(67)$ \\
\hline
\end{tabular}

Table 2 shows the proportion of patients with elevated first BP values, related to infarct type, whether the lesion was in the left or right hemisphere, and whether or not the insular cortex was involved. There were no statistically significant differences in the number of patients with elevated first BP, between patients with or without insular involvement, and between patients with a right- or left-sided insular infarct (independent-samples $\mathrm{T}$ test). The number of patients with elevated BP was significantly higher in the lacunar infarct group compared to the cortical infarct group (independent-samples $\mathrm{T}$ test).

Table 3 shows how often the various gyri were involved in the infarct, in the 49 cortical infarct patients with or without first BP elevation. Analysing any independent relationship between any particular cortical gyrus and BP elevation by means of logistic regression analysis, did not reveal any such relationship. Also, infarct size or hemispheric side were not related with the BP variables. 
Table 3 : Affected cortical gyri in 49 patients with a cortical infarct; distinction between 34 patients with elevated first measured $B P(B P I)$ and 15 without. Number of patients with particular gyrus damaged.

\begin{tabular}{|c|c|c|}
\hline Territorial gyri $(G)$ & $\begin{array}{l}\text { Patients with BP } t \\
(\mathrm{~N}=34) \\
\mathrm{N},(\%)\end{array}$ & $\begin{array}{l}\text { Patients without BP! } \\
(\mathrm{N}=15) \\
\mathrm{N},(\%)\end{array}$ \\
\hline \multicolumn{3}{|c|}{ Anterior cerebral artery territory: } \\
\hline - rectal G & 0 & 0 \\
\hline - superior frontal G & $2(6)$ & $\mathbf{0}$ \\
\hline - cingulate G & $2(6)$ & 0 \\
\hline - precuneus G & 0 & 0 \\
\hline - paracentral lobule & $1(3)$ & 0 \\
\hline \multicolumn{3}{|c|}{ Middle cerebral artery territory: } \\
\hline - orbital G & 0 & 0 \\
\hline - superior temporal G & $16(47)$ & $10(67)$ \\
\hline - middle temporal G & $14(41)$ & $8(53)$ \\
\hline - inferior temporal G & 0 & $1(7)$ \\
\hline - middle frontal G & $6(18)$ & $1(7)$ \\
\hline - inferior frontal G & $10(29)$ & $4(27)$ \\
\hline - precentral G & $14(41)$ & $10(67)$ \\
\hline - post-central G & $12(35)$ & $9(60)$ \\
\hline - supramarginal G & $11(32)$ & $7(47)$ \\
\hline - angular G & $7(20)$ & $3(20)$ \\
\hline - occipital lobe & 0 & $1(7)$ \\
\hline - superior parietal lobule & $1(3)$ & 0 \\
\hline - central sulcus & $1(3)$ & 0 \\
\hline - sylvian fissure & 0 & $1(7)$ \\
\hline - insular cortex & $18(53)$ & $11(73)$ \\
\hline \multicolumn{3}{|c|}{ Posterior cerebral artery territory: } \\
\hline - parahippocampal G & $2(6)$ & $2(13)$ \\
\hline - fusiform G & $2(6)$ & $2(13)$ \\
\hline - uncus & 0 & 0 \\
\hline - occipital lobe & $2(6)$ & $3(20)$ \\
\hline - cingulate G & $1(3)$ & $1(7)$ \\
\hline - lingual G & $2(6)$ & $1(7)$ \\
\hline - cuneus & $1(3)$ & 0 \\
\hline -precuneus & 0 & 0 \\
\hline - calcarine sulcus & 0 & 0 \\
\hline - parieto- occipital fissure & 0 & $1(7)$ \\
\hline
\end{tabular}


Relationship of diurnal BP variation with site and size of the infarct.

Of the 192 patients who had over $80 \%$ data capture of the 24-hour BP measurements, 73 had an MRI. Table 4 shows the characteristics of these 73 and the remaining 603 patients.

Table 4: Patient characteristics of the study group $(\mathrm{N}=73)$ and the remaining patients $(N=603)$ (for abbreviations see text)

\begin{tabular}{|c|c|c|}
\hline & $\begin{array}{l}\text { Study group } \\
\mathrm{N},(\%)\end{array}$ & $\begin{array}{l}\text { Remaining patients } \\
\mathrm{N},(\%)\end{array}$ \\
\hline Sex: male & $38(52)$ & $309(51)$ \\
\hline female & $35(48)$ & 294 (49) \\
\hline Age: median (range) & $72(35-87)$ & 74 (18-98) \\
\hline IHD & $21(29)$ & $196(32)$ \\
\hline DM & $8(11)$ & $111(18)$ \\
\hline HT & $32(44)$ & 293 (49) \\
\hline Stroketype: Laci & $16(22)$ & 157 (26) \\
\hline $\mathrm{CE}$ & $17(23)$ & $129(21)$ \\
\hline AT & $40(55)$ & $317(53)$ \\
\hline \multicolumn{3}{|l|}{ CNS at admission: } \\
\hline$\leq 2$ & $3(4)$ & $57(9)$ \\
\hline$>2$ and $\leq 4$ & $5(7)$ & $90(15)$ \\
\hline$>4$ and $\leq 6$ & $12(17)$ & $90(15)$ \\
\hline$>6$ and $\leq 8$ & $25(34)$ & 173 (29) \\
\hline$>8$ and $\leq 10$ & $28(38)$ & $193(32)$ \\
\hline
\end{tabular}

Thirty-four patients had a territorial infarct on the MRI scan. Fourteen of the 34 patients had an infarct in the left and 20 had an infarct in the right hemisphere. There was no statistically significant difference in absolute or percentage diurnal variation in systolic or diastolic BP between these two groups. Twenty-one of the 34 patients had an infarct involving the insular cortex, whereas 13 had not. There was no statistically significant difference in absolute or percentage diurnal variation in systolic or diastolic BP between these two groups. Analysing any independent relationship between the particular cortical gyrus and absolute diurnal BP variation by means of logistic regression analysis, showed that insular involvement was associated with higher diurnal diastolic BP variation (OR $17 ; 95 \% \mathrm{CI} 1.8-155.9$ ). Infarct size or hemispheric side were not related to the BP variables. 


\section{Discussion}

We analysed whether early BP elevation, and diurnal BP variation in patients with an acute cerebral infarct were related to infarct site or size, or the involvement of certain cortical gyri, the insular cortex in particular. We found no differences between patients with or without early BP elevation with regard to whether the lesion was in the right or left hemisphere, nor whether the insular cortex was involved or not. Furthermore, we could not establish a relationship between early BP elevation and insular cortex involvement, cortical infarct size, or hemispheric side in multivariate regression analysis. Opposite to what we expected, considering the findings of others, we found insular cortex involvement to be related to a higher, instead of lower, diurnal BP variation in multivariate regression analysis. However, we can not exclude this to be a finding by chance, as we have no biologically plausible explanation for this finding, and patient numbers were relatively small.

Our findings do not concur with a specific role attributed to the insular cortex in autonomic function control, at least, not as far as early BP rise and degree of diurnal BP variation in acute stroke is concerned. ${ }^{148-150}$ Cheung and Hachinski recently reviewed the role of the insula in cerebrogenic cardiovascular and autonomic disturbances. ${ }^{151}$ They pointed at experimental and clinical data sustaining the role of the insular area, the rightsided insula in particular, in the modulation of sympathetic activity. Damage to especially the right insula may result in sympathetic overactivity. Clinical evidence that favours the role of the insula in autonomic function control comes mainly from patients with cerebral infarction. Involvement of the insula in middle cerebral artery infarcts may provide an "experiment of nature" from which inferences may be made on regular functions of this area. However, most studies on variables of autonomic function in patients with stroke involving the insular region measured parameters of cardiac function, such as heart rate variability, ${ }^{152-156}$ arythmias, ${ }^{149} 157$ repolarisation characteristics, ${ }^{158}$ or cardio baroreceptor sensitivity. ${ }^{95}$ It seems logical to consider BP regulation and control of diurnal BP variation as variables of the autonomic nervous system function, and relate changes in these features to the area of damage in stroke to study the role of that area in autonomic function control. However, the number of such studies is limited, and were performed by only one group. Sander et al. found a correlation between the extent of insular infarct involvement on MRI and circadian BP variation in 52 patients with hemispheric infarction. ${ }^{109}$ However, there was also a relationship between infarct size and insular involvement, so that one can not exclude any influence of infarct size on the relationship. Besides, the number of patients with or without insular involvement were not provided.There was, however, a correlation between the extent of insular damage and norepinephrine levels, and also with QTc prolongation. The study does not allow a definite conclusion on the relationship between insular damage related sympathetic overactivity and diurnal BP variation decrease. In an earlier study, the same authors found no relationship between infarct size and insular involvement in 45 hemispheric infarct patients, of whom about 75 percent had MRI. ${ }^{92}$ They found a highly significant difference in the proportion with nocturnal BP decrease between 18 patients with and 17 
without insular involvement using univariate comparison. No multivariate testing was done, especially not with other brain regions as independent variables. Some patients were included in the study up to one week after stroke onset. How long after stroke BP measurements take place is of importance, as the decrease of diurnal variation is a transient phenomenon, whereas it is unknown how eventual return to normal diurnal BP pattern develops over time, nor what factors influence such normalisation. In a third study, of a consecutive series of 35 patients who were admitted within 48 hours after stroke onset, 20 had left-, and 15 had right-sided hemispheric infarction. ${ }^{91}$ Two-third of them had MRI. In nine of the left- and six of the right-sided infarcts the insular cortex was involved. Patients with right-sided infarction showed significant reduction in diurnal BP variation compared to left-sided infarets. Patients with insular damage showed significantly more often decreased diurnal BP variation than those without, but this difference was not restricted to right-sided infarcts. Although the groups showed no 'statistically significant difference' with regard to various patient characteristics, this does not make multivariate testing redundant.

So, these three studies were performed by the same authors, had similar study design, and although they were published very closely in time, any possible repeated participation of patients in different studies was not addressed. Why our results differ from those of Sander et al. is not clear. We did not exclude patients who received antihypertensive treatment or anti-arrythmic drugs, or any other lesion on MRI, as Sander et al. did. But it is unlikely that this difference would explain any absence of insular role in early BP rise or diurnal BP variation decrease, as both these phenomena were highly prevalent in our study. It could be, though, that the role of the insula was blunted by the role other lesions may play, such as 'silent' lacunar infarcts, for example. However, in chapter 5 we just found the opposite: such lesions were associated with less diurnal BP variation decrease. Lesion characterisation may not have been optimal in the studies of Sander et al., as in two of their studies not all patients had MRI, like in our study. However, this also is unlikely to explain the difference, as findings were rather consistent between their three separate studies. We included only patients within 24 hours after stroke onset. In the studies of Sander et al. it was 48 hours in two studies, whereas a maximal period was not mentioned in one study. The results of Sander et al. may allow the conclusion that the insular cortex plays a role in the recovery of physiological diurnal $\mathrm{BP}$ patterning following the acute stroke phase, rather than in raising early BP and abolishing diurnal BP variation in acute stroke. Another strong argument that the insular cortex is unlikely to play an unique role in these acute stroke phenomena, is that they also occur in infarcts not involving the cortex at all, such as lacunar and larger subcortical infarcts. In fact, these phenomena occurred even more often in these infarct groups than in infarcts involving the insular region. Subcortical lesions may also affect the integrity of the autonomous nervous system with, consequently, sympathetic overshoot. Therefore, our study does not deny a role of the insula in autonomic function disturbances following stroke, but its role is not unique. Lesions at different sites in the neuronal circuitry that sustain the autonomic nervous system balance may result in dysfunction. The findings of Yamamoto et al. sustain such idea. ${ }^{93}$ They found that the 
degree of nocturnal BP decline was related to various (ischemic) lesion sites. They found that patients with multiple lacunar lesions had the smallest diurnal BP variation decline. The sympathetic response on BP in acute stroke may become blunted by the presence of prior lesions, especially when these are multiple.

In conclusion: experimental and clinical data have revealed a crucial role of the insular cortex in the autonomic nervous system cardiovascular control. From our data, however, we can not infer an unique role of the insular region in sympathetic overactivity that induces early BP rise and decrease of diurnal BP variation in acute stroke. Damage anywhere along the cerebral neuronal circuitry involved in BP regulation, may elicit these phenomena. The response may be blunted when the integrity of the autonomic regulatory system is already damaged by prior lesions. 
8

General discussion 
This thesis encompasses a retrospective and a prospective part. We wanted to explore whether blood pressure (BP) in acute stroke is related to functional outcome, because it is important to find indications whether BP manipulation in acute stroke could perhaps improve prognosis. For that purpose we also needed to know more about the course of $\mathrm{BP}$ in the acute phase of stroke, and identify patients who have a higher risk in developing elevated BP levels after stroke onset.

In the retrospective part, we explored predictors of post-stroke BP level, and the course of the BP level in the first week after stroke onset. Furthermore, we studied the prognostic value of $\mathrm{BP}$ in acute stroke. We performed these studies in patients who were admitted to the stroke unit within 24 hours following stroke onset. First, we found that known hypertension before stroke was an independent predictor of initial BP level in acute stroke. Second, elevated BP in acute stroke decreased spontaneously during the first days after stroke, with the greatest decline during the first three days. BP level during the first week was higher in patients known with hypertension before stroke than in those without. Since different stroke subtypes have different underlying pathophysiological mechanisms, stroke subtype may influence BP level and course. However, we found no significant difference in initial BP level, nor in the course of BP between patients with different stroke subtypes. These findings indicate that cause, size, and location of the infarct are not related to the level and course of BP in acute stroke. Furthermore, we found no significant relationship between the first measured BP after admission and functional outcome. BP values measured during the daytime hours of the first 24 hours after stroke, also showed no relationship with outcome, whereas high and low nighttime $\mathrm{BP}$ values were related to poor outcome. Since a retrospective study could create bias towards an increased chance of detecting extreme BP values, the strength of an association between BP and outcome could be overestimated. Consequently, we decided to perform a prospective study in patients admitted within 24 hours after stroke onset.

In this prospective study, we found that patients known with hypertension before stroke or patients with asymptomatic lacunar infarcts on CT had significantly higher first $\mathrm{BP}$ values than those without the specific feature. Again, no relationship was found between stroke subtype and level of first BP. We found no relationship between the first measured BP values after admission at the first aid ward, and functional outcome. Results of other studies varied: some found no relationship between BP in the acute phase of stroke and functional outcome, ${ }^{4670-73}$ whereas other studies found high ${ }^{4248} 5074.76$ or low 77 $\mathrm{BP}$ values to be related to poor outcome. When studying the relationship between 24 -hour BP measurements and outcome, we only found low first (of the 24-hour BP measurements) measured diastolic BP values to be significantly related to poor functional outcome, whereas mean daytime and nighttime BP values were not. The period during which these last BP variables were being monitored, likely surpassed the time of an amendable penumbra. Since cerebral autoregulation is disturbed after stroke onset, cerebral perfusion is directly dependend on systemic BP..$^{42-45}$ In this perspective, low or high BP values, or both, would be expected to relate to stroke outcome. We could not clearly establish such relationship, possibly because our study population was too small, and any relationship went undetected. However, any effect of BP extremes on stroke 
outcome would than likely be rather small. Maybe, studying only predefined subgroups with high or low BP values in acute stroke, could show the expected relationship with outcome, but even then, large numbers would be required. If so, it would make an intervention trial in acute stroke not easy, whereas, if any benefit would be proven, it would only be applicable in small patient groups: those with extremely high or low BP level. Therefore, on the basis of our data, the possibility of an integral BP treatment for all stroke patients does not seem to be a feasible option to be studied in a clinical trial.

It is well known that there is a diurnal pattern of BP change, with morning values higher than those recorded in the evening, and a further decrease (dip) during nighttime. ${ }^{78-82}$ Other investigators found that stroke patients show a decrease in diurnal variation. ${ }^{59} 8186$ ${ }^{90} 92$ This was in line with our findings. We found no relationship between diurnal BP variation, as registered with 24-hour BP monitoring, and outcome. Patients with lacunar stroke, especially those known with hypertension, had the largest diurnal BP variation. We also found that patients with asymptomatic lacunar infarcts on CT had higher diurnal $\mathrm{BP}$ variation than patients without. So, why does a subgroup of stroke patients with rather extreme forms of hypertensive end-organ damage in the brain, have the largest diurnal BP variation in acute stroke? One reason could be that this damage is not directly caused by the hypertension: the two phenomena are related, but not (completely) causally. This hypothesis is strengthened by our earlier findings that asymptomatic infarcts and leukoaraiosis progress over time, despite measures of secondary stroke prevention, among which, treatment of hypertension. ${ }^{141}$ Therefore, hypertension treatment in patients with large variation in diurnal BP values, such as so-called 'dippers', may lower BP values under the limit where sufficient cerebral perfusion pressure can be maintained, which could lead to ischemic lesions. So, there may be a stroke subgroup in which hypertension treatment does not prevent, but rather enhances further end-organ damage. This specific group of patients, with small vessel arteriolosclerosis, is small in stroke series, and may comprise approximately five percent of all ischemic stroke patients. They were never considered separately in trials on the effect of hypertension treatment in lowering vascular end-points such as stroke, nor have they been considered separately in end-point measurements. Another possibility to explain the finding of a large diurnal BP variation in our lacunar stroke patients could be that these patients have a more physiological sleeping pattern than patients with more extended cerebral damage.

Finally we studied whether early BP elevation, and diurnal BP variation in patients with an acute cerebral infarct were related to infarct site or size, or the involvement of certain cortical gyri, the insular cortex in particular. We found no differences between patients with or without early BP elevation with regard to whether the lesion was in the right or left hemisphere, nor whether the insular cortex was involved or not. When we considered cortical and subcortical infarcts separately, there were also no differences. Furthermore, we could not establish a relationship between early BP elevation and insular cortex involvement, cortical infarct size, or hemispheric side. Also, we found no relationship between insular involvement and diurnal BP variation. Our findings indicate that the 
insular region has no specific role in autonomic function control, at least not as far as early BP rise and decrease of diurnal BP variation in acute stroke is concerned. Damage anywhere along the cerebral neuronal circuitry that regulates BP may elicit these phenomena. The integrity of a regulatory system may therefore be more important than that of a particular component of the system. However, what factors are involved in the normalisation of BP level, and diurnal BP variation during the first weeks following stroke, is unknown. Damage to the insular cortex may slow down this normalisation. Continuous BP measurements for one or two weeks following stroke, may test this hypothesis. 
9

Summary 
Stroke is an important disease. In the Netherlands there are approximately 30.000 new strokes each year. Until today, thrombolysis is the only available effective therapy for ischemic stroke patients. However, only five to ten percent of all ischemic stroke patients will be eligible for this therapy. An additional possibility to improve prognosis following stroke may be achieved by manipulating the level of blood pressure (BP) in acute stroke. What BP values should be treated, and what BP level to aim at in such treatment remains enigmatic. In addition, it's dangerous to treat BP in a uniform manner. This consideration relates to the concept of cerebral autoregulation, which implies that under normal conditions regional cerebral blood flow is kept constant over a certain range of systemic BP. In stroke, this mechanism is lost, and cerebral perfusion becomes directly BP dependent. High BP levels may thereby result in edema formation and local hemorrhage, which leads to further damage. Low systemic BP, on the other hand, can not be compensated for, and will also lead to further ischemic damage. So far, little is clear about what factors independently predict the level of BP in the acute phase of stroke, or what BP characteristics are independent predictors of stroke outcome. Before any clinical trial on BP treatment in acute stroke can be rationalized, more data on these issues are required. In the present study we explored and investigated factors related to BP level and course in acute stroke, and various BP characteristics as independent predictors of stroke outcome.

In chapter 1 the relevant literature on this subject is reviewed: BP is elevated in 70 to 94 percent of acute stroke patients. This elevated BP spontaneously declines during the first week. Data on the prognostic significance of BP levels following acute stroke are conflicting: some studies showed no relationship between admission BP and outcome, whereas others reported high or low admission BP to be related to poor outcome.

In normotensive persons, there is a diurnal pattern of BP change with morning values being higher than those recorded in the evening, and with further decrease during nighttime. An arbitrarily chosen absolute $10 \mathrm{mmHg}$ day minus night $\mathrm{BP}$ fall, or a 10 percent BP decrease is called 'dipping'. Stroke patients show a decrease in diurnal BP variation. Data on the prognostic significance of the degree of diurnal BP variation after stroke are controversial.

In chapter 2 BP values of 409 patients with a first-ever ischemic stroke, admitted within 24 hours after stroke onset were studied. BP values that were measured within these first 24 hours were collected in retrospect. Linear regression analyses showed that the level of first BP measured after admission at the stroke unit was significantly related with age, known ischemic heart disease and known hypertension before stroke onset. Stroke type (atherothrombotic, lacunar or cardioembolic) and Rankin score at stroke onset were not significantly associated with initial BP level. Besides the first BP measured after admission, we studied several characteristics of the mean daytime BP value (measured between 9.00 and 18.00 hours) and mean nighttime BP value (measured between 24.00 and 6.00 hours). The course of BP level was studied during the first week after stroke onset. BP fell during this first week with the greatest decline during the first 3 days. 
Nighttime BP showed a similar course as daytime BP. Patients in a control group showed a similar course. BP during the first week was higher in patients with hypertension before stroke than in those without known hypertension. There was no significant difference in initial BP level nor in the course of BP when comparing atherotrombotic with cardioembolic or lacunar stroke patients.

We concluded that an increase in post-stroke BP is not a general phenomenon, nor is the decline in BP in the first week post-stroke. Both phenomena occur irrespective of stroke subtype. Known hypertension is probably the strongest predictor of post-stroke BP increase.

In chapter 3 we studied the prognostic value of BP in acute stroke. For this study we used the same patient group as in chapter 2 . As outcome variable we used the Rankin score at three months: a Rankin score $\leq 3$ was used as good outcome, a Rankin score $>3$ as poor outcome. Univariate analysis suggested that both low and high BP values were related to poor outcome. Multivariate analyses showed no significant relationship between the first measured BP after admission and functional outcome at three months. Multivariate analysis also showed no relationship between daytime BP values and outcome at three months, whereas a significant association was found between nighttime $\mathrm{BP}$ and outcome: a nighttime systolic BP $\geq 165 \mathrm{mmHg}$ or a nighttime diastolic BP $\leq 60 \mathrm{mmHg}$ was significantly related with poor outcome (OR 2.8; $95 \%$ CI 1.1-6.8 resp. OR 8.1; $95 \%$ CI 1.1-58.3). When studying the relationship between the fall in BP and outcome, we found a decrease in daytime diastolic BP during the first 4 days after stroke onset $\geq 10 \mathrm{mmHg}$ to be associated with poor outcome (OR $3.0 ; 95 \%$ CI 1.1-7.9).

We concluded that unadjusted BP values towards the lower and higher end were related with poor outcome, but warned against unadjusted analysis of first post-stroke BP as outcome predictor. Nighttime BP values may have independent predictive value for stroke outcome. The data suggest that lowering very high BP may be beneficial, provided it is not lowered too drastically, while conversely increasing a low BP may confer benefit as well. This retrospective study, may however overestimate the strength of association between BP and outcome, as it could be biased towards inclusion of more patients with sustained high or low BP values.

In chapter 4 we studied the prognostic value of the first BP measured after admission at the first aid ward in 271 patients with an ischemic stroke. This was a prospective study; patients were included within 24 hours following stroke onset. As dependent outcome variable, we used the score on the Rankin handicap-scale at six months (Rankin $>3$ as poor outcome versus Rankin $\leq 3$ as good outcome). We found that patients with known hypertension before stroke onset had a significantly higher first systolic BP than those without. Furthermore, males had a significantly higher first systolic and diastolic BP than females. With increasing age, the systolic first BP value rose significantly. Patients with asymptomatic lacunar infarcts on CT had significant higher first systolic and diastolic BP values than those without. Finally, patients known with ischemic heart disease before stroke onset had significantly lower first BP values than those without, which may be 
related to treatment.Univariate analyses suggested that high and low BP values were related to poor stroke outcome. However, multivariate analyses showed no significant relationship between the first $\mathrm{BP}$ measured directly after arrival at the first aid ward and the outcome at six months. When analysing only those BP values of patients that were admitted within 3 hours following stroke onset $(\mathrm{N}=138)$, we also could not establish a significant relationship between these first BP values and the functional outcome at six months. We found no evidence in favour of the idea that low or high early BP is a stroke outcome predictor. Small numbers may have failed to detect any (small size) relationship between BP extremes and outcome, but our data do not favour BP manipulation to serve as a potential therapy for acute stroke in general.

In chapter 5 we prospectively studied 24-hour monitored BP values, measured in ischemic stroke patients who were admitted within 24 hours following stroke onset. BP measurement was started within the first 24 hours after stroke onset. Of the 271 patients studied in chapter 4, 192 had over $80 \%$ of the 24-hour BP data capture. Of these 192 patients, we studied BP levels and diurnal variation. We found that per one year ageing, the absolute variation in systolic and diastolic BP significantly declined. Patients with a Rankin score 5 at admission showed a significantly lower absolute BP variation compared to patients with a Rankin score 1 or 2 . In accordance with this finding, patients with a CNS score 8-10 at admission showed a significantly higher absolute BP variation compared to patients with a CNS score $\leq 2$.

Twenty-four hour BP profiles showed lower BP values during nighttime hours and resting hours during the daytime. When studying the BP profiles for the different stroke subtypes (lacunar vs atherothrombotic vs cardioembolic infarcts), the BP profiles were quite similar in all three groups.

The first measured BP values were significantly higher than the mean of the 24hour BP values for all stroke subtypes. Lacunar infarct patients had significantly higher 24-hour and daytime systolic and diastolic BP than cardioembolic infarct patients. Furthermore, lacunar infarct patients had significantly higher absolute and percentage systolic and diastolic BP variation than cardioembolic and atherothrombotic infarct patients. We found a decrease in diurnal BP variation in most ischemic stroke patients. When studying the stroke subgroups, we found a larger diurnal variation in lacunar infarct patients. Furthermore, we found asymptomatic lacunar infarcts on CT to be independently related to a higher diurnal BP variation. This was in contrast with findings of others, who found a decrease in diurnal variation in lacunar stroke patients. We postulated that lacunar stroke, especially in the presence of asymptomatic infarcts on CT, may not be causally related to hypertension, and that in the presence of low BP values hypertension treatment may worsen, instead of prevent, ischemic brain damage in this lacunar stroke subtype.

In chapter 6 the prognostic value of the BP values of the 192 patients was tested. Univariate analysis of the first measured BP values of the 24-hour BP monitoring suggested that high and low BP values were related to poor outcome. Multivariate analyses, however, only showed a statistically significant relationship with poor outcome 
for patients with a first diastolic BP value $\leq 70 \mathrm{mmHg}$. However, when replacing the Rankin score on admission for the CNS score on admission in the multivariate analysis, the relationship with the outcome for a diastolic BP $\leq 70 \mathrm{mmHg}$ was not statistically significant anymore. We also found no relationship between the day- and nighttime BP values and the outcome at six months. Furthermore, no statistically significant associations were found between the diurnal BP variation and outcome and between the fall in BP during the first 4 days and the outcome at six months. We concluded that it is likely that in the vast majority of ischemic stroke patients, BP values are in a range that does not jeopardize penumbral tissue, and any relationship between BP extremes and stroke outcome is difficult to establish unless large numbers of patients, or only predefined subgroups with extremely high or low BP values are investigated. Similar reasoning may apply to the testing of early BP manipulation in an acute stroke trial.

In chapter 7 we studied the relationship between infarct location and size, and elevated $\mathrm{BP}$ (defined as a systolic BP $>140 \mathrm{mmHg}$ or a diastolic $\mathrm{BP}>90 \mathrm{mmHg}$ ) in acute stroke patients. Of the 271 patients studied in chapter 4, 106 patients underwent, besides a CT scan, an MRI scan of the brain. Forty-nine of the 106 patients had a symptomatic territorial (cortical) infarct, and 22 patients had a symptomatic lacunar infarct on MRI. Thirty-four $(69 \%)$ of the 49 patients had elevated BP on hospital admission. Twenty-five patients had a territorial infarct in the right-sided hemisphere, $16(64 \%)$ of these had elevated BP. Twenty-four patients had a territorial infarct in the left-sided hemisphere, $18(75 \%)$ of these had elevated BP. We found no statistically significant difference in number of patients with elevated BP between these two groups. The insular cortex was involved in the ischemic area in 29 of the 49 patients, and consequently, not in the 20 remaining patients. Eighteen (62\%) of these had elevated BP on admission. Of the 34 patients with elevated BP, 18 patients $(53 \%)$ had an infarct in the insular cortex (10 $(29 \%)$ in the right-sided insular cortex, $8(23 \%)$ in the left-sided insular cortex). Of the 15 patients without elevated BP, 11 patients $(73 \%)$ had an infarct in the insular cortex ( $7(47 \%)$ in the right-sided insular cortex, $4(27 \%)$ in the left-sided insular cortex). There was no statistically significant difference in the number of patients with elevated BP between the left- and right-sided insular infarcts. We also found no statistically significant difference in number of patients with elevated BP and an infarct involving the insular cortex, and patients without elevated BP and an infarct involving the insular cortex. Of the 22 lacunar stroke patients, 20 (91\%) had elevated BP on admission. When testing the relationship between different involved gyri (insular cortex, precentral gyrus or post-central gyrus), site or size of the infarct and elevated BP at admission in a multivariate analysis, we found no significant relationship between these variables. Furthermore, we found no statistically significant difference in absolute or percentage diurnal variation in systolic or diastolic BP between patients with a left- or right- sided cortical infarct or patients with or without an insular infarct.

Our findings argue against an important role of certain cortical areas, especially of the insular cortex, or of the degree of cerebral tissue damage in causing post-stroke BP elevation. We concluded that the integrity of connecting pathways of the sympathetic 
nervous system on the whole, underlies the mechanism for BP level control, rather than that a unique cerebral site would serve such function. It remains unclear what factors determine the normalisation of BP level and diurnal BP variation in the first week following stroke. 
10

Samenvatting 
Een beroerte (CVA) is een veel voorkomende aandoening. In Nederland krijgen ieder jaar ongeveer 30.000 mensen een beroerte. Op dit moment is thrombolyse de enige werkzame acute therapie voor patiënten met een ischemisch CVA. Echter, slechts 5 tot 10 procent van alle patienten met een ischemisch CVA komt in aanmerking voor thrombolyse. Een andere mogelijkheid om de prognose na een CVA te verbeteren zou kunnen bestaan uit het manipuleren van de hoogte van de bloeddruk (BD) in de acute fase van het CVA. Het is echter onbekend vanaf welke bloeddrukwaarden een behandeling gestart moet worden en naar welke bloeddrukwaarden gestreefd moet worden. Daarbij is het gevaarlijk de BD van alle patiënten op dezelfde manier te behandelen. Dit wordt verklaard aan de hand van de cerebrale autoregulatie die ervoor zorgt dat onder normale fysiologische omstandigheden bij bepaalde BD waarden, de regionale bloeddoorstroming in de hersenen constant wordt gehouden. Door een CVA raakt de cerebrale autoregulatie verstoord. Hierdoor is de doorstroming van de hersenen direct afhankelijk van de systemische BD. Hoge BD waarden kunnen daardoor leiden tot oedeem vorming of hemorrhagisch worden van het ischemisch gebied, met toename van de cerebrale schade tot gevolg. Lage BD waarden daarentegen, kunnen leiden tot uitbreiding van het ischemisch gebied, met eveneens toename van de cerebrale schade tot gevolg. Tot nu toe is weinig bekend over welke factoren onafhankelijke voorspellers zijn van de hoogte van de BD in de acute fase van het CVA, of welke BD karakteristieken onafhankelijke voorspellers van het functioneel herstel zijn. Voordat een klinisch onderzoek over BD behandeling in de acute fase van het CVA opgezet kan worden, zijn meer gegevens over dit onderwerp nodig.

In dit onderzoek hebben we verschillende factoren onderzocht, die samenhangen met de hoogte en het beloop van de BD in de acute fase van het CVA, en hebben we verschillende $\mathrm{BD}$ karakteristieken onderzocht die als onafhankelijke voorspellers van het functioneel herstel dienen.

In hoofdstuk 1 wordt een literatuur overzicht gegeven. De BD is in de acute fase van het CVA verhoogd bij 70 tot $94 \%$ van de patiënten. Deze verhoogde BD daalt spontaan gedurende de eerste week na het CVA. Gegevens over de prognostische waarde van de hoogte van de $\mathrm{BD}$ in de acute fase zijn tegenstrijdig: sommige onderzoekers vonden geen relatie tussen de hoogte van de BD en het functioneel herstel, terwijl anderen een relatie vonden tussen hoge of lage $\mathrm{BD}$ waarden en een slecht herstel.

In normotensieve personen is er een circadiaan BD patroon, waarbij de ochtend BD waarden hoger zijn dan de avond waarden, met een verdere daling van de BD gedurende de nacht. Een arbitrair gekozen absolute daling van $10 \mathrm{mmHg}$ of een relatieve daling van $10 \%$ tussen de dag- en nachtwaarde wordt 'dipping' genoemd. Bij de meeste CVA patiënten is de circadiane BD variatie verminderd. Gegevens over de prognostische waarde van de mate van de circadiane variatie in de acute fase van het CVA zijn eveneens tegenstrijdig.

In hoofdstuk 2 werden BD waarden bestudeerd van 409 patiënten die binnen 24 uur na het ontstaan van een eerste herseninfarct werden opgenomen. De BD waarden die binnen 
deze eerste 24 uur gemeten waren, werden retrospectief verzameld. Lineaire regressie analyses toonden aan dat de hoogte van de eerst gemeten BD na opname op de stroke unit een significante relatie had met de leeftijd, ischemische hartziekten en/of hypertensie in de voorgeschiedenis. Het CVA type (atherothrombotisch, lacunair of cardioembolisch) en Rankin score bij opname hadden geen significante relatie met de hoogte van de initiěle BD. Behalve de eerst gemeten BD na opname op de stroke unit, bestudeerden we verschillende karakteristieken van de gemiddelde dagwaarde (BD gemeten tussen 9.00 en 18.00 uur) en gemiddelde nachtwaarde (BD gemeten tussen 24.00 en 6.00 uur). Het beloop van de BD gedurende de eerste week na het ontstaan van het CVA werd bestudeerd. De BD daalde spontaan in deze eerste week, waarbij de grootste daling gedurende de eerste 3 dagen optrad. De nachtwaarden toonden eenzelfde beloop als de dagwaarden. Het BD beloop bij patiënten in een controlle groep was hetzelfde. Patiënten bekend met hypertensie in de voorgeschiedenis hadden hogere BD waarden gedurende de eerste week na het CVA dan patiënten zonder hypertensie in de voorgeschiedenis. Er was geen significant verschil in initiële $\mathrm{BD}$ hoogte en $\mathrm{BD}$ beloop tussen patiënten met een atherothrombotisch, cardioembolisch of lacunair infarct. Geconcludeerd werd dat de stijging van de $\mathrm{BD}$ post-CVA en daling van deze $\mathrm{BD}$ in de eerste week post-CVA geen algemene fenomenen zijn. Beide fenomenen treden onafhankelijk van het CVA type op. Aanwezigheid van hypertensie in de voorgeschiedenis is waarschijnlijk de grootste voorspeller van de BD stijging in de acute fase van het CVA.

In hoofdstuk 3 werd de prognostische waarde van de BD in de acute fase van het CVA bestudeerd. Hierbij werd gebruik gemaakt van dezelfde groep patiënten als in hoofdstuk 2. Als maat voor het functioneel herstel werd de Rankin score op 3 maanden gebruikt: voor een goede uitkomst (goed functioneel herstel) werd een Rankin score $\leq 3$ genomen, voor een slechte uitkomst (slecht functioneel herstel) een Rankin score $>3$. Univariate analyses toonden aan dat zowel hoge als lage $\mathrm{BD}$ waarden de neiging hadden een relatie te vertonen met een slecht functioneel herstel. Met behulp van multivariate analyses werd echter geen relatie aangetoond tussen de eerst gemeten BD na opname op de stroke unit en het functioneel herstel op 3 maanden. Ook werd er m.b.v. multivariate analyses geen relatie gevonden tussen de gemiddelde dag $\mathrm{BD}$ waarden en het functioneel herstel op 3 maanden. Wel werd er een significante associatie gevonden tussen een gemiddelde systolische nacht $\mathrm{BD}$ waarde $\geq 165 \mathrm{mmHg}$ en een gemiddelde diastolische nacht $\mathrm{BD}$ waarde $\leq 60 \mathrm{mmHg}$ en een slecht functioneel herstel: OR 2.8; $95 \%$ BI 1.1-6.8 resp. OR $8.1 ; 95 \% \mathrm{BI} 1.1-58.3$. Bij het bestuderen van de relatie tussen de daling van de $\mathrm{BD}$ in de eerste 4 dagen na het ontstaan van het CVA en het herstel op 3 maanden, vonden we een significante relatie tussen een daling $210 \mathrm{mmHg}$ en een slecht herstel: OR 3.0; $95 \% \mathrm{BI}$ 1.1-7.9. We concludeerden dat niet-gecorrigeerde hoge en lage $\mathrm{BD}$ waarden gerelateerd zijn aan een slechte outcome, en waarschuwden voor het ongecorrigeerd analyseren van eerste post-CVA BD waarden als voorspeller voor het functioneel herstel. Gemiddelde nachtelijke BD waarden zouden een onafhankelijke voorspellende waarde voor het functioneel herstel kunnen hebben. De resultaten lijken aan te geven dat verlagen van hoge $\mathrm{BD}$ waarden gunstig kan zijn, mits deze niet te drastisch verlaagd worden. Het 
verhogen van lage BD waarden lijkt eveneens zinvol. Een nadeel van deze retrospectieve studie is echter dat de relatie tussen de hoogte van de BD en het functioneel herstel overschat kan worden, daar er een bias opgetreden kan zijn door te hoge inclusie van patiënten met aanhoudende hoge of lage BD waarden.

In hoofdstuk 4 hebben we de prognostische waarde bestudeerd van de eerst gemeten BD waarde direct na aankomst op de EHBO (EHBO BD) bij 271 patiënten met een herseninfarct. Dit betrof een prospectief onderzoek waarbij patiënten binnen 24 uur na het ontstaan van het CVA werden geïncludeerd. Als afhankelijke uitkomst variabele (maat voor het functioneel herstel) werd de score van de Rankin handicap schaal 6 maanden na het ontstaan van het CVA genomen: voor een goede uitkomst (goed functioneel herstel) werd een Rankin score $\leq 3$ genomen, voor een slechte uitkomst (slecht functioneel herstel) een Rankin score $>3$. Patiënten bekend met hypertensie in de voorgeschiedenis bleken een signiticant hogere systolische EHBU BD waardè te hiebbien dan patiënten niet bekend met hypertensie. Mannen hadden een significant hogere systolische en diastolische EHBO BD waarde dan vrouwen. Met het stijgen van de leeftijd, nam de systolische EHBO BD waarde significant toe. Patiënten met asymptomatische lacunaire infarcten op de CT scan hadden significant hogere systolische en diastolische $\mathrm{EHBO} \mathrm{BD}$ waarden dan patiënten zonder asymptomatische lacunaire infarcten op de CT. Patiënten die bekend waren met ischemische hartziekten in de voorgeschiedenis hadden significant lagere EHBO BD waarden dan patiënten die hier niet mee bekend waren. Deze laatste bevinding zou gerelateerd kunnen zijn aan de medicamenteuze behandeling. Bij univariate analyses werd een trend gevonden waarbij zowel hoge als lage EHBO BD waarden gerelateerd waren aan een slecht functioneel herstel. Multivariate analyses toonden echter geen significante relatie tussen deze EHBO $\mathrm{BD}$ waarden en het functioneel herstel op 6 maanden. Wanneer alleen de $\mathrm{BD}$ waarden van patiënten die binnen 3 uur na het ontstaan van het CVA op de EHBO waren geanalyseerd werden $(\mathrm{N}=138)$, kon eveneens geen significante associatie tussen de DB en het functioneel herstel aangetoond worden. Concluderend konden we geen ondersteuning vinden voor de theorie dat een hoge of lage bloeddruk een onafhankelijke voorspeller is van het functioneel herstel. Mogelijk had er een (welliswaar kleine) relatie tussen de BD en het herstel aangetoond kunnen worden wanneer de onderzochte patiëntenpopulatie groter was geweest. Onze resultaten ondersteunen manipulatie van de BD als vorm van acute behandeling, om de prognose na een CVA te verbeteren, echter niet.

In hoofdstuk 5 werden prospectief 24-uurs gemeten BD waarden bestudeerd, die om het half uur gemeten waren binnen 24 uur na het ontstaan van een ischemisch CVA. Van de 271 patiënten die bestudeerd werden in hoofdstuk 4, waren bij 192 patiënten meer dan $80 \%$ van de 24 -uurs $\mathrm{BD}$ waarden geregistreerd. Bij deze 192 patiënten werd de hoogte en de circadiane variatie van de BD bestudeerd. Met het stijgen van de leeftijd daalde de absolute variatie in systolische en diastolische BD significant. Patiënten met een Rankin score 5 bij opname hadden een significant lagere absolute BD variatie vergeleken met patiënten met een Rankin score 1 of 2 bij opname. In overeenstemming met deze 
bevinding, hadden patiènten met een CNS score 8-10 bij opname een significant hogere absolute $\mathrm{BD}$ variatie vergeleken met patiēnten met een $\mathrm{CNS}$ score $\leq 2$ bij opname. 24-uurs $\mathrm{BD}$ profielen toonden lagere $\mathrm{BD}$ waarden gedurende de nachtelijke uren en rust uren overdag vergeleken met de rest van de daguren. De $\mathrm{BD}$ profielen van de verschillende CVA typen (lacunaire vs atherothrombotische vs cardioembolische infarcten) vertoonden een gelijk patroon. De eerst gemeten BD waarde van de 24-uurs registratie was significant hoger dan de gemiddelde 24-uurs BD waarde. Patiënten met een lacunair infarct hadden significant hogere gemiddelde 24-uurs- en systolische en diastolische dag BD waarden dan patiënten met een cardioembolisch infarct. Verder hadden patiënten met een lacunair infarct een significant hogere absolute en relatieve systolische en diastolische BD variatie dan patiënten met een cardioembolisch of atherothrombotisch infarct. De meeste CVA patiënten hadden een verminderde dag en nacht $\mathrm{BD}$ variatie in de acute fase. Patiënten met een lacunair infarct hadden de grootste variatie in dag en nacht BD. De aanwezigheid van asymptomatische lacunaire infarcten op CT was onafhankelijk gerelateerd aan een grotere diurnale $\mathrm{BD}$ variatie. Dit strookt niet met de bevindingen van andere onderzoekers die een daling van de diurnal BD variatie vonden bij lacunaire infarct patiënten. Wij stelden dat lacunaire infarcten, speciaal in de aanwezigheid van asymptomatische lacunaire infarcten op $\mathrm{CT}$, waarschijnlijk niet causaal gerelateerd zijn aan hypertensie, en dat antihypertensieve therapie, in aanwezigheid van lage BD waarden, ischemische cerebrale schade kan verergeren i.p.v. voorkomen.

In hoofdstuk 6 werd de prognostische waarde van BD metingen van 192 patiënten onderzocht. Univariate analyses van de eerst gemeten BD waarde van de 24-uurs BD registratie gaf de indruk dat hoge en lage BD waarden gerelateerd waren aan een slecht functioneel herstel. Multivariate analyses lieten echter alleen een statistisch significante relatie met een slecht functioneel herstel zien voor een eerst gemeten diastolische BD waarde $\leq 70 \mathrm{mmHg}$. Deze relatie was echter niet meer significant wanneer in de multivariate analyses de Rankin score bij opname vervangen werd door de CNS score bij opname. Er werd ook geen relatie gevonden tussen de dag en nacht BD waarden en het herstel op 6 maanden. Verder werden er geen statistisch significante associaties gevonden tussen de diurnale BD variatie of de daling van de BD gedurende de eerste 4 dagen en het herstel op 6 maanden. Wij concludeerden dat bij het grootste gedeelte van patiënten met een ischemisch CVA, de BD zich in een range bevindt die geen gevaar voor de penumbra oplevert. Een relatie tussen BD uitersten en het herstel is moeilijk vast te stellen behalve wanneer wellicht grote groepen patiënten, of duidelijk gedefiniëerde subgroepen met zeer hoge of lage BD waarden onderzocht zouden worden. Hetzelfde geldt voor het testen in trial verband van het manipuleren van de $\mathrm{BD}$ in de acute fase van het CVA.

In hoofdstuk 7 werd de relatie tussen de locatie en grootte van het infarct en verhoogde $\mathrm{BD}$ (gedefiniëerd als een systolische waarde $>140 \mathrm{mmHg}$ en/of een diastolische waarde $>90 \mathrm{mmHg}$ ) bestudeerd in de acute fase van het CVA. Van de 271 patiënten die in hoofdstuk 4 bestudeerd werden, kregen 106 patiënten, naast een CT, een MRI scan van de hersenen. Negenenveertig van deze 106 patiënten hadden een corticaal infarct, 
22 hadden een lacunair infarct op de MRI. Vierendertig (69 \%) van de 49 patiënten hadden een verhoogde BD bij opname in het ziekenhuis. Vijfentwintig patiënten hadden een rechtszijdig corticaal infarct, $16(64 \%)$ van deze hadden een verhoogde BD. Vierentwintig patiënten hadden een linkszijdig corticaal infarct, 18 (75\%) hiervan hadden een verhoogde BD. Er was geen statistisch significant verschil in aantal patiënten met een verhoogde $\mathrm{BD}$ tussen deze 2 groepen. De insulaire cortex was betrokken bij het infarct in 29 van de 49 patiënten. Achttien (62\%) hiervan hadden een verhoogde BD bij opname. Van de 34 patiënten met een verhoogde $\mathrm{BD}$, hadden $18(53 \%)$ een infarct in de insulaire cortex $(10(29 \%)$ in de rechter en $8(23 \%)$ in de linker insulaire cortex). Van de 15 patiënten zonder verhoogde BD hadden $11(73 \%)$ een infarct in de insulaire cortex ( 7 ( $47 \%$ ) in de rechter, 4 (27\%) in de linker insulaire cortex). Er was geen statistisch significant verschil in aantal patiënten met een verhoogde BD tussen links- en rechtszijdige infarcten. Ook vonden we geen statistisch significant verschil in aantal patiënten met een verhoogde $\mathrm{BD}$ en een infarct in de insulaire cortex, en patiënten zonder verhoogde $\mathrm{BD}$ en een infarct in de insulaire cortex. Van de 22 patiënten met een lacunair infarct hadden er $20(91 \%)$ een verhoogde $\mathrm{BD}$ bij opname. Bij het testen van de relatie tussen de verschillende aangedane gyri (insulaire cortex, precentrale gyrus of postcentrale gyrus), zijde of grootte van het infarct en de verhoogde BD bij opname, werd geen significante relatie tussen deze variabelen gevonden. Verder werd er geen statistisch significant verschil tussen de absolute of relatieve diurnale variatie in systolische of diastolische BD gevonden tussen patiënten met een links- of rechtszijdig corticaal infarct of patiënten met of zonder een infarct in de insulaire cortex.

Onze bevindingen pleiten tegen een belangrijke rol van bepaalde corticale gebieden, in het bijzonder de insulaire cortex, of de hoeveelheid cerebrale weefsel beschadiging bij het ontstaan van de post-CVA BD verhoging. Wij concludeerden dat de integriteit van de verbindende banen van het sympatische zenuwstelsel in het geheel, ten grondslag ligt aan het mechanisme van BD controle, i.p.v. een unieke cerebrale localisatie. Het blijft onduidelijk welke factoren de normalisatie van het $\mathrm{BD}$ niveau en diurnale $\mathrm{BD}$ variatie in de eerste week na het CVA bepalen. 


\section{Appendix}

\section{The Modified Rankin Scale}

0: no symptoms

1: minor symptoms that do not interfere with lifestyle

2: minor handicap--> symptoms that lead to some restriction in lifestyle but do not interfere with the patient's capacity to look after him-/herself

3: moderate handicap--> symptoms that significantly restrict lifestyle and prevent totally independent existence

4 : moderate to severe handicap $->$ symptoms that clearly prevent independent existence though not needing constant attention

5: severe handicap $-\rightarrow$ totally dependent, requiring constant attention night and day

6: deceased

\section{The Canadian Neurological Scale}

\section{Mentation}

1.Level of consciousness

- alert

- drowsy

2. Orientation

- oriented

- disoriented or non applicable 0

3. Speech

- normal

- expressive deficit

- receptive deficit

0

\section{Motor function (no comprehension deficit)}

4a. Face

- none

0.5

- present

0

5a. Arm:proximal

- none

- mild

- significant

- total

6a. Arm:distal

- none

- mild

- significant

- total 
7a. Leg

- none

- mild

- significant

- total

Motor response (comprehension deficit)

4b. Face

- symmetrical

0.5

- asymmetrical

0

5b. Arms

- equal

- unequal

0

6b. Legs

- equal

1.5

- unequal 


\section{References}

1. Fact sheet Nederlandse Hartstichting. Hart en vaatziekten in Nederland 1999: cijfers over ziekte en sterfte. 1999.

2. Bogousslavsky J, Kaste M, Skyhoj Olsen T, Hacke W, Orgogozo J-M for the EUSI Executive Committee. Risk factors and stroke prevention. Cerebrovasc Dis 2000;10 (suppl 3):12-21.

3. Wolf PA, Belanger AJ, D'Agostino RB. Quantifying stroke risk factors and potentials for risk reduction. Cerebrovasc Dis 1993;3 (suppl 1):7-14.

4. Herman B, Leyten ACM, Luijk van JH, Frenken CWGM, Op de Coul AAW, Schulte BPM. Epidemiology of stroke in Tilburg, the Netherlands. The population-based stroke incidence register: 2 . Incidence, initial clinical picture and medical care, and three week case fatality. Stroke 1982;13:629-634.

5. Foulkes MA, Wolf PA, Price TR, Mohr JP, Hier DB. The Stroke Data Bank: Design, methods, and baseline characteristics. Stroke 1988;19:547-554.

6. Davenport R, Dennis M. Neurological emergencies:acute stroke. J Neurol Neurosurg Psychiatry 2000;68:277-288.

7. European Stroke Initiative. European Stroke Initiative Recommendations for stroke management. Cerebrovasc Dis 2000;10:335-351.

8. Humphrey P. Stroke and transient ischaemic attacks. J Neurol Neurosurg Psychiatry 1994;57:534-543.

9. Rigaud AS, Seux ML, Staessen JA, Birkenhäger WH, Forette F. Cerebral complications of hypertension. J Hum hypertens 2000;14:605-616.

10. Evers SMAA, Engel GL, Ament AJHA. Cost of stroke in The Netherlands from a societal perspective. Stroke 1997;28:1375-1381.

11. Carstairs V. Stroke: Resource consumption and the cost to the community. In: Gillingham FJ, Mawdsley C, Williams AE (eds). Stroke. Proceedings of the Ninth International Pfizer Symposium. Edinburgh: Churchill Livingstone, 1976:516528.

12. Adelman SM. National survey of stroke: Economic impact. Stroke 1981;12 (suppl 1):I-69-I-88.

13. Lodder J, Bouter LM. Toekomstige aantallen patiënten met een cerebrovasculair accident in Nederland. Ned Tijdschr geneeskd 1992;136:425-428.

14. Palmer AJ, Bulpitt CJ, Fletcher AE, Beevers DG, Coles EC, Ledingham JGG, O'Riordan PW, Petrie JC, Rajagopalan BE, Webster J, Dollery CT. Relation between blood pressure and stroke mortality. Hypertension 1992;20:601-605.

15. Cruickshank JM, Higgins TJC, Pennert K, Thorp JM, Zacharias FM, Zacharias FJ. The efficacy and tolerability of antihypertensive treatment based on atenolol in the prevention of stroke and the regression of left ventricular hypertrophy. J Hum hypertens 1987;1:87-93.

16. The European Atrial Fibrillation Study Group. Optimal oral anticoagulation therapy with nonrheumatic atrial fibrillation and recent cerebral ischemia. $N$ Engl JMed 1995;333:5-10. 
17. Koudstaal P. Anticoagulants for preventing stroke in patients with nonrheumatic atrial fibrillation and a history of stroke or transient ischemic attacks (Cochrane Review). In:The Cochrane Library 1999 (Issue 4).

18. Koudstaal P. Anticoagulants versus antiplatelet therapy for preventing stroke in patients with nonrheumatic atrial fibrillation and a history of stroke or transient ischemic attacks (Cochrane Review). In:The Cochrane Library 1999 (Issue 4).

19. Antiplatelet Trialists' Collaboration. Collaborative overview of randomised trials of antiplatelet therapy-I: Prevention of death, myocardial infarction, and stroke by prolonged antiplatelet therapy in various categories of patients. BMJ 1994;308:81106.

20. Gubitz G, Counsell C, Sandercock P, et al. Anticoagulants in acute ischaemic stroke (Cochrane Review). In:The Cochrane Library 1999 (Issue 4).

21. Diener HC, Cunha L, Forbes C, Sivenius J, Smets P, Lowenthal A. European stroke prevention study. 2. Dipyridamole and acetylsalicylic acid in the secondary prevention of stroke. J Neurol Sci 1996;143:1-13.

22. CAPRIE Steering Committee. A randomised, blinded, trial of clopidogrel versus aspirin in patients at risk of ischaemic events (CAPRIE). Lancet 1996;348:13291339.

23. North American Symptomatic Carotid Endarterectomy Trial Collaborators. Beneficial effect of carotid endarterectomy in symptomatic patients with highgrade carotid stenosis. $N$ Engl J Med 1991;325:445-453.

24. European Carotid Surgery Trialists' Collaborative Group. Randomised trial of endarterectomy for recently symptomatic carotid stenosis: final results of the MRC European Carotid Surgery Trial (ECST). Lancet 1998;351:1379-1387.

25. Barnett HJM, Taylor DW, Eliasziw M, Fox AJ, Ferguson GG, Haynes RB, Rankin RN, Clagett GP, Hachinski VC, Sackett DL, Thorpe KE, Math M, Meldrum HE for the North American Symptomatic Carotid Endarterectomy Trial Collaborators. Benefit of carotid endarterectomy in patients with symptomatic moderate or severe stenosis. N Engl J Med 1998;339:1415-1425.

26. Lang W, Domanovits H, Gorzer H. Ischemic stroke: new ways of treatment. Acta Med Austriaca 1999;26(2):57-69.

27. Grau AJ, Ruf A, Vogt A, Lichy C, Buggle F, Patscheke H, Hacke W. Increased fraction of circulating activated platelets in acute and previous cerebrovascular ischemia. Thromb Haemost 1998;80:298-301.

28. White HD, Simes RJ, Anderson NE, Hankey GJ, Watson JDG, Hunt D, et al. Pravastatin therapy and the risk of stroke. N Engl J Med 2000;343:317-326.

29. Blauw GJ, Lagaay AM, Smelt AHM, Westendorp RGJ. Stroke, statins and cholesterol: A meta-analysis of randomized, placebo controlled, double-blind trials with HMG-CoA reductase inhibitors. Stroke 1997;28:946-50.

30. Wardlaw J, Warlow C. Thrombolytic therapy for acute ischaemic stroke. The updated Cochrane database of systemic reviews meta-analysis. Cerebrovasc Dis 1999;9:124. 
31. Wardlaw JM, Warlow CP, Counsell C. Systematic review of evidence on thrombolytic therapy for acute ischaemic stroke. Lancet 1997;350:607-614.

32. The National Institute of neurological Disorders and Stroke rt-PA Stroke Study Group (NINDS). Tissue plasminogen activator for acute ischemic stroke. N Engl JMed 1995;333:1581-1587.

33. Hacke W, Kaste M, Skyhoj Olsen T, Bogousslavsky J, Orgogozo J-M for the EUSI Executive Committee. Acute treatment of ischemic stroke. Cerebrovasc Dis 2000;10(suppl 3):22-33.

34. Boiten J, Wilmink JT, Lodder J, Troost J. Trombolyse bij patiënten met een acuut herseninfarct:gunstige eerste ervaringen in Maastricht. Ned Tijdschr geneeskd 2000; 144(22):1062-1069.

35. The European Ad Hoc Consensus Group. Optimizing intensive Care in Stroke: A European Perspective. A report of an Ad Hoc Consensus Group Meeting. Cerebrovasc Dis 1997;7:113-128.

36. Castillo J, Dávalos A, Marrugat J, Noya M. Timing for fever-related brain damage in acute ischemic stroke. Stroke 1998;29:2455-2460.

37. Reith J, Jørgensen H, Pedersen P, Nakayama H, Raaschou H, Jeppesen L, et al. Body temperature in acute stroke: Relation to stroke severity, infarct size, mortality and outcome. Lancet 1996;347:422-425.

38. Pulsinelli W, Levy D, Sigsbee B, Scherer P, Plum F. Increased damage after ischemic stroke in patients with hyperglycemia with or without established diabetes mellitus. Am JMed 1983;74:540-544.

39. O' Mahony D, Kendall MJ. Nitric oxide in acute ischaemic stroke: a target for neuroprotection. J Neurol Neurosurg Psychiatry 1999;67:1-3.

40. Lodder J, Luijckx GJ, van Raak L, Kessels F. Diazepam treatment to increase the cerebral GABAergic activity in acute stroke: a feasibilty study in 104 patients. Cerebrovasc Dis 2000;10:437-440.

41. O'Connell JE, Gray CS. Treating hypertension after stroke. BMJ 1994;308:15231524.

42. Powers WJ. Acute hypertension after stroke: The scientific basis for treatment decisions. Neurology 1993;43:461-467.

43. Lavin P. Management of Hypertension in patients with acute stroke. Arch Int Med 1986;146:66-68.

44. Feldmann E, Skolnick BE. Cerebral hemodynamics, autoregulation, and blood pressure management. J Stroke Cerebrovasc Dis 1999;8(3):176-182.

45. Van den Meiracker AH. Hypertensie in de acute fase van het herseninfarct; meestal niet behandelen. Ned Tijdschr Geneesk 1997;141(22):1089-1092.

46. Carlberg B, Asplund K, Hägg E. The prognostic value of admission blood pressure in patients with acute stroke. Stroke 1993;24:1372-1375.

47. Carlberg B, Asplund K, Hägg E. Factors influencing admission blood pressure levels in patients with acute stroke. Stroke 1991;22:527-530.

48. Robinson T, Waddington A, Ward-Close S, Taub N, Potter J. The predictive role of 24-hour compared to casual blood pressure levels on outcome following acute stroke. Cerebrovasc Dis 1997;7:264-272. 
49. Phillips SJ. Pathophysiology and management of hypertension in acute ischemic stroke. Hypertension 1994;23(1):131-136.

50. Dandapani BK, Suzuki S, Kelley RE, Reyes-Iglesias Y, Duncan RC. Relation between blood pressure and outcome in intracerebral hemorrhage. Stroke 1995;26:21-24.

51. Dawson SL, Blake MJ, Panerai RB, Potter JF. Dynamic but not static cerebral autoregulation is impaired in acute ischaemic stroke. Cerebrovasc dis 2000;10:126-132.

52. Schrader J, Rőthemeyer M, Lüders S, Kollmann K. Hypertension and strokerationale behind the ACCESS trial. Basic Res Cardiol 1998;93 (suppl 2):69-78.

53. Dawson SL, Manktelow BN, Robinson TG, Panerai RB, Potter J, F. Which parameters of beat-to-beat blood pressure and variability best predict early outcome after acute ischemic stroke. Stroke 2000;31:463-468.

54. Britton M, Carlsson A, de Faire U. Blood pressure course in patients with acute stroke and matched controls. Stroke 1986;17:861-864.

55. Loyke HF. Lowering of blood pressure after stroke. Am J Med Sci 1983;286:2-11.

56. Loyke HF. The three phases of blood pressure in stroke. South Med J 1990;83(6):660-663.

57. Jørgensen HS, Nakayama H, Olsen TS. Treatment of arterial hypertension in acute stroke. In: Castillo J, Dávalos A, Toni D. Management of acute ischemic stroke. Springer-Verlag Iberica; Barcelona 1997 p81-87.

58. Wallace JD, Levy LL. Blood pressure after stroke. JAMA 1981;246:2177-2180.

59. Lip GYH, Zarifis J, Farooqi IS, Page A, Sagar G, Beevers DG. Ambulatory blood pressure monitoring in acute stroke: The West Birmingham Stroke Project. Stroke 1997;28:31-35.

60. Morfis L, Schwartz RS, Poulos R, Howes LG. Blood pressure changes in acute cerebral infarction and hemorrhage. Stroke 1997;28:1401-1405.

61. Jansen PAF, Thien T, Gribnau FWJ, Schulte BPM, Willemsen JJ, Lamers KJB, Poels EFJ. Blood pressure and both venous and urinary catecholamines after cerebral infarction. Clin Neurol Neurosurg 1988;90-1:41-45.

62. Jansen PAF, Schulte BPM, Poels EFJ, Gribnau FWJ. Course of blood pressure after cerebral infarction and transient ischemic attack. Clin Neurol Neurosurg 1987;89-4:243-246.

63. Carlsson A, Britton M. Blood pressure after stroke: a one-year follow-up study. Stroke 1993;24:195-199.

64. Chamorro A, Vila N, Ascaso C, Elices E, Schonewille W, Blanc R. Blood pressure and functional recovery in acute ischemic stroke. Stroke 1998;29:18501853.

65. Bath FJ, Bath PMW. What is the correct management of blood pressure in acute stroke? The Blood Pressure in Acute Stroke Collaboration. Cerebrovasc Dis 1997;7:205-213. 
66. Yosefy C, Linov L, Viskoper JR, Hay E, Jafari J, Nasri Y, Peled R, Reisin L. Prior antihypertensive treatment and admission blood pressure correlated with clinical outcome and early morning presentation in hypertensive ischaemic stroke patients. J Hum Hypertens 1999;13 :765-769.

67. Harper G, Castleden CM, Potter JF. Factors affecting changes in blood pressure after acute stroke. Stroke 1994;25:1726-1729.

68. Lisk DR, Grotta JC, Lamki LM, Tran HD, Taylor JW, Molony DA, Barron BJ. Should hypertension be treated after acute stroke? A randomized controlled trial using single photon emission computed tomography. Arch Neurol 1993; 50:855862.

69. Morfis L, Schwartz R, Lykos D, Zagami A, Pryor D, Howes LG. 24 hour ambulatory blood pressure profiles in the acute phase of stroke. Clin Exp Pharmacol Physiol 1995;22:775-777.

70. Adams GF. Prospects for patients with strokes, with special reference to the hypertensive hemiplegic. BMJ 1965;ii:253-259.

71. Droller H. The outlook in hemiplegia. Geriatrics 1965;20:630-636.

72. Jørgensen HS, Reith J, Nakayama H, Kammersgaard LP, Raaschou HO, Skyhøj Olsen T. What determines good recovery in patients with the most severe strokes? The Copenhagen Stroke Study. Stroke 1999;30:2008-2012.

73. Britton M, Rödén A. Progression of stroke after arrival at hospital. Stroke 1985;16:629-632.

74. Dávalos A, Cendra E, Teruel J, Martinez M, Genis D. Deteriorating ischemic stroke: Risk factors and prognosis. Neurology 1990;40:1865-1869.

75. Britton M, Carlsson A. Very high blood pressure in acute stroke. J Int Med 1990;228:611-615.

76. Hénon H, Godefroy O, Leys D, Mournier-Vehier F, Lucas C, Rondepierre P, Duhamel A, Pruvo JP. Early predictors of death and disability after acute cerebral ischemic event. Stroke 1994;26:392-398.

77. Allen CMC. Predicting the outcome of acute stroke: a prognostic score. J Neurol Neurosurg Psych 1984;47:475-480.

78. Millar-Craig M, Bishop C, Raftery E. Diurnal variation in blood pressure. Lancet 1978;1:795-797.

79. Schrader J, Schoel G, Kandt M, Warneke G, Ruschitzka F, Rath W, Scheler F. Bedeutung der 24-Stunden-Blutdruckmessung bei sekundärer Hypertonie. $Z$ Kardiol 1991;80(Suppl. 1):21-27.

80. Manning G, Rushton L, Millar-Graig MW. Twenty-four hour ambulatory blood pressure: a sample from a normal British population. $J$ Hum hypertens 1998;12:123-127.

81. Lago A, Geffner D, Tembl J, Landete L, Valero C, Baquero M. Circadian variation in acute ischemic stroke: a hospital-based study. Stroke 1998;29:1873-1875.

82. Elliott WJ. Circadian variation in blood pressure. Implications for the elderly patient. Am J Hypertens 1999;12:43S-49S. 
83. O'Shea JC, Murphy MB. Nocturnal blood pressure dipping: a consequence of diurnal physical activity blipping? Am J Hypertens 2000;13:601-606.

84. Verdecchia P, Porcellati C, Schillaci G, Borgioni C, Ciucci A, Battistelli M, Guerrieri M, Gatteschi C, Zampi I, Santucci A, Santucci C, Reboldi G. Ambulatory blood pressure: an independent predictor of prognosis in essential hypertension. Hypertens 1994;24:793-801.

85. Mansoor GA, White WB. Ambulatory blood pressure monitoring in cerebrovascular and retinal vascular disease. J Stroke Cerebrovasc Dis 1997;6(5):313-318.

86. Dawson SL, Evans SN, Manktelow BN, Fotherby MD, Robinson TG, Potter JF. Diurnal blood pressure change varies with stroke subtype in the acute phase. Stroke 1998;29:1519-1524.

87. Schillaci G, Verdecchia P, Borgioni C, Ciucci A, Gattobigio R, Sacchi N, Benemio G, Porcellati C. Predictors of diurnal blood pressure changes in 2042 subjects with essential hypertension. J Hypertens 1996;14:1167-1173.

88. Kukla C, Sander D, Schwarze J, Wittich I, Klingelhöfer J. Changes of circadian blood pressure patterns are associated with the occurence of lacunar infarction. Arch Neurol 1998;55:683-688.

89. Yamamoto Y, Akiguchi I, Oiwa K, Hayashi M, Kimura J. Adverse effect of nighttime blood pressure on the outcome of lacunar infarct patients. Stroke 1998;29:570-576.

90. Fujishima S, Abe I, Okada Y, Saku Y, Sadoshima S, Fujishima M. Serial changes in blood pressure and neurohormone levels after the onset of lacunar stroke. Angiol J Vasc Dis 1996;47(6):579-587.

91. Sander D, Klingelhöfer J. Changes of circadian blood pressure patterns and cardiovascular parameters indicate lateralisation of sympathetic activation following hemispheric brain infarction. $J$ Neurol 1995;242:313-138.

92. Sander D, Klingelhöfer J. Changes of circadian blood pressure patterns after hemodynamic and thromboembolic brain infarction. Stroke 1994;25:1730-1737.

93. Yamamoto Y, Akiguchi I, Oiwa K, Satoi H, Kimura J. Diminished nocturnal blood pressure decline and lesion site in cerebrovascular disease. Stroke 1995;26:829-833.

94. Lin L-J, Tseng Y-Z, Chiang F-T, Lee T-K, Tseng W-P. Altered circadian rhythm of blood pressure in patients with cerebral stroke. Am J Noninv Cardiol 1992;6:6265 ,

95. Robinson TG, James M, Youde J, Panerai R, Potter J. Cardiac baroreceptor sensitivity is impaired after acute stroke. Stroke 1997;28:1671-1676.

96. Sander D, Klingelhöfer J. Extent of autonomic activation following cerebral ischemia is different in hypertensive and normotensive humans. Arch Neurol 1996;53:890-894.

97. Robinson T, Ward-Close S, Potter J. A comparison of beat-to-beat blood pressure variability in acute and subacute stroke patients with cerebral infarction.

Cerebrovasc Dis 1997;7:214-219. 
98. Nakamura K, Oita J, Yamaguchi T. Nocturnal blood pressure dip in stroke survivors: a pilot study. Stroke 1995;26:1373-1378.

99. Maeda Y, Ikeda U, Ebata H, Hojo Y, Nakagami H, Shimada K. Diurnal blood pressure rhythm in hypertensives with parental history of stroke. Am J Hypertens 1997; 10:562-564.

100. Chamorro A, Saiz A, Vila N, Ascaso C, Blanc R, Alday M, Pujol J. Contribution of arterial blood pressure to the clinical expression of lacunar infarction. Stroke 1996;27:388-392.

101. Tohgi H, Chiba K, Kimura M. Twenty-four-hour variation of blood pressure in vascular dementia of the binswanger type. Stroke 1991;22:603-608.

102. Shimada K, Kawamato A, Matsubayashi K, Ozawa T. Silent cerebrovascular disease in the elderly:correlation with ambulatory pressure. Hypertens 1990;16:692-699.

103. Watanabe N, Imai Y, Nagai K, Tsuji I, Satoh H, Sakuma M, Sakuma H, Kato J, Onodera-Kikuchi N, Yamada M, Abe F, Hisamichi S, Abe K. Nocturnal blood pressure and silent cerebrovascular lesions in elderly Japanese. Stroke 1996;27:1319-1327.

104. Kario K, Matsuo T, Kobayashi H, Imiya M, Matsuo M, Shimada K. Nocturnal fall of blood pressure and silent cerebrovascular damage in elderly hypertensive patients. Hypertens 1996;27:130-135.

105. Shimada K, Kawamoto A, Matsubayashi K, Nishinaga M, Kimura S, Ozawa T. Diurnal blood pressure variations and silent cerebrovascular damage in elderly patients with hypertension. J Hypertens 1992;10:875-878.

106. Carlberg B, Asplund K, Hagg E. High blood pressure in acute stroke: is it "white coat" hypertension? J Intern Med 1990;228:291-292.

107. Carlberg B, Asplund K, Hägg E. Course of blood pressure in different subsets of patients after acute stroke. Cerebrovasc dis 1991;1:281-287.

108. Harper G, Fotherby MD, Panayiotou BJ, Castleden CM, Potter JF. The changes in blood pressure after acute stroke: abolishing the 'white coat effect' with 24-h ambulatory monitoring. $J$ Int Med 1994;235:343-346.

109. Sander D, Klingelhöfer J. Stroke-associated pathological sympathetic activation related to size of infarction and extent of insular damage. Cerebrovasc Dis 1995;5:381-385.

110. Vokó Z, Bots ML, Hofman A, Koudstaal PJ, Witteman JCM, Breteler MMB. Jshaped relation between blood pressure and stroke in treated hypertensives. Hypertens 1999;34:1181-1185.

111. Ohkubo T, Hozawa A, Nagai K, Kikuya M, Tsuji I, Ito S, Satoh H, Hisamichi S, Imai Y. Prediction of stroke by ambulatory blood pressure monitoring versus screening blood pressure measurements in a general population: the Ohasama study. J Hypertens 2000;18:847-854. 
112. Collins R, Peto P, MacMahon S, Herbert P, Fiebach N, Eberlein K. Blood pressure, stroke, and coronary heart disease. 2. Short-term reductions in blood pressure: Overview of randomised drug trials in their epidemiological context. Lancet 1990;335:827-838.

113. Brown MJ, Haydock S. Pathoaetiology, epidemiology and diagnosis of hypertension. Drugs 2000;59(Suppl 2):1-12.

114. Dyker AG, Grosset DG, Lees K. Perindopril reduces blood pressure but not cerebral blood flow in patients with recent cerebral ischemic stroke. Stroke 1997;28:580-583.

115. Kernan WN, Viscoli CM, Brass LM, Makuch RW, Sarrel PM, Horwitz RI. Blood pressure exceeding national guidelines among women after stroke. Stroke 2000;31:415-419.

116. SHEP Cooperative Research Group. Prevention of stroke by antihypertensive drug treatment in older persons with isolated systolic hypertension. Final results of the Systolic Hypertension in the Elderly Program (SHEP). JAMA 1991;265:3255-3264.

117. Staessen JA, Fagard R, Thijs L, Celis H, Arabidze GG, Birkenhäger WH, Bulpitt CJ, de Leeuw PW, Dollery CT, Fletcher AE, Forette F, Leonetti G, Nachev C, O'Brien ET, Rosenfeld J, Rodicio JL, Tuomilehto J, Zanchetti A for the Systolic Hypertension in Europe (Syst-Eur) Trial Investigators. Randomised double-blind comparison of placebo and active treatment for older patients with isolated systolic hypertension. Lancet 1997;350:757-764.

118. Gueyffier F, Boissel JP, Boutitie F, Pocock S, Coope J, Cutler J, Ekbom T, Fagard R, Friedman L, Kerlikowske K, Perry M, Prineas R, Schron E. Effect of antihypertensive treatment in patients having already suffered from stroke. Gathering the evidence. The INDANA (INdividual Data ANalysis of Antihypertensive intervention trials) Project Collaborators. Stroke 1997;28:25572562 .

119. Fagan SC, Gengo FM, Bates V, Levine SR, Kinkel WR. Effect of nimodipine on blood pressure in acute ischemic stroke in humans. Stroke 1988;19:401-402.

120. Uzner N, Ozdemir G, Gucuyener D. The interaction between nimodipine and systemic blood pressure and pulse rate. WHO Consensus Conf, Helsingborg, 1995.

121. Britton M, de Faire U, Helmers C. Hazards of therapy for excessive hypertension in acute stroke. Act Med Scan 1980;207:253-257.

122. Hachinski V. Hypertension in acute ischemic stroke. Arch Neurol 1985;42:1002.

123. Oppenheimer S, Hachinski V. Complications of acute stroke. Lancet 1992;339:721-724.

124. Strandgaard S, Paulson OB. Cerebrovascular consequences of hypertension. Lancet 1994;344:519-521.

125. Adams HP, Brott T, Crowell RM, Furlan AJ, Gomez CR, Grotta J. Guidelines for the management of patients with acute stroke. Stroke 1994;25:1901-1904. 
126. Blood pressure in Acute Stroke Collaboration (BASC). Interventions for deliberately altering blood pressure in acute stroke. In: The Cochrane Library 1999 (Issue 4).

127. Bennet NE. Hypertension in the elderly. Lancet 1994;344:447-449.

128. The sixth report of the Joint National Committee on prevention, detection, evaluation, and treatment of high blood pressure. Arch Intern Med 1997;157:2413-2446.

129. Allen CMC. Clinical diagnosis of the acute stroke syndrome. Quar J Med, New Series LII 1983;208:515-523.

130. Bamford J, Sandercock P, Jones L, Warlow C. The natural history of lacunar infarction: The Oxfordshire Community Stroke Project. Stroke 1987;18:545-551.

131. Rankin J. Cerebral vascular accidents in patients over the age of 60: II. Prognosis. Scott Med J 1957;2:200-215.

132. Grassi G, Cattaneo BM, Seravalle G, Lanfranchi A, Mancia G. Baroreflex control of sympathetic nerve activity in essential and secondary hypertension. Hypertens 1998;31(part 1):68-72.

133. Terayama Y, Tanahashi N, Fukuuchi Y, Gotoh F. Prognostic value of admission blood pressure in patients with intracerebral hemorrhage. Stroke 1997;28:11851188 .

134. Sulter G, Steen C, De Keyser J. Use of the Barthel Index and Modified Rankin Scale in acute stroke trials. Stroke 1999;30:1538-1541.

135. de Haan R, Limburg M, Bossuyt P, van der Meulen JHP, Aaronson N. The clinical meaning of Rankin "handicap" grades after stroke. Stroke 1995;26:20272030.

136. Chau NP, Safar ME, Weiss YA, London GM, Simon AC, Milliez PL. Relationships between cardiac output, heart rate and blood volume in essential hypertension. Clin Sci Mol Med 1978;54:175-180.

137. Lip GYH, Gibbs CR, Beevers DG. Ambulatory blood pressure monitoring and stroke: more questions than answers. Stroke 1998;29:1495-1497.

138. Lodder J. Neuroprotection in stroke. Analysis of failure, and alternative strategies. Neurosci Res Com 2000;26(3):173-179.

139. Steingart A, Hachinski VC, Lau C, Fox AJ, Diaz F, Cape R, Lee D, Inzitari D, Merskey H. Cognitive and neurologic findings in subjects with diffuse white matter lucencies on computed tomographic scan (leuko-araiosis). Arch Neurol 1987; $44: 32-35$.

140. Côté R, Hachinski VC, Shurvell BL, Norris JW, Wolfson C. The Canadian Neurological Scale: a preliminary study in acute stroke. Stroke 1986;17:731-737.

141. Van Zagten M, Boiten J, Kessels F, Lodder J. Significant progression of white matter lesions and small deep (lacunar) infarcts in patients with stroke. Arch Neurol 1996;53:650-655.

142. Stergiou GS, Malakos JS, Zourbaki AS, Achimastos AD, Mountokalakis TD. Blood pressure during siesta: effect on 24-h ambulatory blood pressure profiles analysis. J Hum hypertens 1997;11:125-131. 
143. Bursztyn M, Mekler J, Wachtel N, Ben-Ishay D. Siesta and ambulatory blood pressure monitoring, comparability of the afternoon nap and night sleep. Am J Hypertens 1994;7:217-221.

144. Lusardi P, Zoppi A, Preti P, Pesce RM, Piazza E, Fogari R. Effects of insufficient sleep on blood pressure in hypertensive patients. A 24-h study. Am J Hypertens 1999;12:63-68.

145. Baird AE, Austin MC, McKay WJ, Donnan JA. Changes in cerebral tissue perfusion during the first $\mathbf{4 8}$ hours of ischemic stroke:relation to clinical outcome. J Neurol Neurosurg Psych 1996;61:26-29.

146. Lassen NA, Astrup J. Ischemic penumbra. In: Wood JH, editor. Cerebral blood flow. Physiologic and clinical aspects. McGraw-Hill Book Company 1987:458466.

147. Bories J, Derhy S, Chiras J. CT in hemispheric ischaemic attacks. Neuroradiol 1985;27:468-483.

148. Cechetto DF, Wilson JX, Smith KE, Wolski D, Silver MD, Hachinski VC. Autonomic and myocardial changes in middle cerebral artery occlusion: stroke models in the rat. Brain Res 1989;502:296-305.

149. Oppenheimer SM, Wilson JX, Guiraudon C, Cechetto DF. Insular cortex stimulation produces lethal cardiac arrhythmias: a mechanism of sudden death? Brain Res 1991;550:115-121.

150. Smith KE, Hachinski VC, Gibson CJ, Ciriello J. Changes in plasma catecholamine levels after insula damage in experimental stroke. Brain Res 1986;375:182-185.

151. Cheung RTF, Hachinski V. The insula and cerebrogenic sudden death. Arch Neurol 2000;57:1685-1688.

152. Korpelainen JT, Sotaniemi KA, Huikuri HV, Myllylä VV. Circadian rhythm of heart rate variabilty is reversibly abolished in ischemic stroke. Stroke 1997;28:2150-2154.

153. Korpelainen JT, Sotaniemi KA, Mäkikallio A, Huikuri HV, Myllylä VV. Dynamic behaviour of heart rate in ischemic stroke. Stroke 1999;30:1008-1013.

154. Giubilei F, Strano S, Lino S, Calcagnini G, Tisei P, Fiorelli M, Ferretti C, Cerutti S, Fieschi C. Autonomic nervous activity during sleep in middle cerebral artery infarction. Cerebrovasc Dis 1998;8:118-123.

155. Barron SA, Rogovski Z, Hemli J. Autonomic consequences of cerebral hemisphere infarction. Stroke 1994;25:113-116.

156. Naver HK, Blomstrand C, Wallin BG. Reduced heart rate variability after rightsided stroke. Stroke 1996;27:247-251.

157. Tokgözoglu SL, Batur MK, Topçuoglu MA, Saribas O, Kes S, Oto A. Effects of stroke localization on cardiac autonomic balance and sudden death. Stroke 1999;30:1307-1311.

158. Chua HC, Sen S, Cosgriff RF, Gerstenblith G, Beauchamp NJ, Oppenheimer SM. Neurogenic ST depression in stroke. Clin Neurol Neurosurg 1999;101:44-48. 
159. Verdecchia P, Schillaci G, Guerrieri M, Gatteschi C, Benemio G, Boldrini F, Porcellati C. Circadian blood pressure changes and left ventricular hypertrophy in essential hypertension. Circulation 1990;81:528-536. 


\section{Dankwoord}

Dit proefschrift had ik niet kunnen schrijven zonder de hulp van vele anderen. Graag wil ik hierbij speciaal de volgende mensen bedanken:

Mijn co-promotor Dr Jan Lodder. Jan, bedankt dat je mij hebt laten meedelen in jouw wetenschappelijke kennis en ervaring. Mede door jouw gedrevenheid, inzet en enthousiasme heb ik dit proefschrift uiteindelijk met veel plezier geschreven. Ik hoop dat onze samenwerking en vriendschap nog lang mogen voortduren.

Mijn promotor en opleider Prof. dr. Jaap Troost. Bedankt voor het in mij gestelde vertrouwen en de prettige manier waarop ik dit onderzoek heb kunnen voltooien.

Mijn promotor Prof. dr. Peter de Leeuw. Bedankt dat u altijd voor mij klaarstond en mij zeer kritisch en deskundig hebt begeleid bij het schrijven van dit proefschrift.

Fons Kessels. Fons, bedankt voor het geduld waarmee je geprobeerd hebt mij enig inzicht te geven in de statistiek. Je hebt me in ieder geval laten inzien dat denken (soms) helpt!

Lisette van Raak. Door het bijhouden van de 'Maastricht Stroke Registry' weet ik als geen ander hoeveel werk het kost om alle gegevens te verzamelen. Lieve Lisette, ik waardeer het zeer dat ik gebruik heb mogen maken van jouw database.

De verpleegkundigen van afdeling C5. De wijze waarop jullie 3 jaar lang mijn 'bloeddruk-rolletjes' verzameld hebben vraagt heel veel dank. Zonder jullie had dit boekje er waarschijnlijk niet gelegen.

Alle patiënten voor hun medewerking.

De medewerkers van het medisch- en het röntgenarchief. Dank voor jullie snelle en vriendelijke service. Zelfs als ik weer eens dezelfde statussen of foto's kwam halen, bleven jullie behulpzaam.

De neurologen en arts-assistenten van de vakgroep neurologie. Bedankt voor jullie belangstelling, steun en vriendschap. Ik vind het heerlijk om met jullie te mogen samenwerken.

Mijn paranimfen Jean-Paul Glaser en Monique Keulen. Lieve Jompie en Monique, ik ben blij dat jullie straks naast me staan.

Tot slot mijn ouders. Lieve pap en mam, bedankt voor jullie liefde en steun. Dit boekje is voor jullie. 


\section{Curriculum Vitae}

Anita Boreas werd geboren op 4 januari 1969. In 1987 deed ze eindexamen VWO aan het St-Janscollege te Hoensbroek. Hierna studeerde ze Geneeskunde aan de Rijksuniversiteit Limburg (nu Universiteit Maastricht), alwaar ze op 7 februari 1994 haar artsexamen behaalde. Direct aansluitend begon ze als agnio bij de vakgroep Neurologie in het Academisch Ziekenhuis Maastricht. In deze fase werd een aanvang gemaakt met dit onderzoek. Op 1 september 1996 kwam ze als AGIKO Neurologie in opleiding in het Academisch Ziekenhuis Maastricht (opleider Prof. dr. J. Troost) en kon het onderzoek worden voortgezet onder leiding van Prof. dr. P.W. de Leeuw en Prof. dr. J. Troost. De opleiding Neurologie zal begin 2005 worden afgerond. 
ISBN 9090147799 